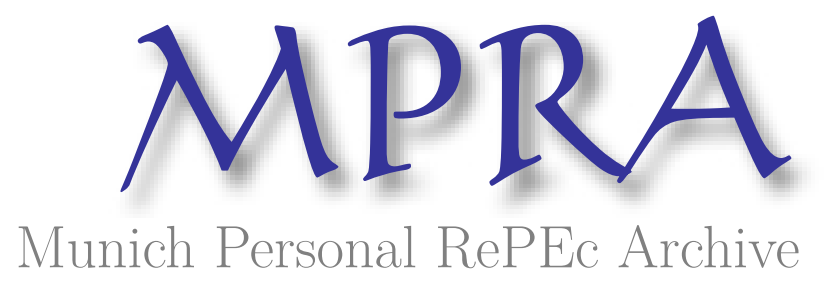

\title{
Managing the Impossible Trinity: Volatile Capital Flows and Indian Monetary Policy
}

\author{
Mohan, Rakesh and Kapur, Muneesh
}

November 2009

Online at https://mpra.ub.uni-muenchen.de/70632/

MPRA Paper No. 70632, posted 14 Apr 2016 06:49 UTC 


\section{Stanford}

Working Paper No. 401

Managing the Impossible Trinity:

Volatile Capital Flows and Indian Monetary Policy

by

\section{Rakesh Mohan}

Muneesh Kapur

November 2009

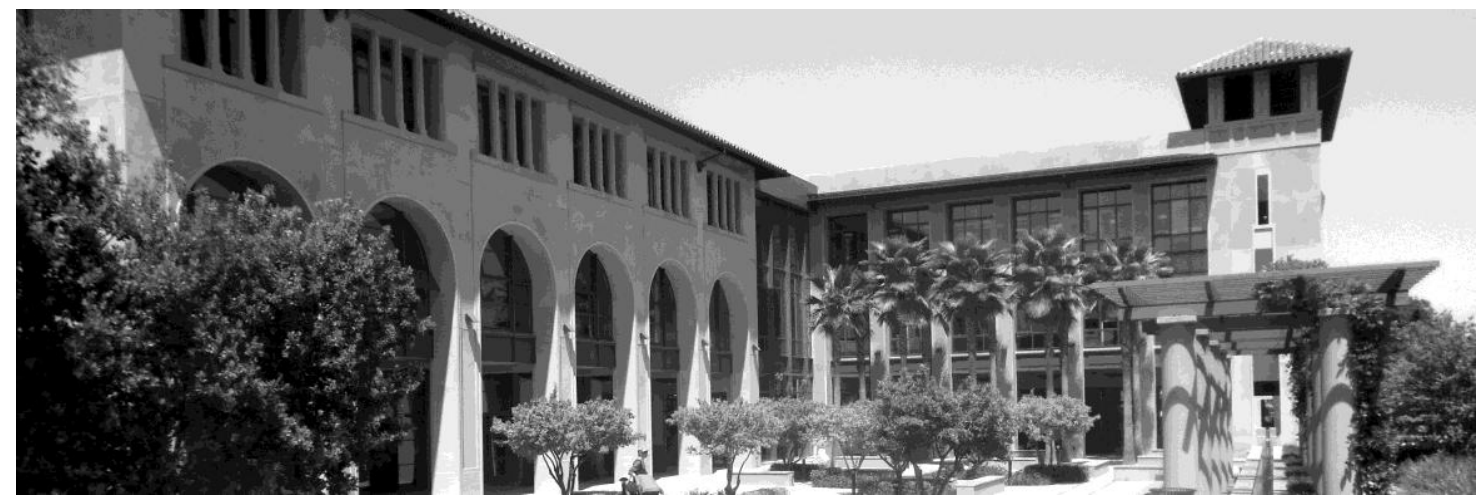

Stanford University

579 Serra Mall @ Galvez, Landau Economics Building, Room 153

Stanford, CA 94305-6015 


\section{CONTENTS}

$\begin{array}{lr}\text { ABSTRACT } & 3\end{array}$

I. INTRODUCTION

$\begin{array}{lr}\text { The Impossible Trinity } & 7\end{array}$

Capital Flow Volatility, Exchange Rate and Monetary Policy 8

II. MANAGEMENT OF THE EXTERNAL ACCOUNT IN INDIA 14

$\begin{array}{ll}\text { The Policy Framework } & 14\end{array}$

Management of Debt Flows 16

External Commercial Borrowing by Non-financial Corporate Entities 18

External Borrowing by Financial Intermediaries and Banks 23

Non-Resident Deposits

Exchange Rate Management and Foreign Exchange Reserves $\quad 27$

How Open is the Indian Economy?

Trends in Net Capital Inflows 38

Efficacy of Capital Account Management $\quad 39$

Net Capital Flows to India: Cross-Country Perspective 42

III. MONETARY MANAGEMENT IN THE FACE OF CAPITAL FLOW 44 VOLATILITY

Monetary Policy: Framework, Objectives and Instruments 44

$\begin{array}{ll}\text { Sterilisation Operations } & 46\end{array}$

$\begin{array}{ll}\text { Liquidity Management } & 49\end{array}$

Transmission to Money Market Rates $\quad 56$

$\begin{array}{ll}\text { Prudential Regulation and Financial Stability } & 58\end{array}$ 
Development and Regulation of Financial Markets

IV. OUTCOMES: WAS MONETARY POLICY INDEPENDENT? 65

Reserve Money, Credit and Money Supply 65

Reserve Money and CRR: Analytics $\quad 68$

Financial Sector Development: Growth with Enhanced Efficiency and Stability $\quad 70$

Money Supply, Credit and Inflation: Cross-Country Comparisons 72

$\begin{array}{ll}\text { Inflation } & 76\end{array}$

$\begin{array}{ll}\text { Output Growth } & 79\end{array}$

Monetary Policy Independence $\quad 82$

V. CONCLUDING OBSERVATIONS 85

$\begin{array}{ll}\text { REFERENCES } & 89\end{array}$

ANNEXES

Annex 1: Exchange Rates and Current Account Balance: Cross-Country Analysis 93

Annex 2: Determinants of Non-Resident Deposit Inflows 96

Annex 3: Chinn-Ito Indices of Financial Openness 99

$\begin{array}{ll}\text { Annex 4: Capital Flows (net): Country-wise } & 100\end{array}$

Annex 5: Supervisory Responsibilities: Cross-Country Practices 101

Annex 6: Financial Crisis and Impact on Growth 103 


\title{
MANAGING THE IMPOSSIBLE TRINITY: Volatile CaPital Flows ANd Indian MONETARy PoliCy
}

\author{
Rakesh Mohan $^{*}$ and Muneesh Kapur ${ }^{\dagger}$
}

November 2009

\begin{abstract}
Large capital inflows are often associated with subsequent credit and investment booms, inflation, overheating, real exchange rate misalignments, current account imbalances and financial sector weaknesses culminating in financial crisis, and long-lasting output losses. India too has received large and volatile capital flows since 1993-94, especially during 2004-09. Nonetheless, macroeconomic, price and financial stability has been maintained in an environment of high growth. What explains these desirable outcomes in India?

An assessment of external sector and monetary management policies adopted by India since the early 1990s, undertaken in this paper, suggests that the outcomes can be attributed to a judicious use of menu of options. These have included: active management of the capital account, especially debt flows; within debt flows, tighter prudential restrictions on access of financial intermediaries to external borrowings vis-a-vis nonfinancial corporate entities; flexibility in exchange rate movements but with capacity to intervene in times of excessive volatility along with appropriate sterilisation of interventions; associated building up of adequate reserves; continuous development of financial markets in terms of participants and instruments; strengthening of the financial sector through prudential regulation while also enhancing competition; pre-emptive tightening of prudential norms in case of sectors witnessing very high credit growth; and refinements in the institutional framework for monetary policy.

As a result of this approach, growth in monetary and credit aggregates could be contained consistent with the real economy undergoing growth, structural transformation and financial deepening. Inflation was contained even as growth accelerated. Overall, financial stability was maintained even as the global economic environment was characterised by a series of financial crises. The impossible trinity was managed by preferring middle solutions of open but managed capital account and flexible exchange rate but with management of volatility. Rather than relying on a single instrument, many instruments have been used in coordination. This was enabled by the fact that both monetary policy and regulation of banks and other financial institutions and key financial markets are under the jurisdiction of the Reserve Bank, which permitted smooth use of various policy instruments. Key lessons from the Indian experience are that monetary policy needs to move away from narrow price stability/inflation targeting objective. Given the volatility and the need to ensure broader stability of the financial system, central banks need multiple instruments. Capital account management has to be countercyclical, just as is the case monetary and fiscal policies. Judgements in capital account management are no more complex than those made in monetary management.
\end{abstract}

Keywords: Capital flows; capital account management; Indian monetary policy.

JEL Classification No.: E44, E52, E58.

\footnotetext{
* Distinguished Consulting Professor, Stanford Centre for International Development, Stanford University and former Deputy Governor, Reserve Bank of India

${ }^{\dagger}$ Director, Special Studies Unit, Department of Economic Analysis and Policy, Reserve Bank of India.

${ }^{*}$ Paper prepared for the Tenth Annual Conference on Indian Economic Policy Reform organized by the Stanford Centre for International Development, Stanford University at Stanford, October 22-23, 2009.

Views expressed in the paper are personal and do not necessarily represent those of the Reserve Bank of India.
} 


\section{MANAGING THE IMPOSSIBLE TRINITY: VOLATILE CAPITAL FLOWS AND INDIAN MONETARY POLICY* \\ Rakesh Mohan ${ }^{1}$ and Muneesh Kapur ${ }^{2}$}

\section{INTRODUCTION}

The conduct of monetary policy in India has seen a significant transformation since the early 1990s. The period prior to that was characterised by fiscal dominance and associated financial repression. That, inter alia, necessitated administered interest rates, large statutory pre-emptions for financing the fiscal requirements, and sectoral credit targets. Since the early 1990s, the overall economic environment has changed substantially from that of a tightly controlled and regulated economy to one benefitting from a growing degree of deregulation and liberalisation, both domestic and external. Fiscal dominance has given way to monetary-fiscal coordination on the back of fiscal responsibility legislations and other complementary reforms. Statutory pre-emptions have seen significant reduction; interest rates have been deregulated, although still not fully; financial markets have seen progressive deepening,

* Paper prepared for the Tenth Annual Conference on Indian Economic Policy Reform organized by the Stanford Centre for International Development, Stanford University at Stanford, October 22-23, 2009.

1 Distinguished Consulting Professor, Stanford Centre for International Development, Stanford University and former Deputy Governor, Reserve Bank of India

${ }^{2}$ Director, Special Studies Unit, Department of Economic Analysis and Policy, Reserve Bank of India.

Views expressed in the paper are personal and do not necessarily represent those of the Reserve Bank of India. 
widening and integration over the years; the external sector has witnessed significant liberalisation - the current account became convertible in 1994 and the exchange rate has been largely market-determined since March 1993. The capital account has been progressively liberalised in terms of inflows as well as outflows. Monetary policy signals are now largely transmitted through changes in policy rates. Legislative amendments have been undertaken to provide RBI greater leeway in its monetary operations.

The various reforms that have taken place since the early 1990s have thus provided greater flexibility to monetary policy in its conduct and operations. At the same time, monetary policy has had to grapple with new challenges beginning 1993-94 from large and growing, but volatile capital flows. These challenges have grown markedly since 2003-04 on the back of a large jump in net capital flows, which reached a peak of almost 9 per cent of GDP in 2007-08 - much above the current account deficit. In the very next year (2008-09), as a consequence of the global financial crisis, capital flows slumped to 0.8 per cent of GDP - and fell short of the current account deficit, which itself widened. During 2007, India was the highest recipient of net capital flows amongst all EMEs and the third highest globally (after US and Spain).

Large capital inflows are often associated with subsequent credit and investment booms, inflation, overheating, real exchange rate misalignments, current account imbalances and financial sector weaknesses culminating in financial crisis. Reversals of capital flows to the EMEs are often quick, as again shown by the current financial crisis, necessitating a painful adjustment in bank credit, collapse of asset prices, compression of domestic demand and output losses. Thus, the boom and bust pattern of capital inflows can, unless managed proactively, result in large employment and output losses, and macroeconomic and financial instability. On account of such a boom and bust pattern, since the mid- 
1990s many EMEs and regions - Mexico in 1994-95, Asia in 1997, Russia in 1998, Argentina in 2001, and Emerging Europe in the ongoing financial crisis - have suffered financial crises. "Financial crises are more frequent than most people think, and they lead to losses that are much larger than one would hope. On average, there have been between three and four systemic banking crises per year for the past quarter century" (Cecchetti, Kohler and Upper, 2009). In a sample of 40 financial crises, these authors found that fully one fourth resulted in cumulative output losses of more than 25 per cent of pre-crisis GDP. And one third of the crisis-related contractions lasted for three years or more. Whereas crises in the recent past have largely been associated with EMEs and developing countries, the current crisis is that of advanced countries. In their case also, it is the expansion of global financial imbalances that has been among the major causes.

Against the above backdrop of recurrent crises and large losses, it is noteworthy that, despite the large volume of capital inflows and outflows, macroeconomic and financial stability has been maintained in India and most other EMEs over the past decade or so. Thus, even as financial crises have been rampant across the globe, financial excesses have been successfully contained in India and other EMEs even in the face of large capital inflows and outflows.

How has India managed capital flows of such an order and still ensured high growth and financial stability? While theory commonly suggests that the combination of an open capital account, a fixed exchange rate and an independent monetary policy - "impossible trinity" or "macroeconomic policy trilemma" - is not possible, most emerging market economies have managed their way out of this impossible trinity by moving away from the hard corners to middle solutions. India too has managed the impossible trinity over the past couple of decades and the 
outcomes have been satisfactory. How has the policy trilemma been managed? These are the issues that are addressed in this paper.

\section{The Impossible Trinity}

It is an accepted tenet of open economy macroeconomics that the combination of an open capital account, a fixed exchange rate and an independent monetary policy - the "impossible trinity" - is not feasible. Countries can attain any two of these three objectives but not all the three simultaneously. Thus, with an open capital account and a fixed exchange rate, an independent monetary policy is not possible. On the other hand, the pursuit of an independent monetary policy will require a country to accept either a closed capital account or a flexible exchange rate, but not both.

As countries have opened their external accounts, both current and capital accounts, and as the Bretton Woods system broke down, it has been generally accepted that the operation of an independent monetary policy necessitated the operation of fully open capital accounts and floating exchange rates. This has been the general macroeconomic and monetary policy regime followed by advanced countries.

The practice followed by emerging market economies (EMEs) and other developing countries has, however, been different in recent years. Whereas the theory appears to restrict the choice to the hard corners of policy, it does not seem to have dealt with the possibility of operating in the middle. With the experience gained from the Latin American debt crisis of the 1980s and 1990s, and that of the Asian crisis in the late 1990s, most Asian and Latin American EMEs have eschewed both closed capital accounts and fixed exchange rates, as has India. However, in

most cases, they have practised different degrees of management of the capital account, while keeping it relatively open; and have also practised 
managed floats of the exchange rate implying considerable flexibility but not a free float or a fixed exchange rate. This practice has enabled them to retain monetary independence and in that sense managed the "impossible trinity." The actual conduct of policy reflects recognition of the actual costs and benefits of a fully open versus managed capital accounts and of a completely floating exchange rate versus a managed but flexible exchange rate. India's macroeconomic, monetary and external account management has very clearly been of this genre.

Why have EMEs followed this particular direction in policy?

\section{Capital Flow Volatility, Exchange Rate and Monetary Policy}

A key area of concern and vulnerability for EMEs is on account of volatility in capital flows. Surges in capital flows are often followed by sudden stops. This volatility is often the consequence of monetary policy stance and other developments in advanced economies, unrelated to those in EMEs. Low interest rates in advanced economies encourage outflows from these economies into EMEs in search of yields and vice versa. Thus, interest rate cycles can generate cycles in capital flows to the EMEs (CGFS, 2009). In the ongoing financial crisis, EMEs have suffered despite the existence of strong domestic fundamentals. This is reflected in large projected capital outflows from EMEs in 2009 in contrast to record high inflows just two years earlier. Net private capital flows are projected to swing from inflows of US $\$ 617$ billion in 2007 to outflows of US $\$ 190$ billion in 2009 - a turnaround of 5.5 per cent of EMEs' GDP (Table 1). Such a fast turnaround in capital flows, if not managed actively by policy authorities, has serious consequences for the domestic economy and overall financial stability. This has again brought home very starkly in the latest episode of sub-prime financial turmoil. 
Table 1: Capital Flows (net) to Emerging and Developing Economies

\begin{tabular}{|c|c|c|c|c|c|c|c|}
\hline Item & 1980s & $1990-96$ & 1997-02 & 2003-06 & 2007 & 2008 & 2009 \\
\hline 1 & 2 & 3 & 4 & 5 & 6 & 7 & 8 \\
\hline \multicolumn{8}{|c|}{ Amount in US $\$$ billion } \\
\hline Current account balance & -28 & -83 & 4 & 364 & 633 & 714 & 262 \\
\hline Private capital flows, net & 8 & 124 & 86 & 201 & 617 & 109 & -190 \\
\hline Direct investment, net & 12 & 61 & 161 & 208 & 359 & 459 & 313 \\
\hline Private portfolio flows, net & 6 & 65 & 2 & -25 & 39 & -155 & -235 \\
\hline Other private capital flows, net & -9 & -2 & -77 & 19 & 219 & -195 & -268 \\
\hline Official flows, net & n.a. & -13 & 8 & -90 & -101 & -60 & 58 \\
\hline Change in reserves & -10 & -58 & -114 & -550 & -1258 & -866 & -266 \\
\hline \multicolumn{8}{|c|}{ Per cent to GDP } \\
\hline Current account balance & -0.7 & -1.7 & 0.0 & 3.4 & 4.1 & 3.8 & 1.6 \\
\hline Private capital flows, net & 0.2 & 2.5 & 1.4 & 2.1 & 4.0 & 0.6 & -1.1 \\
\hline Direct investment, net & 0.3 & 1.2 & 2.6 & 2.1 & 2.3 & 2.5 & 1.9 \\
\hline Private portfolio flows, net & 0.1 & 1.3 & 0.1 & -0.2 & 0.3 & -0.8 & -1.4 \\
\hline Other private capital flows, net & -0.2 & -0.1 & -1.3 & 0.2 & 1.4 & -1.0 & -1.6 \\
\hline Official flows, net & n.a. & -0.2 & 0.1 & -0.9 & -0.7 & -0.3 & 0.3 \\
\hline Change in reserves & -0.3 & -1.2 & -1.8 & -5.5 & -8.2 & -4.7 & -1.6 \\
\hline
\end{tabular}

Notes:

1. Data in columns 2 to 5 are annual averages for the respective periods.

2. Data for 2009 in column 8 are IMF projections.

3. -ve sign in "change in reserves" denotes increase in reserves.

4. n.a.: not available.

Source: World Economic Outlook Database (April 2009), IMF.

While there has been a sharp expansion in the volume and volatility of net capital flows, there has been an even more significant growth in underlying gross inflows and outflows (CGFS, 2009). Private capital inflows (net) by non-residents to all EMEs, taken together, jumped from an annual average of US $\$ 200$ billion during 1998-2000 to US $\$ 800$ billion in 2003-06 and further to US $\$ 2,100$ billion in 2007, but slumped to US $\$$ 750 billion in 2008. Over the same periods, private capital outflows by residents from the EMEs amounted to US $\$ 100$ billion, US $\$ 600$ billion, US $\$ 1,500$ billion and US $\$ 650$ billion, respectively (World Economic Outlook, April 2009, IMF). Inflows and outflows thus collapsed by almost two-thirds during 2008. It is these inflows and outflows that have greater 
impact on daily exchange rate movements and expectations relative to net flows. They are often more important from policymakers' point of view. Gross inflows and outflows of capital are also relevant in the context of the recent global credit bubble. "To understand the phenomenon of the global credit bubble, however, gross capital flows are far more important than net capital flows. The gross capital flows do not necessarily correspond to the savings-investment balances at a national and regional level. In fact, it was euro area banks that strikingly expanded cross-border lending, while the euro area as a whole did not register a current account surplus" (Shirakawa, 2009).

Large volatility in capital flows, as being witnessed currently, has implications for domestic monetary and liquidity conditions in the EMEs. Sudden and substantial exchange rate movements constitute an important channel through which capital flows can potentially have an adverse impact on the domestic economy. The impact of exchange rate changes on the real sector is significantly different for developing countries as compared with that for reserve currency countries. For the former which specialise in technology intensive products, the degree of exchange rate pass through is low, enabling exporters and importers to ignore temporary shocks and set stable product prices despite large currency fluctuations. Moreover, mature and well developed financial markets in these countries help to absorb the risk associated with exchange rate fluctuations with negligible spillover on the real activity. On the other hand, for the majority of developing countries and EMEs, which specialise in labour-intensive and low and intermediate technology products, profit margins in the intensely competitive markets for these products are very thin and vulnerable to pricing power by large retail chains. Consequently, exchange rate volatility has significant employment, output and distributional consequences (Mohan, 2004). These observations are supported by 
empirical evidence contained in Aghion, Bacchetta, Ranciere and Rogoff (2009). The paper finds that, in countries with less developed financial sectors, exchange rate volatility has a significant negative impact on productivity growth; the effects are, however, small or insignificant in countries with developed financial systems.

In view of adverse implications of exchange rate volatility on macroeconomic performance, how should central banks/ monetary policy react to exchange rates? The conventional view is that policy interest rates should respond primarily to inflation and real GDP and not to exchange rate movements. Such recommendations are based on models that "are globalised: they assume perfect capital mobility between countries, interdependence of foreign exchange markets, price links between different countries, as well as export and import flows and the current account" and in these models "an increase in the trade deficit will tend to lead to a depreciation of the currency" (Taylor, 2008). However, from the perspective of emerging market economies, such recommendations/models are perhaps not appropriate. In the current state-of-the-art macro models, there is no room "for such things as bubbles and banking-system collapse" (Krugman, 2009).

In the models, as noted by Taylor (op cit.) trade deficits lead to currency depreciation. What is the actual global experience on this issue? It is interesting that, contrary to what might be expected, a simple analysis of current account balance and exchange rates for a sample of 36 countries indicates that current account deficits are associated with both nominal and real appreciation (Annex 1). Thus, at least in the current decade, countries with large current account deficits have surprisingly experienced a tendency for their exchange rates to appreciate, which can have significant deleterious effects on their real economies. 
With open capital accounts and rapid movement of capital flows it is these flows that dominate the effect of current account deficits and drive exchange rate dynamics. Corrections do take place, but these are with substantial lags and often end up in crisis. The conventional models, it is apparent, are focussed on implications of exchange rates on price stability. But, as the current global financial crisis has shown, price stability does not guarantee financial stability. Exchange rate dynamics in an open capital account run the risk of creating financial fragilities. Thus, there seems to be an important role for policy authorities, not necessarily through interest rates, to ensure that large real exchange rate misalignments do not persist for long periods. This involves active capital account management, intervention and sterilisation, along with continuous strengthening of financial sector.

With the increase in cross border capital flows, the exchange rate appears to be influenced more by these flows rather than developments in the current account, which perhaps reflects economic fundamentals better. Since capital flows are much more volatile than current account developments, subject to herd behaviour leading to excess flows and sudden stops, EMEs have had to resort to some degree of capital account management and associated forex interventions influencing movements in the exchange rate.

The Indian experience with respect to overall macro management has been broadly similar to that of other EMEs in Asia and Latin America over the past decade. It has also eschewed corner solutions in exchange rate and capital account management while practicing an independent monetary policy. Against this backdrop, in the next section an analytical assessment is made of management of the external sector in India since the early 1990s, with particular focus on management of the capital account and exchange rate. Efficacy of capital controls is critically 
assessed. How monetary management was conducted in the context of volatile capital flows is then presented in Section III. The monetary policy framework employed, the mode of liquidity management and the range of sterilisation instruments/operations used are discussed in this section. This also includes a discussion of the prudential measures used to supplement monetary policy so as to manage the impossible trinity and ensure financial stability. Section IV undertakes an assessment of the outcomes in terms of key monetary and macroeconomic variables - credit, money supply, financial sector health, inflation and growth. The outcomes in the Indian context are compared with those in other economies. Key lessons from the Indian experience are set out in the concluding section. 


\section{MANAGEMENT OF THE EXTERNAL ACCOUNT IN INDIA}

\section{The Policy Framework}

External sector policy has witnessed very significant changes as part of the overall economic reforms practiced in India since the early 1990s. The economy has been opened substantially over this period from its relatively closed stance earlier. The hallmark of policy has, however, been that of gradualism.

The current account was gradually liberalised over the decade of the 1990s with the elimination of quantitative trade restrictions and gradual reduction of tariffs, which are now close to ASEAN levels. Current account convertibility obligations under Article VIII of the IMF were accepted in 1994. Capital account liberalisation has been more gradual. It has been seen as a continuous process, rather than as a one-off event, contingent upon the progress in fiscal consolidation, and in financial sector and real sector reforms. This policy stance has been adopted since the early 1990s, when capital account liberalisation was being recommended strongly as a goal. It was only subsequent to the Asian Financial Crisis that more caution has crept into the international approach to full capital account opening.

In its approach to opening of the capital account, India has clearly recognized a hierarchy in capital flows. It has favoured equity flows over debt flows and foreign direct investment over portfolio investment. The Indian capital market has been opened to institutional portfolio flows, but with some limits on shares of domestic companies that can be held by foreign portfolio investors, both individually and collectively ${ }^{3}$. Apart from

\footnotetext{
${ }^{3}$ Total shareholding of each FIl/sub-account shall not exceed 10 per cent of the total paid-up capital, while total holdings of all Flls /sub-accounts put together
} 
some limits on proportion of equity held by non residents in certain sensitive sectors, FDI is now almost fully open.

A more cautious approach has been followed with regard to debt flows. Portfolio investment in both corporate and government debt are governed by overall quantitative limits; the access of the nonfinancial corporate sector to external debt has been liberalised gradually, but is subject to adherence to criteria related to purpose, interest rate spreads and magnitudes of borrowing. These controls have been modified from time to time depending on the volume of capital flows. The access of financial sector intermediaries has been subject to more prudential restrictions in recognition of the greater hazards associated with such external borrowing.

Capital outflows have also been liberalised progressively. All inflows by non residents are freely repatriable. Resident non-financial companies have been enabled to invest abroad relatively freely with few restrictions. Individuals can also invest abroad but within specified quantitative limits. Individuals are, however, not permitted to borrow abroad.

It is often argued that deep financial markets help in channelling large and volatile capital flows efficiently. If capital flows reach levels as high as 9 per cent of GDP, as they did in India in 2007-08, it is debatable that even a highly advanced financial system can intermediate such capital flows efficiently and in a stable manner. For such a large volume of capital flows to be fully absorbed, an equivalent current account deficit or large real appreciation or a combination thereof would be the immediate consequence. These outcomes would in turn be manifested in asset price

shall not exceed 24 per cent of the paid-up capital. The limit of 24 per cent can be increased to the sectoral cap/statutory limit, as applicable to the Indian company concerned, by passing a resolution of its Board of Directors followed by a special resolution to that effect by its General Body. 
and credit booms and financial imbalances. All these options are clearly unsustainable and can lead to future fragility as revealed by the developments in some Asian economies during the Asian financial crisis of 1997 and in East European nations and the Baltics in the current global financial crisis. However, in 2007-08 the Indian current account deficit did increase to (-)1.5 percent of GDP, the highest level since 1995-96, and the real exchange rate appreciated by 13.4 per cent between August 2006 and October 2007.

Accordingly, in India, a multi-pronged approach has been pursued to manage the volatility emanating from capital flows. These include: calibrating the policy regime in regard to the debt component of capital inflows/outflows, distinction between financial intermediaries and other resident entities, liberalisation of policies in regard to capital outflows, flexibility in exchange rate movements, and interventions to smoothen volatility. Forex market interventions are sterilised through modulations in cash reserve requirement, and open market operations (including through issuances of government securities under the market stabilisation scheme (MSS)). Repo/reverse operations under the daily liquidity adjustment facility (LAF) also help to modulate liquidity. Prudential tools have been judiciously used to supplement monetary measures to contain financial excesses. More generally, prudential financial sector regulation has supplemented capital account management to ensure resilience of the domestic economy.

\section{Management of Debt Flows}

Debt flows - foreign borrowings by corporate entities, foreign investment in domestic debt securities (both government and corporate) and banks' access to foreign borrowings - are subject to prudential 
controls through a system of overall ceilings on the amounts that can be borrowed, maturity prescriptions and ceilings on interest rate spreads. The underlying rationale for this approach reflects the fact both inflation and growth in India are higher than those prevailing in the advanced economies. Accordingly, nominal interest rates are also higher in India and these differentials could continue over the foreseeable future in view of robust growth prospects of the Indian economy. In theory, in terms of uncovered interest parity (UIP), interest rate differentials should be offset by currency movements. However, the empirical evidence in favour of UIP is weak. Hence, an open policy regime in regard to debt flows can attract large hot money on account of not only interest rate differentials but also exchange rate expectations which then become self fulfilling for a period of time, attracting further arbitrage flows, before an ultimate reversal. It is, therefore, appropriate to have prudential policies on debt flows to avoid such instability in both the exchange rate and in capital flows. In order to aid the management of debt flows as part of overall capital flow management, the extant prudential policies at any given time are modulated depending on the circumstances. They are tightened during times of large capital inflows and liberalised when reversal takes place as happened in 2008-09.

In particular, foreign investment in government securities is subject to overall ceilings (US $\$ 5.0$ billion at present) (Table 2). Fiscal deficits in India remain high and these have increased further due to fiscal stimuli measures necessitated by the global financial crisis. Historically, fiscal deficits in India have been financed almost wholly through domestic sources (except for a small part through official aid). This domestic financing has minimised India's vulnerabilities to crises, which have been very frequent elsewhere. Indeed, in the current global financial crisis, the absence of any sovereign issue in the international markets for financing 
the deficit of the Government helped in limiting the effects of adverse external shocks on the macroeconomic policy environment of the country. Reflecting proactive management of liquidity by the Reserve Bank, domestic financial markets were able to absorb even the trebling in market borrowings during 2008-09. As in the case of government securities, investment by non-residents in local corporate bonds is subject to overall ceilings (at present US \$ 15 billion) (Table 2).

Table 2: Ceilings on Investments by Foreign Institutional Investors (FIIs) in Debt Instruments

(US \$ billion)

\begin{tabular}{lclc}
\hline \multicolumn{2}{c}{ Government Securities } & \multicolumn{2}{c}{ Corporate Debt Securities } \\
Date & Ceiling & \multicolumn{1}{c}{ Date } & Ceiling \\
\hline 1 & 2 & \multicolumn{1}{c}{3} & 4 \\
\hline April 1998 & 1.0 & December 2, 2004 & 0.5 \\
November 2, 2004 & 1.75 & April 5, 2006 & 1.5 \\
April 5, 2006 & 2.0 & June 6, 2008 & 3.0 \\
January 19, 2007 & 2.6 & October 16, 2008 & 6.0 \\
January 31, 2008 & 3.2 & January 2, 2009 & 15.0 \\
June 6, 2008 & 5.0 & & \\
\hline
\end{tabular}

\section{External Commercial Borrowing by Non-financial Corporate Entities}

The policy on external commercial borrowing by non-financial corporate entities is informed by the need to encourage private investment for growth. Providing creditworthy entities access to international capital markets helps in providing competition to domestic financial institutions apart from enhancing their own access to resources for investment purposes Thus external commercial borrowings (ECBs) are permitted for investment (such as import of capital goods, new projects, 
modernization/expansion of existing production units) in the real sector (industrial sector including small and medium enterprises, infrastructure sector and specific service sectors) as well as for overseas direct investment. On prudential grounds, ECB is, however, not permitted for (a) on-lending or investment in the capital market or for acquiring a company in India (b) investment in the real estate sector and (c) working capital, general corporate purpose and repayment of existing Rupee loans. Subject to these general guidelines, borrowings up to specified limits and maturity requirements do not need any prior permission. The "automatic" route was operationalised in 2000 for ECB up to US \$50 million with minimum average maturity of three years, and then, on the basis of experience gained, liberalised substantially subsequently, to US \$500 million (per borrowing company per financial year) in January 2004 for ECBs with minimum average maturity of five years. In addition, US \$250 million was permitted, effective December 2006, for borrowings with minimum average maturity of ten years. ECBs beyond these limits are subject to prior approval. Discretionary approvals for other purposes and beyond these individual ceilings are guided by the extant macro limits on total ECB that are prescribed for each financial year.

In view of the large jump in capital flows during 2006-07 and 2007-08, the policy regime was tightened in 2007 in phases. First, in May 2007, the 'all-in-cost' ceilings were tightened by $50-100$ basis points (Table 3 ). Second, in August 2007 all ECBs above US \$ 20 million were permitted only for foreign currency expenditure purposes (thus, use of ECBs for rupee expenditures was restricted). Unused proceeds were required to be parked overseas and could not be remitted to India. Finally, taking in to account the sharp growth in asset prices, especially property prices, the use of ECBs for development of integrated townships was also prohibited (in addition to the existing ban on use for real estate). 
Table 3: Management of External Commercial Borrowings

(All-in-cost ceilings over 6-months LIBOR in basis points)

\begin{tabular}{lrrr}
\hline Date & \multicolumn{3}{c}{ Minimum Average Maturity } \\
\cline { 2 - 4 } & $\begin{array}{r}\text { More than 3 years } \\
\text { and up to 5 years }\end{array}$ & $\begin{array}{r}\text { More than 5 years } \\
\text { and up to 7 years }\end{array}$ & $\begin{array}{r}\text { More than 7 } \\
\text { years }\end{array}$ \\
\hline 1 & 2 & 3 & 4 \\
\hline January 31, 2004 & 200 & 350 & 350 \\
May 21, 2007 & 150 & 250 & 250 \\
May 29, 2008 & 200 & 350 & 350 \\
September 22, 2008 & 200 & 350 & 450 \\
October 22, 2008 & 300 & 500 & 500 \\
January 2, 2009 & $*$ & $*$ & $*$ \\
\hline
\end{tabular}

Note:

All-in-cost ceilings include rate of interest, other fees and expenses in foreign currency (except commitment fee, pre-payment fee, and fees payable in Indian Rupees). Payment of withholding tax in Indian Rupees is also excluded for calculating the all-in-cost.

*: In view of the tightness in international financial markets on the back of the global financial crisis, the extant all-in-cost ceilings were dispensed with up to December 31, 2009. Borrowers proposing to avail of ECBs beyond these ceilings are required to approach $\mathrm{RBI}$ for approval.

Source: Reserve Bank of India.

Following the onset of the sub-prime led global financial crisis and the subsequent tightness in international financial markets, these restrictions were relaxed in a phased manner beginning May $2008^{4}$. Following the collapse of Lehman Brothers, restrictions on use of ECBs for rupee expenditures were withdrawn fully in October 2008. Thus, the policy

\footnotetext{
${ }^{4}$ In May 2008, borrowers in infrastructure sector were permitted to avail ECBs up to USD 100 million for rupee expenditure for permissible end-uses under the Approval Route; for other borrowers, the limit for rupee expenditure under the Approval Route was enhanced to USD 50 million. In September 2008, the limit of USD 100 million for infrastructure borrowers was raised to USD 500 million per financial year under the Approval Route. ECBs in excess of USD 100 million for Rupee expenditure were required to have a minimum average maturity period of 7 years.
} 
framework on ECBs has been actively managed taking into account the relevant factors. Were these measures effective?

Gross drawals under ECBs rose from a quarterly average of US \$1.2 billion during June 2002-September 2004 to US \$ 4.1 billion during September 2005-December 2006 and further to US $\$ 7.2$ billion during March 2007-September 2007. The large increase in ECBs could be attributed to the acceleration in manufacturing GDP growth from 7.0 per cent to 10.0 per cent and 10.2 per cent over the same periods (Chart 1). Monetary tightening by $\mathrm{RBI}$ over the same period in response to demand pressures and incipient signs of overheating also could have made ECBs attractive.

Chart 1

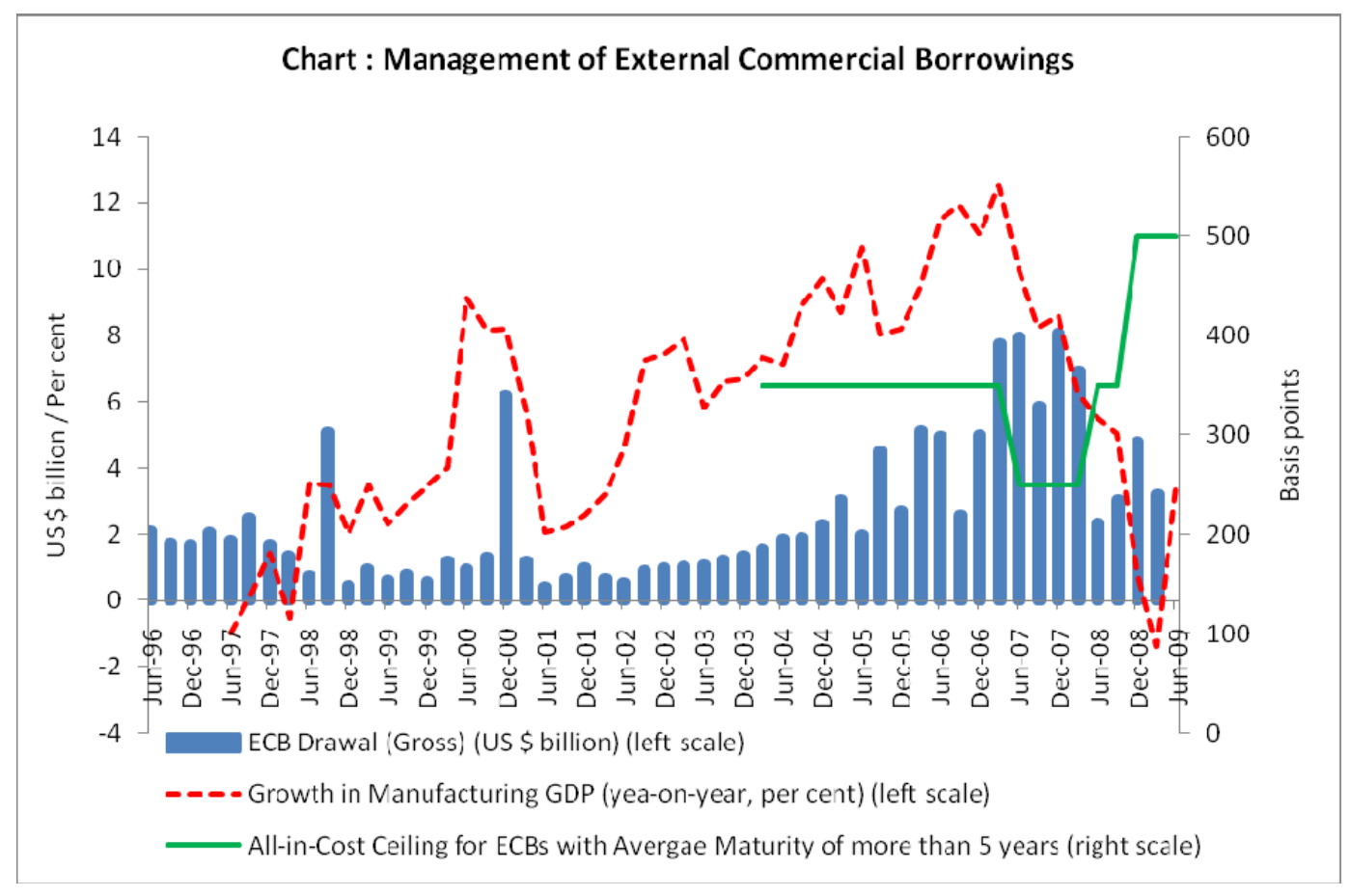


Empirical evidence indicates that the policy framework was effective in achieving a balanced maturity profile as also in channelling funds for investment purposes such as import of capital goods. Reflecting the restrictions on use of ECBs for rupee expenditure, the proportion of borrowings used for import of capital goods increased from around 25 per cent during 2005-06 and 2006-07 to 41 per cent during 2007-08 (Table 4). The share of rupee expenditure fell from around 14 per cent to 3 per cent over the same period. Econometric estimates indicate that long-run demand for overseas commercial borrowings is influenced by the pace of domestic real activity, interest rate differentials between the domestic and international markets and domestic credit conditions. However, real variables dominate price variables in driving the demand for overseas commercial borrowings (Singh, 2007).

Table 4: Utilisation Pattern of External Commercial Borrowings

\begin{tabular}{lrrr}
\hline Item & $\mathbf{2 0 0 5 - 0 6}$ & $\mathbf{2 0 0 6 - 0 7}$ & $\mathbf{2 0 0 7 - 0 8}$ \\
\hline $\mathbf{1}$ & $\mathbf{2}$ & $\mathbf{3}$ & $\mathbf{4}$ \\
\hline 1. Total ECB Registrations (US \$ billion) & 11.5 & 25.4 & 31.0 \\
2. Share in total (Per cent) & & & \\
$\quad$ (a) Import of capital goods & 26.7 & 22.7 & 41.1 \\
$\quad$ (b) Rupee expenditure for local sourcing of capital goods & 16.5 & 12.1 & 2.7 \\
$\quad$ (c) New Projects, and Modernisation/Expansion of & 37.7 & 48.1 & 25.0 \\
$\quad \begin{array}{l}\text { Existing Units } \\
\text { (d) Investment in Joint Ventures Abroad and Wholly }\end{array}$ & 2.3 & 5.5 & 12.6 \\
$\quad$ Owned Subsidiaries & & 11.6 & 18.6 \\
(e) Others & 16.8 & 11.6
\end{tabular}

Source: Singh (2007). 


\section{External Borrowing by Financial Intermediaries and Banks}

An important feature of the ECB policy is the distinction between borrowings by non-financial corporate entities and financial intermediaries, which has been in place since January 2004. Excessive foreign currency borrowings by financial intermediaries can expose them to the risks of both currency and maturity mismatches and can also be associated with unsustainable credit booms. More often, such excesses are followed by busts and severe crisis. Accordingly, access of financial intermediaries (banks, financial institutions, NBFCs, housing finance companies) to ECB, unlike other corporates, is subject to prior approval and for a few specified sectors/purposes. More generally, access of financial intermediaries to $E C B$ is subsumed in a ceiling on their overall external borrowings. At present, banks' overseas foreign currency borrowings (including ECB and loans/overdrafts from their head offices, overseas branches and correspondents) are restricted to 50 per cent of their unimpaired Tier-I Capital or US\$ 10 million, whichever is higher ${ }^{5}$.

The prudent approach in regard to banks' access to ECB is an important component of India's overall approach to banking regulation and capital account management. As a part of financial sector reforms that were initiated in the early 1990s, the prudential framework governing banks, especially commercial banks, was tightened in a phased manner. A Board for Financial Supervision for focussed regulation and supervision of banks and other financial institutions was set up under RBl's jurisdiction. Risk-weights, provisioning norms, income recognition norms and capital adequacy requirements were brought on par with international norms. As of April 2009, all commercial banks are Basel II compliant.

\footnotetext{
${ }^{5}$ Overseas borrowings for export credit in foreign currency, subordinated debt placed by head offices of foreign banks with their branches as Tier II capital and capital funds raised by issue of 'innovative perpetual debt instruments' and 'debt capital instruments' are outside the 50 per cent limit.
} 
While the banking system is dominated by public sector banks, competition has been ensured through new generation private sector banks as well as among public sector banks themselves. With the setting up of private banks, governance norms were strengthened and 'fit and proper' criterion for directors and senior management were also prescribed. Single- and group-exposure norms are in place to reduce concentration risks. A number of measures based on the principles that are now accepted internationally were already brought into practice even before the crisis. These included restrictions on leverage for banking and non banking institutions, stringent liquidity requirements, counter cyclical prudential measures, not recognising in Tier I capital many items that are now sought to be deducted internationally, recognising profits from sale of securitised assets to SPVs over the life of the securities issued, and not reckoning unrealised gains in earnings or in Tier I capital (Thorat, 2009).

\section{Non-Resident Deposits}

A specific feature of Indian banks' external liabilities is the facility provided for deposits by non-resident Indians. This facility is a legacy of the earlier period that was characterised by shortage of foreign exchange resources. At that time, the facility provided for low risk bank deposits at interest rates higher than those available to retail depositors in their host countries. This route was then seen to be easier and cheaper for raising external resources rather than other forms of market borrowing in international capital markets. Incremental deposits are now small relative to ECB but do provide further flexibility in management of the capital account. Whereas these deposits are outside the 50 per cent ceiling noted above for banks, they are subject to prudential interest rate ceiling spreads over LIBOR/swap rates of respective currencies and maturities.

Spreads over LIBOR have ranged between 0 and 250 basis points in the 
case of rupee-denominated deposits (NRERA), where the foreign exchange risk is borne by the depositor. In the case of foreign currency denominated deposits (FCNRB), there is no foreign exchange risk for the depositor and the spread is lower than the rupee deposits; for most part of the current decade, the spread was negative. In order to attract stable deposits and de-emphasise short-term component, minimum maturity of deposits is one year. To manage these debt flows, interest rate ceilings are tightened during episodes of large capital inflows and vice versa (Table 5).

Table 5: Management of Non-Resident Deposits: Interest Rate Ceilings (Spread above LIBOR/swap in basis points)

\begin{tabular}{|c|c|c|c|}
\hline $\begin{array}{l}\text { Non-Resident Ext } \\
\text { Accounts (NRERA) }\end{array}$ & Rupee & $\begin{array}{l}\text { Foreign Currency } \\
\text { Bank (FCNRB) Depc }\end{array}$ & Resident \\
\hline Effective Date & Spread & Effective Date & Spread \\
\hline 1 & 2 & 3 & 4 \\
\hline July 17,2003 & 250 & April 19, 2001 & 0 \\
\hline September 15, 2003 & 100 & April 29, 2002 & $(-25$ \\
\hline October 18, 2003 & 25 & March 28, 2006 & \\
\hline April 17, 2004 & 0 & January 31, 2007 & $(-) 25$ \\
\hline November 1, 2004 & 50 & April 24, 2007 & $(-) 75$ \\
\hline November 17, 2005 & 75 & September 16, 2008 & $(-) 25$ \\
\hline April 18, 2006 & 100 & October 15, 2008 & 25 \\
\hline January 31, 2007 & 50 & November 15, 2008 & 100 \\
\hline April 24, 2007 & 0 & & \\
\hline September 16, 2008 & 50 & & \\
\hline October 15, 2008 & 100 & & \\
\hline November 15,2008 & 175 & & \\
\hline
\end{tabular}

Available empirical evidence suggests that non-resident deposits are influenced by standard risk and return variables, particularly changes in relative interest rates (Gordon and Gupta, 2004). These results are corroborated by the behaviour of non-resident deposits in the current decade. Both NRERA and FCNRB deposit inflows respond, as expected, to changes in deposit ceilings. Higher ceilings are followed by higher inflows and vice versa (Charts 2 and 3). Formal econometric analysis 
supports the above observations. (Annex 2). A reduction of 100 basis points in interest rate ceilings on each of the deposits schemes is associated with a decline of over US $\$ 400$ million in the long-run in both the schemes taken together (around US $\$ 5$ billion per annum) and vice versa. Therefore, the policy modulations in interest rate ceilings appear to have been successful in their objective of having a better control over the volume of inflows under the deposits schemes.

\section{Charts 2 and 3}

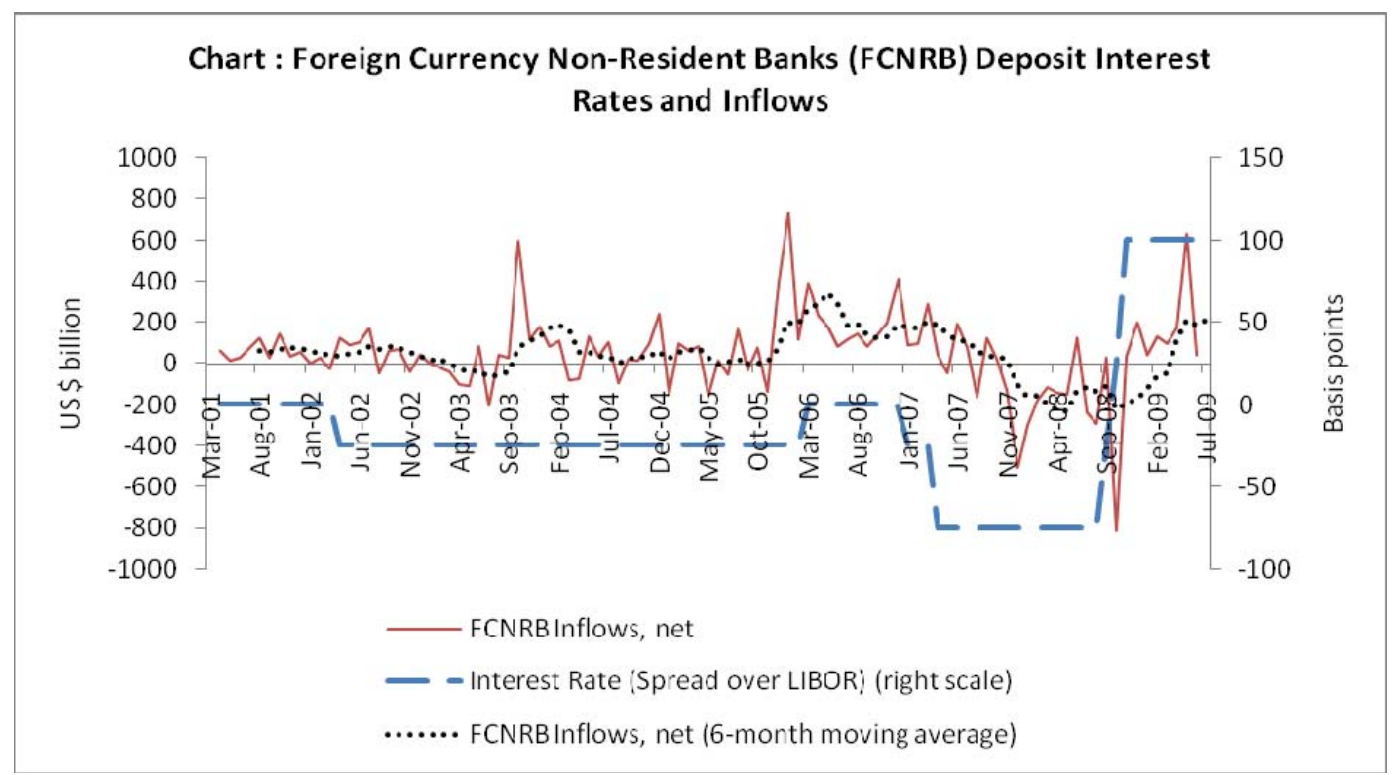




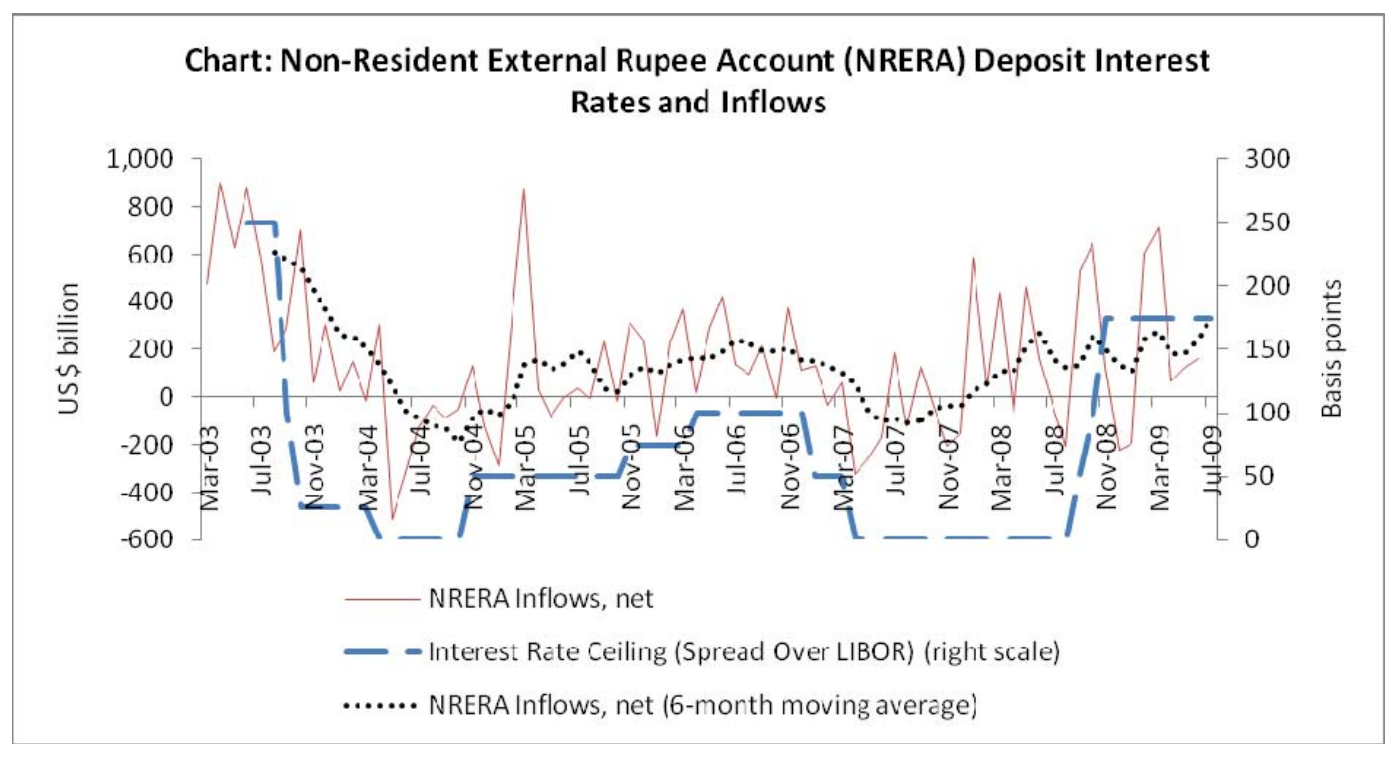

Overall, each component of debt flows is subject to policy modulation in response to changing conditions in both domestic and international capital markets. Experience suggests that the outcomes have largely been responsive to the policy measures used, even though a great deal of judgement has had to be used in making policy changes in a characteristically uncertain environment.

\section{Exchange Rate Management and Foreign Exchange Reserves}

India's exchange rate policy in recent years has been guided by the broad principles of careful monitoring and management of exchange rates with flexibility, without a fixed target or a pre-announced target or a band, coupled with the ability to intervene if and when necessary, while allowing the underlying demand and supply conditions to determine the exchange rate movements over a period in an orderly way. Subject to this predominant objective, the exchange rate policy is guided by the need to reduce excess volatility, prevent the emergence of destabilising speculative activities, help maintain an adequate level of reserves, and develop an orderly foreign exchange market. Indeed, across all financial 
markets, the key objective underlying the operating framework of monetary policy in India is to ensure stable conditions in financial markets by moderating volatility through a flexible use of policy instruments but without a specific view on the level of financial prices. Excessive volatility in the exchange rate has significantly more adverse impact on exports in low-income countries.

In the context of exchange rate management in the presence of large and volatile capital flows, some India specific features need to be recognised. First, unlike other major EMEs, India has generally recorded current account deficits. Second, while the current account deficits have been manageable, merchandise trade deficits are rather high and these have increased rapidly in the past few years. The merchandise trade deficit/GDP ratio generally hovered between 2 and 3 per cent during 19902004 (average of 2.7 per cent over this period). Over the following five years (2004-09), the merchandise trade deficit/GDP ratio more than doubled to an average of 7.2 per cent, reaching 10.4 per cent in 2008-09 (Table 6). While remittances and software exports have somewhat offset the surging trade deficit, high levels of trade deficits cannot be ignored. In contrast, most of Asian EMEs have recorded persistent surpluses on their trade accounts. Some countries such as Hong Kong and Philippines do have trade deficits comparable to India, but their current accounts are still in surplus. Third, net capital inflows have been higher than current account deficits. While FDI inflows have increased substantially in the past 3-4 years, portfolio investments by Flls constitute a large part of capital flows and such flows are relatively volatile. Fourth, while the Indian inflation rate has seen a significant reduction from its levels during the 1970s and 1980s, it is still higher than that in advanced economies and in some EMEs. Overall, there are different forces at play. While the trade deficit, current account deficit and higher inflation differentials would suggest 
downward pressures on the exchange rate, capital flows exert upward pressures.

Table 6: Merchandise Trade and Current Account Balance

\begin{tabular}{|c|c|c|c|c|c|c|}
\hline \multicolumn{7}{|c|}{ (Per cent to GDP) } \\
\hline Country & $\begin{array}{l}\text { 1995-99 } \\
\text { (Average) }\end{array}$ & $\begin{array}{l}2000-04 \\
\text { (Average) }\end{array}$ & 2005 & 2006 & 2007 & 2008 \\
\hline 1 & 2 & 3 & 4 & 5 & 6 & 7 \\
\hline \multicolumn{7}{|c|}{ Merchandise Trade Balance } \\
\hline China & 3.5 & 2.9 & 6.0 & 8.2 & 9.3 & 8.3 \\
\hline Hong Kong & -5.5 & -4.4 & -4.3 & -7.4 & -9.5 & -10.7 \\
\hline Korea & 2.9 & 3.4 & 3.9 & 2.9 & 2.7 & 0.6 \\
\hline Taiwan & 4.8 & 6.7 & 5.5 & 6.6 & 7.9 & 4.6 \\
\hline India & -3.6 & -2.9 & -6.4 & -6.8 & -7.8 & -10.4 \\
\hline Indonesia & 8.9 & 11.9 & 6.1 & 8.1 & 7.6 & 4.6 \\
\hline Malaysia & 12.1 & 21.2 & 24.7 & 23.4 & 20.0 & 23.0 \\
\hline Philippines & -9.4 & -7.5 & -7.9 & -5.7 & -5.8 & -7.5 \\
\hline Singapore & 12.7 & 23.2 & 30.1 & 30.7 & 28.2 & 16.9 \\
\hline Thailand & -0.4 & 2.5 & -4.7 & 0.5 & 4.7 & 0.1 \\
\hline Viet Nam & -5.5 & -2.4 & -4.6 & -4.6 & -14.6 & -14.1 \\
\hline \multicolumn{7}{|c|}{ Current Account Balance } \\
\hline China & 2.0 & 2.4 & 7.2 & 9.4 & 11.0 & 9.8 \\
\hline Hong Kong & 1.1 & 7.5 & 11.4 & 12.1 & 12.3 & 14.2 \\
\hline Korea & 2.0 & 2.1 & 1.8 & 0.6 & 0.6 & -0.7 \\
\hline Taiwan & 2.4 & 6.8 & 4.9 & 7.2 & 8.6 & 6.4 \\
\hline India & -1.2 & 0.6 & -1.2 & -1.1 & -1.5 & -2.6 \\
\hline Indonesia & -0.1 & 3.4 & 0.1 & 3.0 & 2.4 & 0.1 \\
\hline Malaysia & 1.8 & 9.8 & 15.0 & 16.3 & 15.7 & 17.6 \\
\hline Philippines & -3.2 & -0.7 & 2.0 & 4.5 & 4.9 & 2.5 \\
\hline Singapore & 17.4 & 15.6 & 22.7 & 25.4 & 23.5 & 14.8 \\
\hline Thailand & 1.0 & 4.2 & -4.3 & 1.1 & 5.7 & -0.1 \\
\hline Viet Nam & -4.5 & -0.6 & -1.1 & -0.3 & -9.8 & -11.8 \\
\hline
\end{tabular}

Source: Key Indicators for Asia and the Pacific 2009, Asian Development Bank; Reserve Bank of India.

Note: Data for India are on financial year basis. 
The nature of capital flows, exchange rate management and foreign exchange reserves management are closely intertwined. If capital flows are perceived to be permanent, the exchange rate, in principle, should then bear the entire adjustment burden. However, if capital flows are volatile and are perceived to be temporary and reversible, then there is a case for smoothing the exchange rate adjustment. Capital flows reflect both push and pull factors. Whereas pull factors are clearly in the hands of domestic policy authorities and they can be seen as stable, push factors monetary policy stance and other factors in the advanced economies impart uncertainty to the volume of capital inflows. Ex-ante, it is, difficult to know as to whether capital flows are temporary or permanent. For example, the wave of copious capital inflows that started in 2003, along with the emergence of large global imbalances, was viewed by most observers, until the emergence of the sub-prime led crisis, as permanent. Events over the past two years have clearly shown that capital flows are highly volatile and they can change course very quickly. On balance, it would be prudent to presume capital flows as volatile and subject to sudden shocks and absorb them into foreign exchange reserves.

Exchange rate management in India is, therefore, guided by the various considerations noted above, namely, avoidance of excessive volatility, high trade deficits, volatile capital flows, and build-up of adequate foreign exchange reserves. At the same time, movements in the day-today exchange rate largely reflect market forces of demand and supply and there has been a growing degree of two-way movement in the exchange rate (Table 7). During the 1990s, though there were some large discrete changes in the exchange rate, it was otherwise relatively stable for the rest of the time. In contrast, in the past few years, there has been a higher degree of two-way movements in the exchange rate on day-to-day basis. 
Table 7: Exchange Rate of the Indian Rupee vis-à-vis the US dollar

\begin{tabular}{|c|c|c|c|c|c|}
\hline \multirow[t]{2}{*}{ Year } & \multirow{2}{*}{$\begin{array}{r}\text { Coefficient } \\
\text { of variation } \\
\text { (daily data) } \\
\text { (per cent) }\end{array}$} & \multirow{2}{*}{$\begin{array}{r}\text { Daily } \\
\text { absolute } \\
\text { change in the } \\
\text { exchange rate } \\
\text { (annual } \\
\text { average) } \\
\text { (Rupees per } \\
\text { dollar) }\end{array}$} & \multicolumn{3}{|c|}{$\begin{array}{l}\text { Number of days during the year } \\
\text { with daily absolute change of more } \\
\text { than }\end{array}$} \\
\hline & & & $\begin{array}{r}10 \\
\text { paisa }\end{array}$ & $\begin{array}{r}20 \\
\text { paisa }\end{array}$ & 30 paisa \\
\hline 1 & 2 & 3 & 4 & 5 & 6 \\
\hline 1993-94 & 0.10 & 0.01 & 1 & 0 & 0 \\
\hline 1994-95 & 0.29 & 0.01 & 3 & 2 & 1 \\
\hline $1995-96$ & 5.75 & 0.10 & 57 & 34 & 23 \\
\hline $1996-97$ & 1.35 & 0.04 & 21 & 10 & 2 \\
\hline $1997-98$ & 4.21 & 0.07 & 45 & 20 & 10 \\
\hline 1998-99 & 2.12 & 0.05 & 37 & 14 & 6 \\
\hline $1999-2000$ & 0.68 & 0.03 & 8 & 1 & 0 \\
\hline $2000-01$ & 2.35 & 0.04 & 27 & 8 & 1 \\
\hline 2001-02 & 1.47 & 0.04 & 19 & 2 & 1 \\
\hline 2002-03 & 0.94 & 0.03 & 2 & 0 & 0 \\
\hline 2003-04 & 1.56 & 0.05 & 24 & 5 & 3 \\
\hline 2004-05 & 2.30 & 0.10 & 89 & 32 & 13 \\
\hline $2005-06$ & 1.79 & 0.07 & 62 & 13 & 5 \\
\hline $2006-07$ & 1.98 & 0.09 & 88 & 26 & 7 \\
\hline 2007-08 & 2.07 & 0.11 & 102 & 42 & 20 \\
\hline 2008-09 & 7.79 & 0.25 & 159 & 114 & 84 \\
\hline
\end{tabular}

Note: Columns 4, 5 and 6 provide data on the number of days during a year when the daily change in exchange rate (Rupees per US dollar) has exceeded 10 paisa, 20 paisa, and 30 paisa, respectively.

Source: Reserve Bank of India.

In the face of an unprecedented volume of capital flows during 200608, the exchange rate appreciated by 17.8 percent from Rs. 46.54 per US dollar in August 2006 to Rs.39.51 per US dollar in October 2007. The rupee appreciated further to Rs.39.37 in January 2008; it thus appreciated 
by 18.2 per cent with respect to the US $\$$ between August 2006 and January 2008.

As the sub-prime crisis broke out in August 2007 and the Fed started its rate cut cycle, capital flows to India jumped. RBI's net purchases of foreign exchange were as much as US $\$ 49$ billion over the 5-month period September 2007-January 2008 (Chart 4). In the subsequent period, oil prices jumped and capital flows dwindled. Following the collapse of Lehman Brothers, there were large outflows of portfolio capital. Accordingly, the exchange rate depreciated from Rs.39.37 per US dollar (January 2008) to Rs.51.23 (March 2009). Net sales of US \$ 28 billion were witnessed during this period, with the bulk of them occurring in October 2008. Foreign exchange reserves fell to US $\$ 248$ billion in November 2008 (reflecting both foreign exchange sales as well as valuation losses), but have recovered since then to US $\$ 280$ billion (endSeptember 2009). Nominal and real effective exchange rates have also fluctuated in tandem (Chart 5).

As may be seen from this episode, there have been large two-way movements of the exchange rate. However, in view of lumpiness of flows and in order to avoid excessive volatility, the Reserve Bank intervened in the market to smoothen the adjustment process. Flexibility in the exchange rate also helps in avoiding excessive recourse to foreign currency debt by corporates. Adequate foreign exchange reserves buffeted the economy from the most volatile period of capital flows and the steep rise in risk aversion. 


\section{Chart 4}

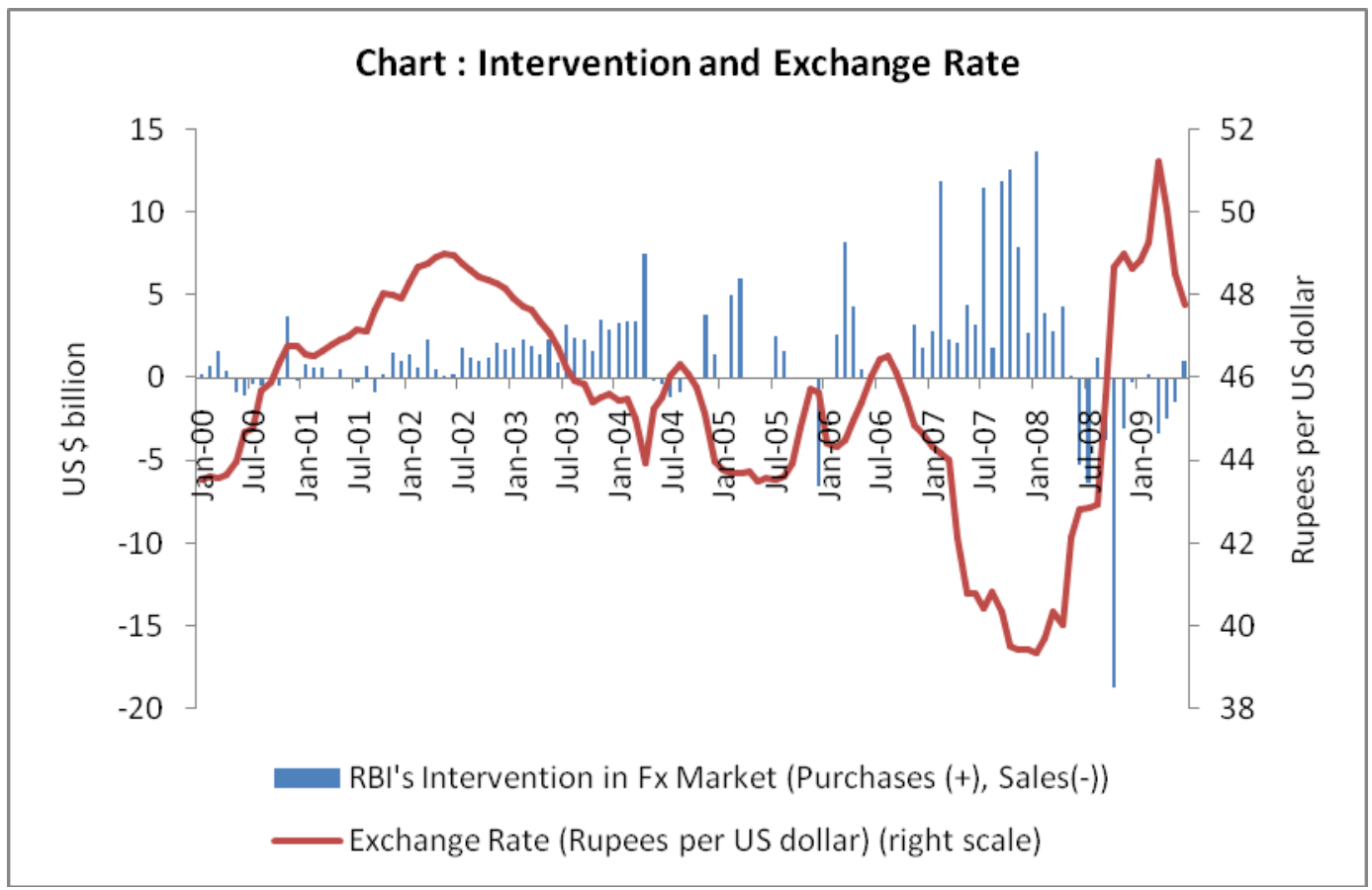

Chart 5

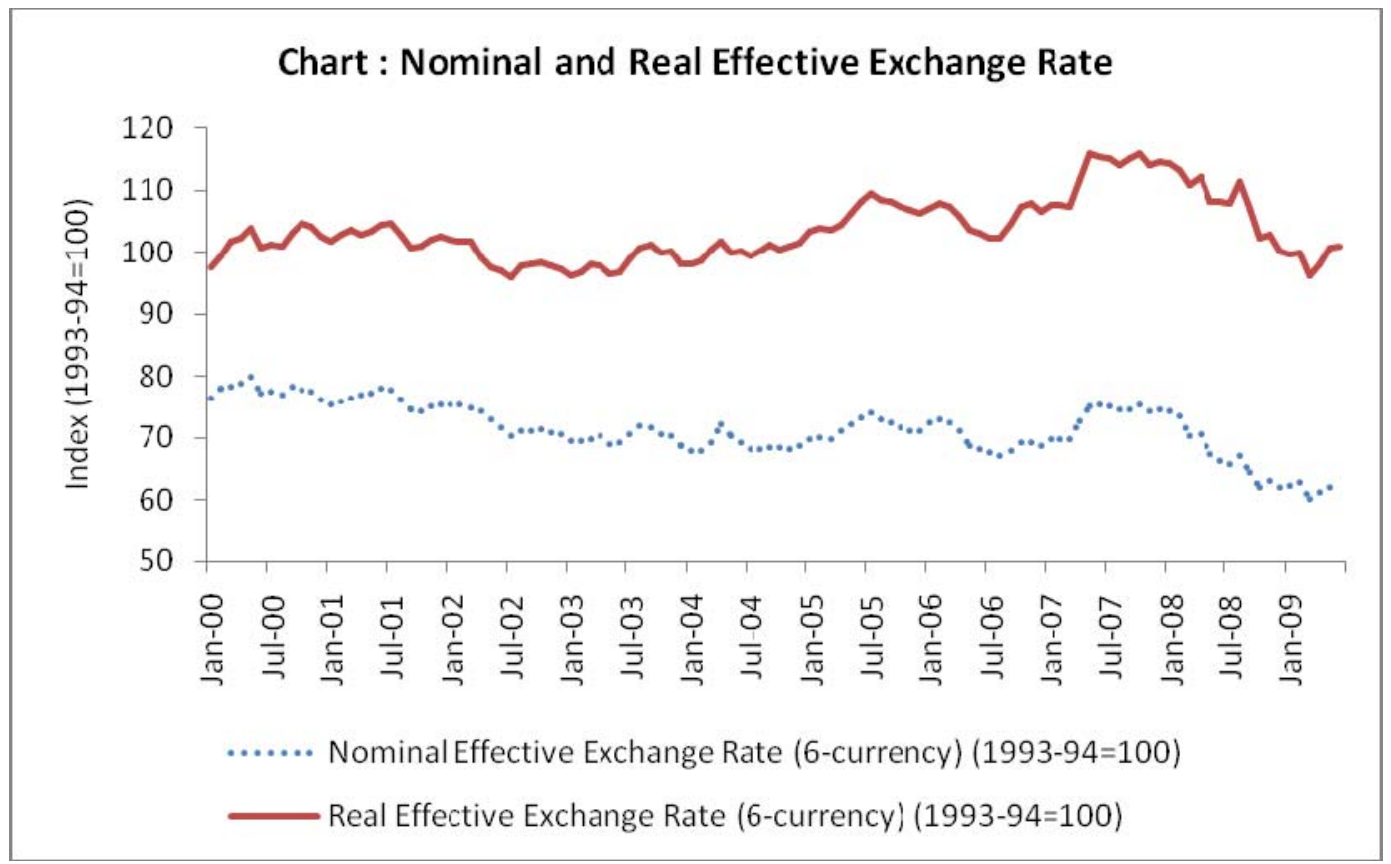




\section{How Open is the Indian Economy?}

Reflecting the liberalisation measures and the active capital account management, both current and capital account transactions have witnessed substantial increases since the early 1990s, especially in the current decade. Current account receipts have more than trebled from 8.2 per cent of GDP in 1990-91 to 29.1 per cent in 2008-09; current account payments also nearly trebled over the same period (Table 8). India is now more open than the United States in the current account: in 2000, India's overall current account openness (the ratio of current receipts and current payments to GDP) at 34.4 per cent was almost similar to that of the US (33.0 per cent). By 2008, India's current account openness at 60.9 per cent was substantially higher than that of the US (41.1 per cent). 


\begin{tabular}{|c|c|c|c|c|c|c|c|c|c|}
\hline \multicolumn{10}{|c|}{ Table 8: India's Balance of Payments - Current Account Transactions } \\
\hline Year & \multicolumn{3}{|c|}{ Trade Account } & \multicolumn{3}{|c|}{ Invisibles Account } & \multicolumn{3}{|c|}{ Current account } \\
\hline & Exports & Imports & Balance & Receipts & Payments & Balance & Receipts & Payments & $\begin{array}{l}\text { Current } \\
\text { Account } \\
\text { Balance }\end{array}$ \\
\hline 1 & 2 & 3 & 4 & 5 & 6 & 7 & 8 & 9 & 10 \\
\hline $1990-91$ & 5.8 & 8.8 & -3.0 & 2.4 & 2.4 & -0.1 & 8.2 & 11.2 & -3.0 \\
\hline 1991-92 & 6.9 & 7.9 & -1.0 & 3.6 & 2.9 & 0.7 & 10.5 & 10.8 & -0.3 \\
\hline $1992-93$ & 7.3 & 9.6 & -2.3 & 3.6 & 3.0 & 0.6 & 10.9 & 12.6 & -1.7 \\
\hline $1993-94$ & 8.2 & 9.7 & -1.5 & 4.1 & 3.1 & 1.0 & 12.3 & 12.8 & -0.4 \\
\hline 1994-95 & 8.3 & 11.1 & -2.8 & 4.8 & 3.1 & 1.8 & 13.1 & 14.2 & -1.0 \\
\hline $1995-96$ & 9.1 & 12.3 & -3.2 & 5.0 & 3.4 & 1.5 & 14.1 & 15.7 & -1.6 \\
\hline $1996-97$ & 8.8 & 12.6 & -3.8 & 5.5 & 2.9 & 2.6 & 14.3 & 15.5 & -1.2 \\
\hline $1997-98$ & 8.7 & 12.5 & -3.8 & 5.6 & 3.2 & 2.4 & 14.3 & 15.7 & -1.4 \\
\hline 1998-99 & 8.2 & 11.4 & -3.2 & 6.2 & 4.0 & 2.2 & 14.4 & 15.4 & -1.0 \\
\hline 1999-00 & 8.3 & 12.3 & -4.0 & 6.7 & 3.8 & 2.9 & 15.0 & 16.1 & -1.0 \\
\hline $2000-01$ & 9.9 & 12.6 & -2.7 & 7.0 & 4.9 & 2.1 & 16.9 & 17.5 & -0.6 \\
\hline 2001-02 & 9.4 & 11.8 & -2.4 & 7.7 & 4.6 & 3.1 & 17.1 & 16.4 & 0.7 \\
\hline 2002-03 & 10.6 & 12.7 & -2.1 & 8.3 & 4.9 & 3.4 & 18.9 & 17.6 & 1.2 \\
\hline 2003-04 & 11.0 & 13.3 & -2.3 & 8.9 & 4.3 & 4.6 & 19.9 & 17.6 & 2.3 \\
\hline 2004-05 & 12.1 & 16.9 & -4.8 & 9.9 & 5.5 & 4.4 & 22.0 & 22.4 & -0.4 \\
\hline $2005-06$ & 13.0 & 19.4 & -6.4 & 11.1 & 5.9 & 5.2 & 24.1 & 25.3 & -1.2 \\
\hline $2006-07$ & 14.1 & 20.9 & -6.8 & 12.5 & 6.8 & 5.7 & 26.6 & 27.7 & -1.1 \\
\hline $2007-08$ & 14.2 & 22.0 & -7.8 & 12.7 & 6.3 & 6.4 & 26.9 & 28.3 & -1.5 \\
\hline $2008-09$ & 15.1 & 25.5 & -10.4 & 14.0 & 6.3 & 7.7 & 29.1 & 31.8 & -2.6 \\
\hline \multicolumn{10}{|l|}{ Memo: } \\
\hline \multicolumn{10}{|c|}{ Amounts in US \$ billion } \\
\hline $1990-91$ & 18 & 28 & -9 & 8 & 8 & 0 & 26 & 36 & -10 \\
\hline $2002-03$ & 54 & 64 & -11 & 42 & 25 & 17 & 96 & 89 & 6 \\
\hline $2007-08$ & 166 & 258 & -92 & 149 & 74 & 75 & 315 & 332 & -17 \\
\hline 2008-09 & 175 & 295 & -119 & 163 & 73 & 90 & 338 & 368 & -30 \\
\hline
\end{tabular}

Source: Reserve Bank of India

Turning to the capital account, after remaining range bound between 1990-91 and 2002-03, gross capital inflows and outflows, as a proportion of GDP, have since grown very rapidly. Gross capital inflows rose from 9.1 per cent of GDP in 2002-03 to 36.8 per cent in 2007-08, before moderating to 25.8 per cent in 2008-09 under the impact of the global financial crisis; gross capital account outflows rose from 7.0 per 
cent to 25.2 per cent over the same period (Table 9). Reflecting these trends, the overall financial openness of the Indian economy - inflows and outflows on current and capital accounts taken together -increased from about 32 per cent in 1990-91 to 120 per cent in 2007-08 before moderating to 112 per cent in the crisis year.

\begin{tabular}{|c|c|c|c|c|c|c|c|}
\hline \multirow[b]{3}{*}{ Year } & \multicolumn{7}{|c|}{$\begin{array}{l}\text { Table 9: India's Balance of Payments - Capital Account } \\
\text { (Per cent to GDP) }\end{array}$} \\
\hline & \multicolumn{5}{|c|}{ Capital Account } & & \multirow{2}{*}{$\begin{array}{r}\text { Overal } \\
\text { Balance o } \\
\text { Payments } \\
\text { Surplus } \\
(+) / \text { Deficit(-) }\end{array}$} \\
\hline & Inflows & Outflows & $\begin{array}{r}\text { Net } \\
\text { Capital } \\
\text { Flows }\end{array}$ & $\begin{array}{r}\text { Foreign } \\
\text { Investment, } \\
\text { net }\end{array}$ & $\begin{array}{r}\text { Debt } \\
\text { Flows, } \\
\text { net }\end{array}$ & $\begin{array}{r}\text { Others, } \\
\text { net }\end{array}$ & \\
\hline 1 & 2 & 3 & 4 & 5 & 6 & 7 & 8 \\
\hline $1990-91$ & 7.2 & 4.9 & 2.3 & 0.0 & 2.2 & 0.0 & -0.8 \\
\hline $1991-92$ & 8.8 & 7.3 & 1.4 & 0.0 & 1.6 & -0.2 & 1.0 \\
\hline $1992-93$ & 8.8 & 7.2 & 1.2 & 0.2 & 1.0 & 0.4 & -0.2 \\
\hline $1993-94$ & 10.5 & 7.3 & 3.5 & 1.5 & 1.1 & 0.6 & 3.1 \\
\hline $1994-95$ & 8.0 & 5.4 & 2.8 & 1.5 & 1.0 & 0.2 & 1.8 \\
\hline $1995-96$ & 6.9 & 5.6 & 1.3 & 1.3 & 0.9 & -1.1 & -0.3 \\
\hline $1996-97$ & 9.3 & 6.2 & 2.9 & 1.5 & 2.1 & -0.5 & 1.7 \\
\hline $1997-98$ & 9.6 & 7.2 & 2.4 & 1.3 & 1.4 & -0.4 & 1.1 \\
\hline $1998-99$ & 8.2 & 6.1 & 2.0 & 0.6 & 1.3 & 0.2 & 1.0 \\
\hline $1999-00$ & 9.0 & 6.7 & 2.5 & 1.1 & 0.7 & 0.5 & 1.4 \\
\hline $2000-01$ & 11.8 & 9.8 & $\begin{array}{r}1.9 \\
(0.7)\end{array}$ & 1.3 & $\begin{array}{r}1.7 \\
(0.5)\end{array}$ & -1.0 & 1.3 \\
\hline 2001-02 & 9.1 & 7.3 & 1.7 & 1.4 & 0.3 & 0.1 & 2.5 \\
\hline 2002-03 & 9.1 & 7.0 & 2.1 & 0.8 & -0.2 & 1.5 & 3.3 \\
\hline $2003-04$ & 12.6 & 9.8 & 2.9 & 2.3 & -0.1 & 0.6 & 5.2 \\
\hline 2004-05 & 14.0 & 10.0 & 4.1 & 1.9 & 1.5 & 0.7 & 3.7 \\
\hline 2005-06 & 17.8 & 14.7 & $\begin{array}{r}3.1 \\
(3.8)\end{array}$ & 1.9 & $\begin{array}{r}1.4 \\
(2.1)\end{array}$ & -0.1 & 1.9 \\
\hline $2006-07$ & 25.5 & 20.5 & 4.9 & 1.6 & 3.2 & 0.1 & 4.0 \\
\hline 2007-08 & 36.8 & 27.6 & 9.2 & 3.8 & 3.6 & 1.8 & 7.9 \\
\hline 2008-09 & 25.8 & 25.2 & 0.8 & 0.3 & 0.7 & -0.2 & -1.7 \\
\hline \multicolumn{8}{|l|}{ Memo: } \\
\hline & & & & & & \multicolumn{2}{|c|}{ Amount in US \$ billion } \\
\hline $1990-91$ & 23 & 16 & 7 & 0 & 7 & 0 & -2 \\
\hline $2002-03$ & 46 & 35 & 11 & 4 & -1 & 8 & 17 \\
\hline 2007-08 & 433 & 325 & 108 & 45 & 42 & 21 & 92 \\
\hline 2008-09 & 302 & 293 & 9 & 3 & 9 & -3 & -20 \\
\hline
\end{tabular}

Note:

1. Debt flows include external assistance, external commercial borrowings, short-term borrowings and non-resident deposits.

2. Figures in parentheses in columns 4 and 6 are after excluding the impact of issuances (2001-02) and redemptions (2005-06) under India Millennium Deposits (IMDs).

Source: Reserve Bank of India. 
Thus, the policy regime in regard to the external sector as well as actual balance of payments data reveal an increasing degree of integration of the Indian economy with the global economy over the past couple of decades. Although the capital account is substantially open, it is managed and can be modulated by policy actions as illustrated earlier.

Despite such a large change in India's external openness, it is surprising that the well-known Chinn-Ito index (Chinn and Ito, 2008) for financial openness ${ }^{6}$ for India is unchanged since 1970, except for a minor blip in 2000 (Annex 3). For other countries such as Thailand, Korea and Philippines, indices are also seen to suffer from inertia for extended periods. Perhaps, this can be attributed to the fact that such studies and the IMF's AREAER view capital account openness as a binary event: either open or closed, when in fact it should be seen as process. Many studies attempting to decipher the impact of financial openness/capital controls on growth and other macroeconomic variables are based on such de jure indices. Conclusions of such studies should be suspect in view of the substantial divergence between the reality and the constructed index.

${ }^{6}$ Chinn-Ito index for financial openness (KAOPEN) is based on the binary dummy variables that codify the tabulation of restrictions on cross-border financial transactions reported in the IMF's Annual Report on Exchange Arrangements and Exchange Restrictions (AREAER). The index takes into account the following four categories of restrictions: (1) presence of multiple exchange rates; (2) restrictions on current account transactions; (3) restrictions on capital account transactions; and (4) requirement of the surrender of export proceeds (Chinn and Ito, 2008). The authors have constructed the indices for 182 countries for the period 1970-2007. In their sample, the minimum and maximum values of the indices are (-) 1.81 and 2.53 , respectively; the median value is (-) 0.59 . 
Trends in Net Capital Inflows

India has generally exhibited current account deficits barring a few episodes of small surplus, generally coinciding with a cyclical slowdown, as in the 3 year period from 2001-02 to 2003-04. However, net capital flows have remained positive and in excess of the current account deficit throughout the whole period since the mid 1990s, leading to accumulation of foreign exchange reserves (Table 9). Net capital flows were relatively modest, less than 3 percent of GDP throughout the decade ending in 2003-04. As elsewhere in the world, however, capital flows jumped after that. During 2004-07, whereas the current account deficit averaged 0.9 percent of GDP, net capital flows rose to 4.0 percent of GDP.

Net capital inflows continued their upward trend during 2007-08, reaching a record high in excess of 9 per cent of GDP (US $\$ 108$ billion) in 2007-08. Reflecting these trends, the overall balance of payments surplus touched 7.9 per cent in 2007-08 as compared with an average of 3.2 per cent during 2004-07 and 3.7 per cent during 2001-04. However, net capital flows plummeted to US $\$ 8$ billion ( 0.8 per cent of GDP) even as the current account deficit widened from 1.5 per cent of GDP in 2007-08 to 2.6 per cent in 2008-09 (Tables 8 and 9). Thus, capital flows have exhibited substantial volatility. It is apparent that India has received excess capital flows which have posed challenges for monetary management. Yet, there have been recommendations for further opening up of capital account. For instance, IMF (2009a) observed that "given the country's massive investment needs, it is essential that scarce fiscal resources be focused on jumpstarting infrastructure investment, together with further opening up to foreign inflows and developing the domestic corporate bond market to augment the needed financing" 


\section{Efficacy of Capital Account Management}

Key components of the capital account show movements in accordance with the policy framework. Thus, inward foreign direct investment (FDI) has increased from negligible levels in early 1990 s to 3.0 per cent of GDP in 2008-09. Outward FDI witnessed a significant jump from 2005-06 onwards to reach 1.5 per cent of GDP in 2008-09 reflecting policy changes encouraging such investments (Table 10). Unlike the secular upward trend in inward and outward FDI, portfolio flows are volatile, which is on expected lines. This volatility is clearly visible in monthly data. Monthly inflows by foreign institutional investors (FIls) in equity markets have ranged between net inflows of US $\$ 7.1$ billion (September 2007, i.e., just after the sub-prime crisis started in the US) and net outflows of US $\$ 9.0$ billion (February 2008) (Chart 6). 
Table 10: Capital Flows: Major Components

\begin{tabular}{|c|c|c|c|c|c|c|c|c|}
\hline \multirow[b]{2}{*}{ Year } & \multicolumn{3}{|c|}{ Non-Debt Flows } & \multicolumn{5}{|c|}{ Debt Flows } \\
\hline & $\begin{array}{r}\text { Inward } \\
\text { FDI, } \\
\text { net }\end{array}$ & $\begin{array}{r}\text { Outward } \\
\text { FDI, } \\
\text { net }\end{array}$ & $\begin{array}{r}\text { Inward } \\
\text { Portfolio, } \\
\text { net }\end{array}$ & $\begin{array}{r}\text { External } \\
\text { Assistance, } \\
\text { net }\end{array}$ & $\begin{array}{r}\mathrm{ECB}, \\
\text { net }\end{array}$ & $\begin{array}{r}\text { ECB } \\
\text { Disbursements }\end{array}$ & $\begin{array}{r}\text { Short-term } \\
\text { Borrowings, } \\
\text { net }\end{array}$ & $\begin{array}{r}\text { Non- } \\
\text { Resident } \\
\text { Deposits, } \\
\text { net }\end{array}$ \\
\hline 1 & 2 & 3 & 4 & 5 & 6 & 7 & 8 & 9 \\
\hline $1990-91$ & 0.0 & 0.0 & 0.0 & 0.7 & 0.7 & 1.3 & 0.3 & 0.5 \\
\hline $1991-92$ & 0.0 & 0.0 & 0.0 & 1.1 & 0.5 & 1.2 & -0.2 & 0.1 \\
\hline $1992-93$ & 0.1 & 0.0 & 0.1 & 0.8 & -0.1 & 0.5 & -0.4 & 0.8 \\
\hline $1993-94$ & 0.2 & 0.0 & 1.3 & 0.7 & 0.2 & 1.1 & -0.3 & 0.4 \\
\hline $1994-95$ & 0.4 & 0.0 & 1.1 & 0.5 & 0.3 & 1.3 & 0.1 & 0.1 \\
\hline $1995-96$ & 0.6 & 0.1 & 0.7 & 0.2 & 0.4 & 1.2 & 0.0 & 0.3 \\
\hline $1996-97$ & 0.7 & 0.0 & 0.9 & 0.3 & 0.7 & 1.9 & 0.2 & 0.9 \\
\hline $1997-98$ & 0.9 & 0.0 & 0.4 & 0.2 & 1.0 & 1.8 & 0.0 & 0.3 \\
\hline 1998-99 & 0.6 & 0.0 & 0.0 & 0.2 & 1.0 & 1.7 & -0.2 & 0.2 \\
\hline $1999-00$ & 0.5 & 0.0 & 0.7 & 0.2 & 0.1 & 0.7 & 0.1 & 0.3 \\
\hline $2000-01$ & 0.9 & 0.2 & 0.6 & 0.1 & $\begin{array}{r}0.9 \\
(-0.1)\end{array}$ & $\begin{array}{r}2.1 \\
(0.9)\end{array}$ & 0.1 & 0.5 \\
\hline 2001-02 & 1.3 & 0.3 & 0.4 & 0.3 & -0.3 & 0.6 & -0.2 & 0.6 \\
\hline 2002-03 & 1.0 & 0.4 & 0.2 & -0.6 & -0.3 & 0.7 & 0.2 & 0.6 \\
\hline 2003-04 & 0.7 & 0.3 & 1.9 & -0.5 & -0.5 & 0.9 & 0.2 & 0.6 \\
\hline 2004-05 & 0.9 & 0.3 & 1.3 & 0.3 & 0.8 & 1.3 & 0.5 & -0.1 \\
\hline 2005-06 & 1.1 & 0.7 & 1.5 & 0.2 & $\begin{array}{r}0.3 \\
(1.0)\end{array}$ & $\begin{array}{r}1.8 \\
(2.5)\end{array}$ & 0.5 & 0.3 \\
\hline 2006-07 & 2.5 & 1.6 & 0.8 & 0.2 & 1.8 & 2.2 & 0.7 & 0.5 \\
\hline 2007-08 & 2.9 & 1.6 & 2.5 & 0.2 & 1.9 & 2.5 & 1.5 & 0.0 \\
\hline 2008-09 & 3.0 & 1.5 & -1.2 & 0.2 & 0.6 & 1.2 & -0.5 & 0.4 \\
\hline
\end{tabular}

Note:

FDI: Foreign Direct Investment; ECB: External Commercial Borrowings.

Figures in parentheses in columns 5 and 6 are after excluding the impact of issuances (2001-02) and redemptions (2005-06) under India Millennium Deposits (IMDs).

Source: Reserve Bank of India 


\section{Chart 6}

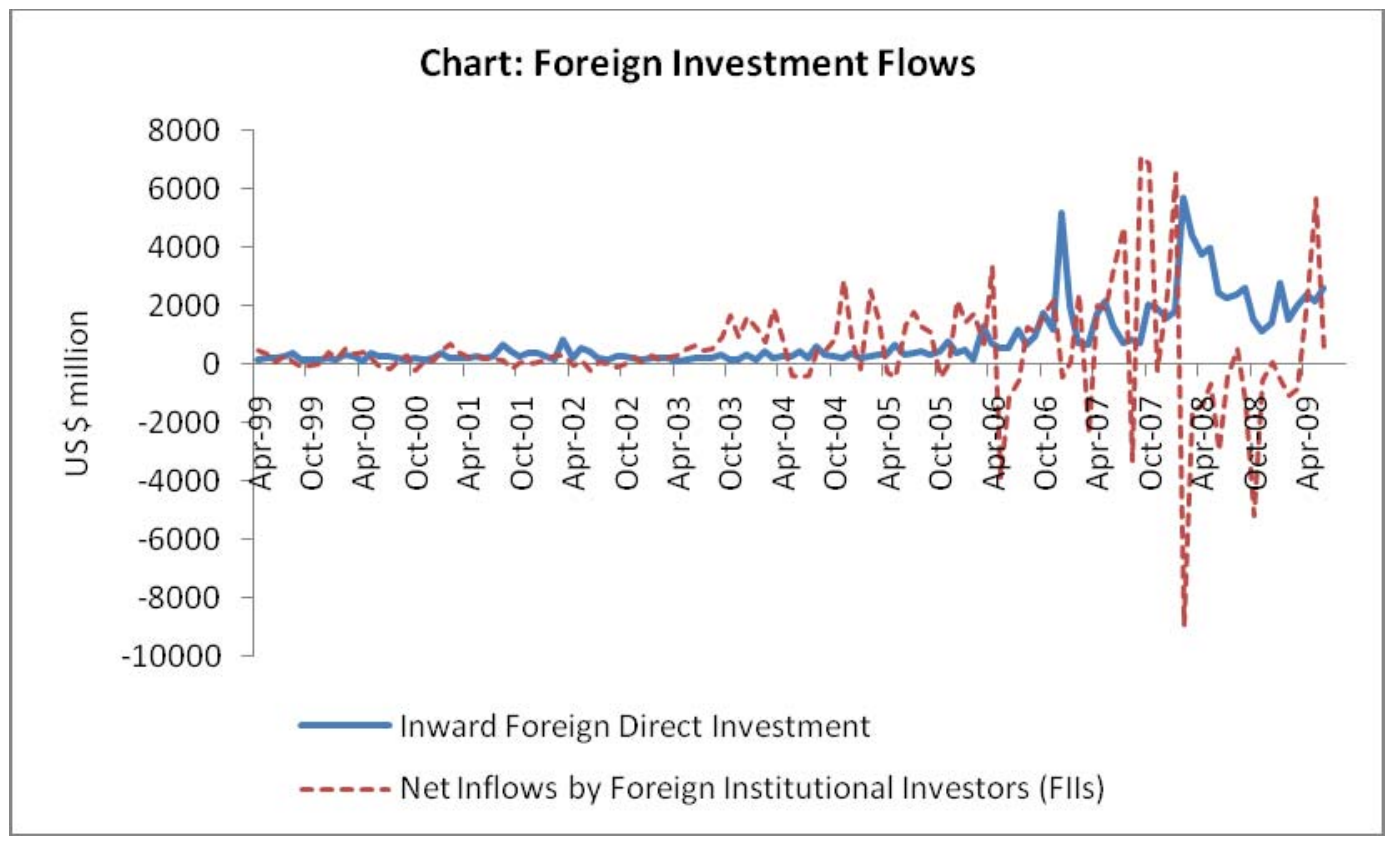

Amongst debt flows, official aid is now almost negligible, and it is the external commercial borrowing (ECB) by non financial companies that dominates. Annual disbursements under ECBs generally move in line with investment demand in the economy and have hovered around 2 per cent of GDP, which is consistent with the policy of annual ceilings for such borrowings. Short-term borrowings have remained modest ${ }^{7}$. Inflows under non-resident deposits have remained under one per cent of GDP (Table 10). In brief, capital flows (net) have increased rapidly since 2003-04. They have been evenly balanced between debt and non-debt flows; they have also exhibited more volatility since early 2004 (Chart 7).

\footnotetext{
${ }^{7}$ The increase in short-term borrowings during 2004-08, particularly in 2007-08, reflected the impact of higher international crude prices on the short term financing needs of domestic oil companies.
} 
Chart 7

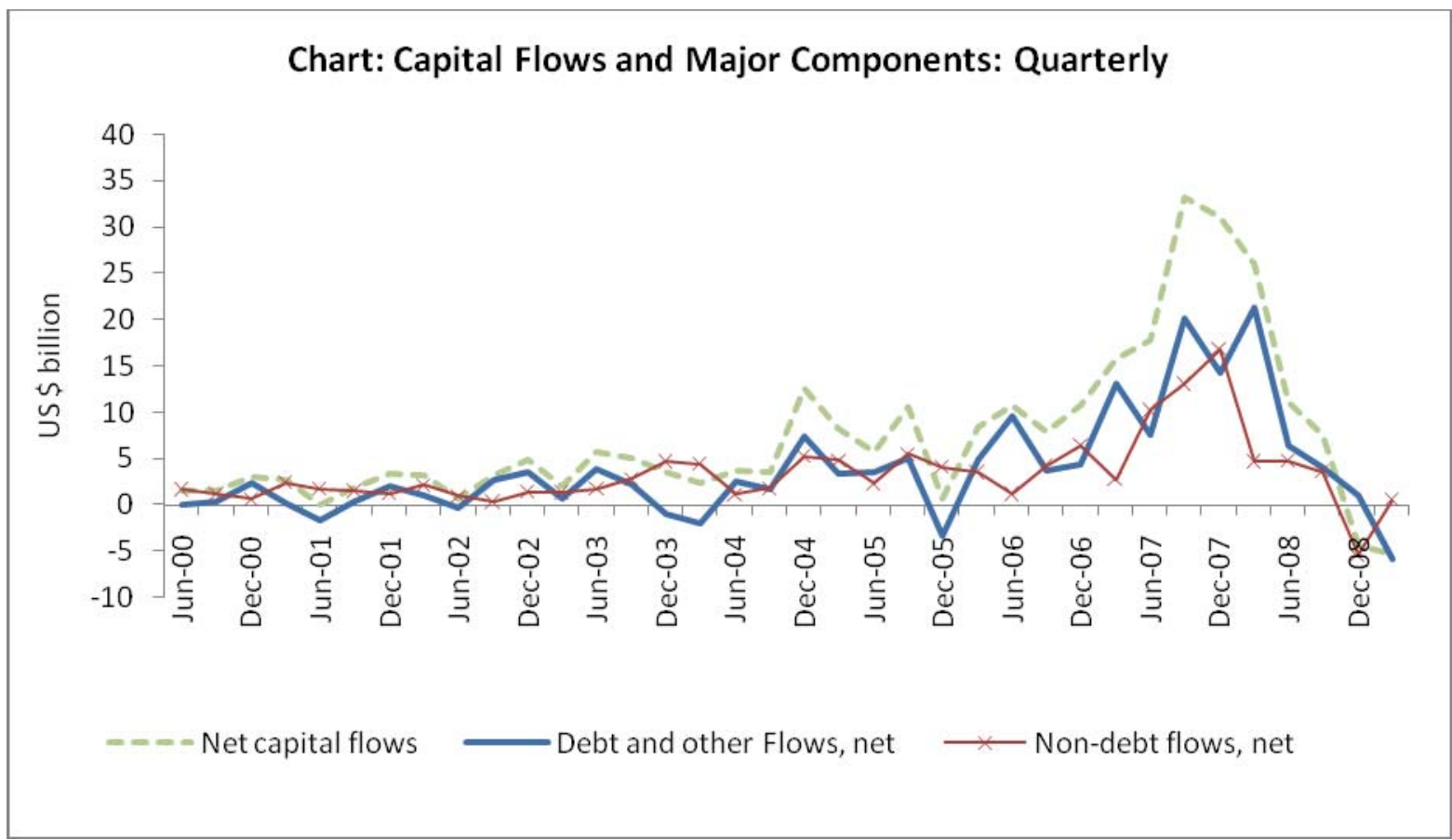

\section{Net Capital Flows to India: Cross-Country Perspective}

Net capital flows during 2007-08 were the highest in India's history. Cross-country analysis indicates a number of interesting features. First, India was the largest recipient of net capital flows amongst all EMEs during 2007. With net capital flows of US \$ 98 billion during 2007 (calendar year basis), India was ahead of Russia (US \$ 96 billion), Brazil (US\$ 88 billion) and China (US $\$ 70$ billion). India, thus, received one-sixth of net capital flows received by all EMEs during 2007 (Annex 4). Second, India was the third largest recipient of net capital flows during 2007 amongst all countries - after US and Spain. Third, during 2008 - the year of crisis - India was the second highest recipient of net capital flows amongst EMEs (after Poland). Russia recorded large capital outflows (US $\$ 136$ billion) in 2008 - a substantial turnaround from 2007. In fact, Russia 
topped the list of EMEs that recorded outflows during 2008 followed by Korea. Fourth, at the global level, a clear flight to safety is seen in 2008 towards euro area, whose capital flows jumped 10 times to US \$446 billion in 2008.

The Indian experience with regard to capital flows reveals interesting differences with other major Asian EMEs. Net capital inflows to other Asian EMEs (with exception of China) have been relatively modest compared to India (even in terms of per cent to GDP) (Mohan and Kapur, 2009). In all cases, except India, net capital flows during 2003-07 (per cent to GDP) were lower than their 1990-96 levels. These dynamics can perhaps be explained by slump in investment and growth rates in most of the Asian EMEs, except India and China, since the Asian crisis.

The overall experience of EMEs, and that of India, is clearly one of broadly increasing volumes of and greater volatility in cross border capital flows, even as they have practised greater flexibility in their exchange rate regimes. Few EMEs practise the corner solutions of fixed exchange rates or completely open capital accounts. They have also practised flexibility in monetary policy frameworks and in financial regulation in the interest of preserving overall financial stability. Accordingly, we now turn to the details of Indian monetary and financial management as practised in recent years. 


\section{MONETARY MANAGEMENT IN THE FACE OF CAPITAL FLOW VOLATILITY}

\section{Monetary Policy: Framework, Objectives and Instruments}

The conduct of monetary policy by the Reserve Bank is guided by the objective of maintenance of price stability and financial stability, while providing support to growth though adequate availability of credit. Furthermore, the Reserve Bank is also responsible for development and regulation of the banking sector and key segments of financial markets, foreign exchange management and public debt management. Globally, financial stability is emerging as an explicit objective for central banks only after the global financial crisis. In India, financial stability has been an explicit objective of the Reserve Bank since the early part of this decade. This reflected a combination of factors, namely, the growing degree of financial deregulation and liberalisation, low income levels and limited capacity of the majority of population to bear downside risks. Thus, unlike the trend towards single objective (price stability/inflation targeting), monetary policy framework in India is based on multiple objectives and multiple instruments.

While price stability remains a key objective, an inflation targeting framework has not been considered appropriate for a variety of reasons: recurrent supply shocks from vagaries of the monsoon; large weight of food prices (46-70 per cent) in various consumer price indices; heterogeneity in consumption habits across different regions which render difficulty in acceptance of a single consumer price index for the country as a whole; large fiscal deficits and market borrowings; and, impediments to monetary transmission due to administered interest rates in some segments (Mohan, 2007; Subbarao, 2009). Apart from the Indian specifics, such a framework was - well before the current crisis hit us - 
considered to be too narrow and unsuitable given the complexities that a central bank faces in its objectives (Mohan, 2004). The global financial crisis has now justified such concerns.

In view of deregulation and liberalisation of the Indian economy that began in the early 1990s, and gradual development of financial markets, the monetary policy framework switched from the extant monetary targeting framework to a 'multiple indicators' approach in 1998. Under this framework, which continues to be in place, monetary policy signals are largely transmitted through modulations in policy rates (repo/reverse repo rates under the daily LAF). Unlike other major banks, no single/central rate is targeted. Rather, the Reserve Bank has preferred a band approach in view of large and recurrent exogenous shocks to liquidity emanating from volatility in capital flows and government cash flows. In case the Reserve Bank is in a tightening mode, the LAF repo rate becomes the effective signalling rate; in the case of accommodative stance, the LAF reverse repo rate takes the place of the signalling rate.

Along with changes in policy rates, the width of the repo-reverse repo rate corridor has also been used as an instrument of signalling. The width has varied between 100 and 300 basis points and is 150 basis points at present (September 2009). The width reflects evolving macroeconomic and monetary conditions, trends in capital flows as well as the level of uncertainty. We have been amongst a few banks where corridor width has been employed as an instrument of monetary policy. In the context of corridor width, it is interesting to note the following observations of Charles Goodhart (2009):

"While decisions on the level of the official rate, within this corridor, are much more important than adjustments to the parameters of the corridor itself, nevertheless the latter could become a flexible and subtle further instrument". 
"In several cases around the world, these margins have been set, often by historical tradition, at plus, or minus, some round number, often $1 \%$, and then left there as a constant, irrespective of economic conjuncture, or the positions of either the banking sector as a whole, or of individual banks within it, with the Central Bank".

"Treating these parameters as a constant would be a waste of a good instrument. ...(T)his spread should have narrowed as we moved from pre-crisis peace-time to war-time crisis conditions".

"The parameters of the 'corridor' could, and should be managed in a more flexible, subtle and intelligent way than has been generally done to date".

In addition, in view of the large potential changes in monetary aggregates, largely caused by the volatility in capital flows, the Reserve Bank also uses changes in instruments such as the "Cash Reserve Ratio" (CRR) and the "Statutory Liquidity Ratio" $(\mathrm{SLR})^{8}$ to modulate liquidity in the system, and to keep the trends in monetary aggregates within the desired trajectories. Sterilisation operations have been an important component of monetary management in the face of volatile capital flows. Furthermore, as will be detailed later, prudential regulations have been used in an integrated manner as supplements to overall monetary policy. Such measures have generally been used to respond to the observation of large movements in credit growth to certain sectors, particularly when such movement could lead to excessive growth in asset prices with potential effects on financial stability.

\section{Sterilisation Operations}

While efforts have been made to liberalise capital outflows and restrict debt flows, capital inflows (net) have been, for most of the time, above

\footnotetext{
${ }^{8}$ The SLR regulation mandates the banks to invest a specified proportion (at present 24 percent) of their net demand and time liabilities (NDTL) in government (and other specified) securities.
} 
financing requirements. Excess foreign exchange flows are absorbed by the Reserve Bank and equivalent rupee liquidity is provided to banks. Absorption of excess capital flows by a central bank has implications for domestic monetary and liquidity conditions and, beyond a limit, such absorptions can be inflationary and lead to a vicious circle of bust and boom. Rather than relying on a single instrument, a combination of instruments has been used in India to neutralise the expansionary impact of foreign exchange purchases on domestic monetary and liquidity conditions. These include: open market operations, market stabilisation scheme, cash reserve ratio, liquidity adjustment facility, and, at times, modulation in Centre's surplus cash balances.

Fiscal dominance of the 1970s and 1980s had left a large pool of Government securities with the Reserve Bank and such assets dominated the Reserve Bank's balance sheet in the early 1990s. Foreign exchange assets constituted only a miniscule proportion. Thus, as capital flows increased from 1993-94 onwards, such accumulated holdings of government securities came in handy for sterilisation purposes and open market operations (OMO) in government securities were the main instrument of sterilisation for almost a decade. By 2003-04, however, the stock of such securities had dwindled on the back of continuous sterilisation operations. The Reserve Bank of India Act prohibits issuance of its own securities by the Reserve Bank. Furthermore, the Reserve Bank's LAF operations are collateralised against government securities. Absorption of liquidity under reverse repos is against government securities held in RBl's portfolio and vice versa for repos. Therefore, a certain stock of government securities is required to be held by $\mathrm{RBI}$ for normal monetary management.

In view of the finite stock of government securities in the RBI's balance sheet, the provisions of the $\mathrm{RBI}$ Act prohibiting issuance of its own 
securities, and need for government securities for operating the LAF, an innovation in the form of Market Stabilisation Scheme (MSS) was introduced in 2004. Under the MSS, the Reserve Bank of India is authorized by the Government to issue Government Treasury bills/bonds to offset the expansionary impact of capital inflows, up to a specified limit. MSS securities are identical to normal government securities in the hands of the investors and there is no distinction between the two. However, MSS proceeds are impounded in a separate account with the Reserve Bank and these can only be used for redemption ${ }^{9}$. Interest payments on MSS securities are borne by the Government and these payments are shown in the budget documents - these have averaged only 0.13 per cent of GDP over the period 2004-09. MSS operates symmetrically: during episodes of capital outflows, liquidity is injected into the banking system through normal redemptions as well as active buybacks. This imparts flexibility to the conduct of monetary policy. Thus, liquidity was injected quickly through such unwinding during 2008-09 and 2009-10 as capital flows reversed following the failure of Lehman Brothers. Although the interest burden on MSS operations is borne by the government, the fiscal cost incurred is compensated by the transfer of higher surplus transferable profits from the Reserve Bank. This higher transfer is enabled by the higher accretion of $\mathrm{RBI}$ earnings on account of enhanced foreign exchange reserves, with the increment in reserves being significantly higher than the issuance of MSS securities (Table 11).

\footnotetext{
${ }^{9}$ In view of large jump in fiscal deficit and market borrowing requirements on the back of stimulus measures in the aftermath of global financial crisis, a part (Rs.400 billion) of MSS proceeds impounded with the Reserve Bank was permitted to be desequestered in two stages (March 2009 and May 2009), consistent with the announced government borrowing programme.
} 
Table 11: Market Stabilisation Scheme in India

(Rupees billion)

\begin{tabular}{|c|c|c|c|c|c|}
\hline Item & $\begin{array}{r}2004- \\
05\end{array}$ & 2005-06 & 2006-07 & 2007-08 & 2008-09 \\
\hline 1 & 2 & 3 & 4 & 5 & 6 \\
\hline $\begin{array}{l}\text { 1. Balances under Market Stabilisation Scheme } \\
\text { (MSS) (outstanding, end-March) }\end{array}$ & 642 & 291 & 630 & 1,684 & 881 \\
\hline \multirow{2}{*}{$\begin{array}{l}\text { 2. Interest paid by the Government on issuances } \\
\text { under the MSS during the year (April-March) }\end{array}$} & 21 & 34 & 26 & 84 & 124 \\
\hline & $(0.07)$ & $(0.09)$ & $(0.06)$ & $(0.18)$ & $(0.23)$ \\
\hline $\begin{array}{l}\text { 3. Foreign Currency Assets of the Reserve Bank } \\
\text { (outstanding, end-March) }\end{array}$ & 5,931 & 6,473 & 8,366 & 11,960 & 12,301 \\
\hline $\begin{array}{l}\text { 4. Net Disposable Income of the Reserve Bank } \\
\text { during the year (July-June) }\end{array}$ & 54 & 84 & 114 & 150 & 250 \\
\hline $\begin{array}{l}\text { 5. Surplus Transfer from the Reserve Bank to the } \\
\text { Central Government during the year (July-June) }\end{array}$ & 54 & 84 & $114 @$ & 150 & 250 \\
\hline \multicolumn{6}{|l|}{ Memo: } \\
\hline $\begin{array}{l}\text { Net issuance }(+) / \text { redemption of MSS during the } \\
\text { year }\end{array}$ & 642 & -351 & 279 & 1054 & -803 \\
\hline
\end{tabular}

@: Excluding profits on sale of shares of State Bank of India.

Figures in parentheses are per cent to GDP

Source: Reserve Bank of India; Budget Documents, Government of India.

\section{Liquidity Management}

Like China and other countries, the cash reserve ratio (CRR) has been deployed to moderate the impact of volatility in capital flows on domestic monetary and credit aggregates and prevent overheating between 2004 to around mid-2008 (Mohan, 2008a). Thus, CRR was raised from 4.5 per cent in March 2004 to 9.0 per cent by July 2008. As capital flows reversed, the increases were rolled back between September 2008 and January 2008 (Chart 8). While the increase in the CRR was gradual, the reversal was quick to compensate for the liquidity drain caused by forex interventions resulting from rapid capital outflows after the Lehman 
bankruptcy. The domestic banking system was thus largely insulated from both the large influx and the subsequent reversal of capital flows.

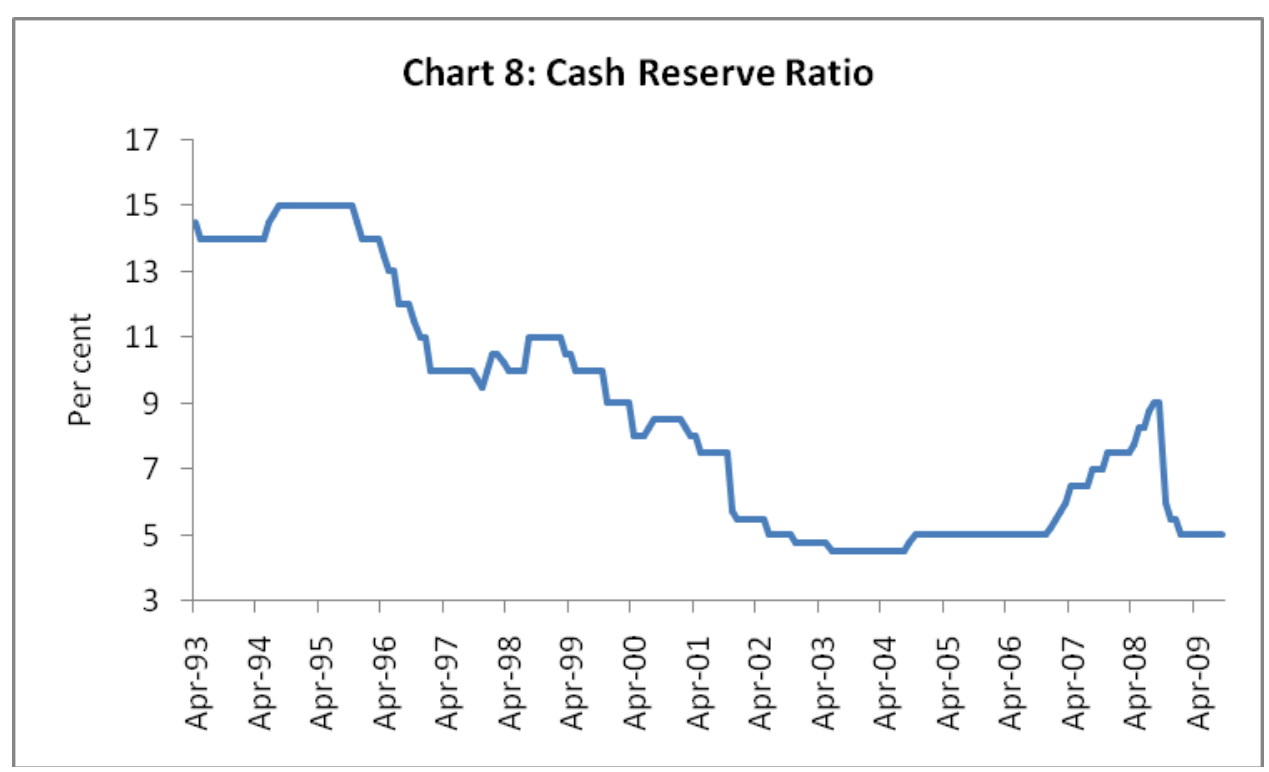

Reserve requirements, along with MSS, provided a liquidity cushion that could be released when the banks faced greater funding difficulties. Banks could be given back their own liquidity and there was no need for any dilution of collateral accepted by the Reserve Bank for injection of liquidity into the system. Actual/potential liquidity through these measures amounted to Rs. 5,617 billion (10.6 per cent of GDP for the year 2008-09) (Table 12). In view of these factors, ample liquidity was provided to the banking system and this is reflected in continuous absorption under reverse repos since December 2008. During January-July 2009, daily liquidity absorbed under LAF reverse repos averaged around Rs.900 billion (reaching Rs.1,300 billion in July 2009) (Chart 9). However, even as there has been ample liquidity in the banking system, there has been no visible expansion of RBl's balance sheet and reserve money. This is in contrast to the sharp expansion of balance sheets in major advanced 
economies. Ample liquidity, without any observed expansion in RBl's balance sheet, can be attributed to fact that CRR balances are a part of reserve money. Reduction in CRR shows up as reduction in reserve money, as explained in detail later. In view of CRR impact, reserve money should be adjusted for the policy-induced change. A cursory look at balance sheet and reserve money dynamics can be misleading. 
Table 12: Actual/Potential Release of Primary Liquidity

(since mid-September 2008)

Measure/Facility

Amount

(Rs. billion)

Monetary Policy Operations (1 to 3)

1. Cash Reserve Ratio (CRR) Reduction $\quad 1,600$

2.Open Market Operations $\quad 801$

3. MSS Unwinding/De-sequestering $\quad 1,555$

Extension of Liquidity Facilities (4 to 8)

4. Term Repo Facility @ 600

5. Increase in Export Credit Refinance \# 266

6. Special Refinance Facility for SCBs (Non-RRB) \$ 385

7. Refinance Facility for SIDBI/NHB/EXIM Bank 160

8. Liquidity Facility for NBFCs through SPV @@ 250

Total (1 to 8) $\quad 5,617$

Memo:

Statutory Liquidity Ratio (SLR) Reduction

400

\section{Notes:}

@: 14-days term repo facility instituted under the LAF to enable banks to ease liquidity stress faced by mutual funds (MFs), non-banking financial companies (NBFCs) and housing finance companies.

\#: The export credit refinance (ECR) limit was increased from 15 per cent of the outstanding rupee export credit eligible for refinance to 50 per cent.

\$: Introduced under Section 17(3B) of the Reserve Bank of India Act, 1934 to provide all scheduled commercial banks (excluding RRBs) refinance from the Reserve Bank equivalent to up to 1.0 per cent of their respective net demand and time liabilities (NDTL) up to a maximum period of 90 days.

@@: To address the temporary liquidity constraints of systemically important nondeposit taking NBFCs (NBFCs-ND-SI), the Government set up a special purpose vehicle (SPV). The SPV was allowed to mobilise resources through issuance of government guaranteed securities (for investment in CPs and NCDs of NBFCs-NDSI) to be purchased by the Reserve Bank. 
Chart 9

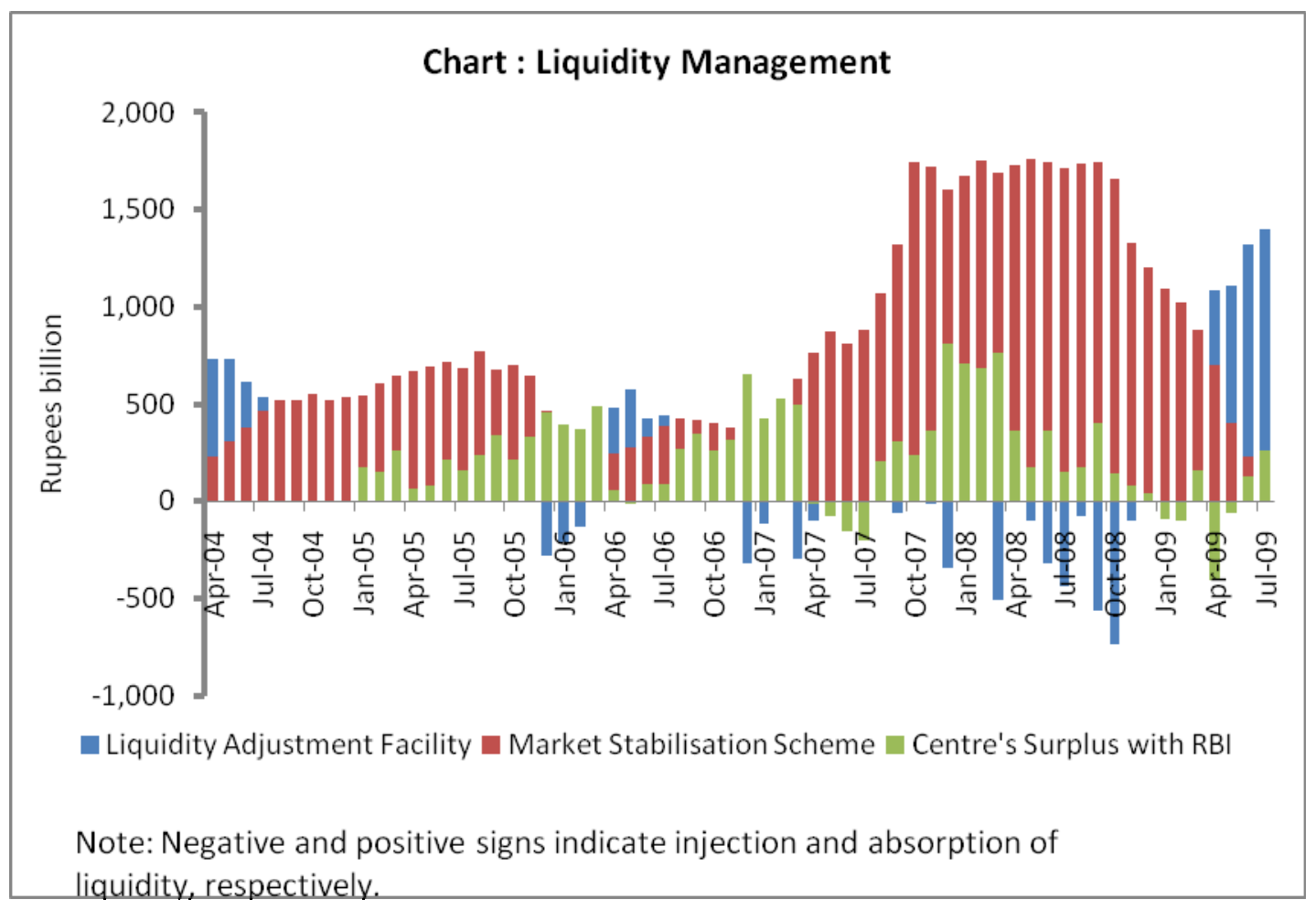

While CRR and MSS have been used to sterilise relatively durable capital flows, repo/reverse operations under the daily liquidity adjustment facility (LAF) help to manage transient liquidity shortfalls/surpluses in the money market. Within the MSS operations there is built in flexibility to deal with the durability of inflows, or otherwise, on an ex post basis. MSS securities are issued with maturities ranging from 91 day treasury bills to longer term government securities with maturities of up to about 3 years. So the sterilised liquidity can be unwound on a flexible basis depending on the pattern of capital flows. LAF operations, as elaborated later, have been an important tool of monetary management in the face of capital flows. In the case of MSS, as noted earlier, the burden is borne by the government. In the case of LAF operations, the burden of excess liquidity absorbed under reverse repos is borne by the Reserve Bank. Finally, in 
the case of CRR, the burden is now borne by banks. Amendment to the RBI Act in 2007 prohibits the Reserve Bank from paying interest on CRR balances. Prior to this, the required CRR balances earned interest. At present, the burden of sterilisation is thus shared between the government, the Reserve Bank and banks.

Apart from policy actions of CRR, OMOs, and MSS, in the context of sterilisation, it needs to be recognised that a fast growing economy like India needs a corresponding expansion in monetary aggregates, which then have to be underpinned by an appropriate expansion of the central bank's balance sheet, which can be through expansion of domestic assets or foreign assets. If it is through expansion of foreign assets, it is apparent that if the foreign assets acquired by the central bank through its market interventions are consistent with the desired base money growth they need not be sterilised. Thus, only part of the increase in the central bank's balance sheet through accretion of foreign assets needs to be sterilized If the accretion is in excess of the required base money growth. For instance, during 2007-08, RBl's market purchases of foreign exchange amounted to US $\$ 78$ billion, while currency demand amounted to Rs. 856 billion (around US $\$ 21$ billion). Thus, only US \$ 57 billion (around threefourths of intervention during the year) was required to be sterilised. More generally, it is clear that sterilisation coefficient would be less than unity. Sterilisation operations through CRR, OMOs and MSS take into account absorption through currency demand as well as through existing levels of CRR (Table 13). Finally, LAF balances liquidity surpluses/shortfalls on a daily basis. Therefore, looking at only MSS and OMOs as instruments of sterilisation and arguing that sterilisation was partial, is analytically incorrect (e.g. Shah and Patnaik (2008)). 
Table 13: Sterilisation Operations by the Reserve Bank of India

\begin{tabular}{|c|c|c|c|c|c|c|c|}
\hline & & & & & & \multicolumn{2}{|c|}{ Rupees billion } \\
\hline & Item & $\begin{array}{r}2003- \\
04 \\
\end{array}$ & $\begin{array}{r}2004- \\
05 \\
\end{array}$ & $\begin{array}{r}2005- \\
06 \\
\end{array}$ & $\begin{array}{r}2006- \\
07 \\
\end{array}$ & $\begin{array}{r}2007- \\
08\end{array}$ & $\begin{array}{r}2008- \\
09 \\
\end{array}$ \\
\hline & 1 & 2 & 3 & 4 & 5 & 6 & 7 \\
\hline 1 & $\begin{array}{l}\text { Market Purchases(+)/Sales(-) of Foreign } \\
\text { Currency by RBI }\end{array}$ & 1407 & 911 & 329 & 1190 & 3121 & -1786 \\
\hline 2 & Management of Liquidity $(\mathrm{I}+\mathrm{ii}+\mathrm{iii})$ & -1398 & -1076 & -429 & -1219 & -2804 & 1574 \\
\hline & (i) Policy Actions (a to c) & -356 & -732 & 459 & -607 & -1389 & 2870 \\
\hline & (a) Change in CRR (first round) & 35 & -90 & 0 & -275 & -470 & 1023 \\
\hline & (b) MSS Operations & 0 & -642 & 351 & -339 & -1054 & 803 \\
\hline & (c) OMOs & -391 & 0 & 107 & 7 & 135 & 1045 \\
\hline & (ii) Other Factors (a to c) & -720 & -497 & -1009 & -976 & -1626 & -778 \\
\hline & (a) Currency with public & -434 & -409 & -573 & -698 & -856 & -979 \\
\hline & (b) Existing CRR & -108 & -93 & -209 & -267 & -504 & -402 \\
\hline & $\begin{array}{l}\text { (c) Surplus cash balance of the Central } \\
\text { Government with RBI }\end{array}$ & -178 & 5 & -227 & -12 & -266 & 604 \\
\hline & (iii) LAF Operations & -322 & 153 & 121 & 364 & 212 & -518 \\
\hline
\end{tabular}

\section{Note:}

CRR: Cash Reserve Ratio; MSS: Market Stabilization Scheme; LAF: Liquidity Adjustment Facility; OMOs: Open Market Operations

(-) indicates absorption of liquidity from the banking system and (+) indicates injection of liquidity.

Source: Reserve Bank of India

A usual concern with sterilisation is that it involves quasi-fiscal costs as the central bank sheds high-yielding domestic securities for lowyielding foreign assets. While factually true, such arguments ignore the fact that the quasi-fiscal and other costs of sterilization can be compensated by the returns obtained from the higher amount of forex reserve accumulation and, furthermore, are also likely to be outweighed by the benefits that may emanate from the maintenance of domestic macroeconomic and financial stability. Large reserves apparently lower spreads on overseas borrowing costs of domestic corporates. In the 
current crisis, as in previous crises, the large build-up of forex reserves by the major EMEs over the last decade has been a useful first-line of defence. In the absence of such war chests, more disruptive changes would have been forced on the EMEs. However, a prolonged period of large-scale intervention, as the sole policy response to manage large and growing volume of capital inflows, can create expectations of future exchange rate appreciation and runs the risk of creating distortions in the local financial system. There are, however, good grounds for believing such dangers can be reduced when forex intervention is combined with a policy orientation that allows currency flexibility over a medium term perspective in conjunction with continuous development and strengthening of the domestic financial sector, as has been the Indian approach.

\section{Transmission to Money Market Rates}

For monetary impulses to be transmitted to the real economy, money markets play a key role. Stability in money markets is critical for smooth transmission of monetary impulses to other financial markets and the rest of the economy. In this context, repo/reverse operations under the LAF manage transient liquidity shortfalls/surpluses in the money market. Apart from capital flows, another factor impacting short-term liquidity conditions is Government cash balances. There is lumpiness in tax inflows, which is witnessed every quarter. This is mainly on account of direct taxes. The lumpiness has been accentuated by the growing share of direct taxes in overall taxes. Advance tax flows at the end of every quarter lead to large withdrawal of liquidity from the banking system, putting upward pressure on money market rates. The combination of OMOs, MSS, CRR and LAF operations have enabled us to generally keep the overnight money market rates within the informal corridor provided by repo and reverse repo rates. 
In the aftermath of the failure of Lehman Brothers, various financial markets felt large pressures on the back of large FII outflows. There was a large demand for rupee liquidity from a variety of sources and money market rates rose beyond the upper band. The effective use of multiple instruments at the command of RBI to inject liquidity - successive cuts in CRR, redemption/buyback of MSS securities, cut in SLR and other windows - were successful and money market rates quickly fell within the corridor (Chart 10). While some pressure was felt in the money markets and other financial prices, the whole segment of financial markets continued to function normally. There was no loss of trust amongst the market players. Thus, overall, reasonable stability has been maintained in money markets. Our experience strongly supports the need for a central bank to have multiple instruments to manage the sudden vicissitudes in liquidity conditions.

Chart 10

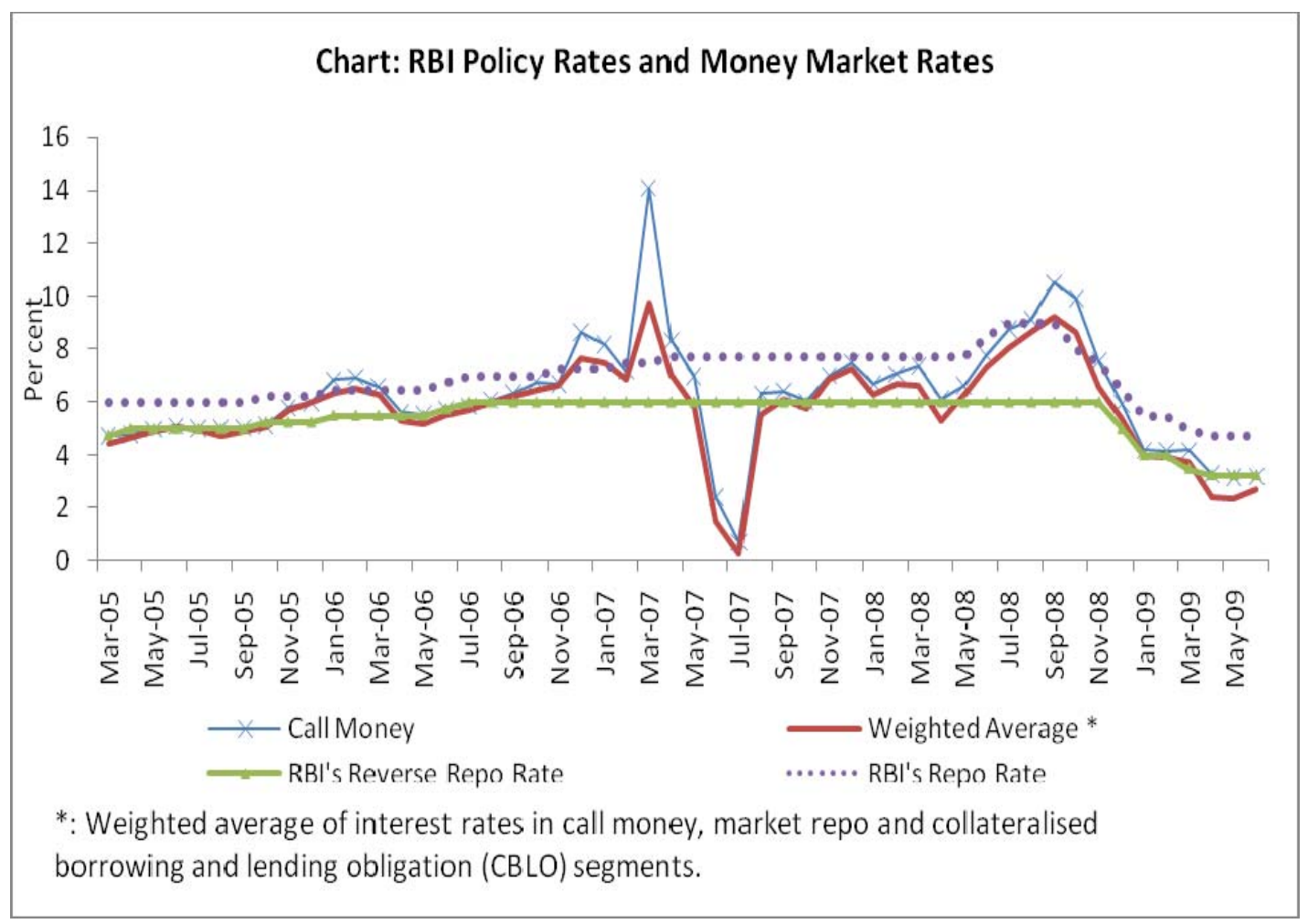




\section{Prudential Regulation and Financial Stability}

India's approach to the management of volatile capital flows has not been restricted to capital account management and foreign exchange intervention accompanied by appropriate sterilization. It has also been supplemented by the recognition that such flows can cause financial sector responses that need direct prudential regulation of financial intermediaries.

One cause of policy concern with excessive capital flows is that they encourage credit booms, especially in speculative activities, and can also create maturity and currency mismatches for banks. Various prudential measures have been taken to address this concern. First, banks access to external borrowings is subject to an overall ceiling, linked to their unimpaired Tier I capital. Second, debt liabilities in the form of NRI deposits are also managed through interest rate ceilings and minimum maturity requirements. Third, since high credit growth was observed in certain sectors such as real estate and stock markets, specific sectoral measures had to be undertaken. Prudential norms -provisioning norms and risk weights - were tightened during 2005-2007 in regard to these specific sectors. The prudential norms were rolled back in late 2008 in the aftermath of the global financial crisis (Tables 14 and 15). 
Table 14: Standard Asset Provisioning Requirements for Commercial Banks in India

\begin{tabular}{|c|c|c|c|c|c|c|}
\hline $\begin{array}{l}\text { Sr. } \\
\text { No. }\end{array}$ & Category of Standard Asset & $\begin{array}{r}\text { March } \\
2005\end{array}$ & $\begin{array}{r}\text { November } \\
2005\end{array}$ & $\begin{array}{l}\text { May } \\
2006\end{array}$ & $\begin{array}{r}\text { January } \\
2007\end{array}$ & $\begin{array}{r}\text { November } \\
2008\end{array}$ \\
\hline 1 & 2 & 3 & 4 & 5 & 6 & 7 \\
\hline 1. & Direct advances to the agricultural and SME sectors & 0.25 & 0.25 & 0.25 & 0.25 & 0.25 \\
\hline 2. & Residential housing loans beyond Rs. 2 million & 0.25 & 0.40 & 1.00 & 1.00 & 0.40 \\
\hline \multirow[t]{2}{*}{3.} & $\begin{array}{l}\text { Personal loans (including credit card receivables), } \\
\text { loans and advances qualifying as capital market }\end{array}$ & & & & & \\
\hline & exposures and commercial real estate loans & 0.25 & 0.40 & 1.00 & 2.00 & 0.40 \\
\hline 4. & $\begin{array}{l}\text { Loans and advances to non-deposit taking } \\
\text { systemically important non-banking finance } \\
\text { companies (NBFCs) }\end{array}$ & 0.25 & 0.40 & 0.40 & 2.00 & 0.40 \\
\hline 5. & All other loans and advances not included above & 0.25 & 0.40 & 0.40 & 0.40 & 0.40 \\
\hline
\end{tabular}

Source: Reserve Bank of India. 
Table 15: Risk Weight Requirements for Capital Adequacy

\begin{tabular}{|c|c|c|c|c|c|c|c|}
\hline Category of Asset & $\begin{array}{r}\text { March } \\
2006 \\
\end{array}$ & $\begin{array}{r}\text { May } \\
2006 \\
\end{array}$ & $\begin{array}{r}\text { September } \\
2006 \\
\end{array}$ & $\begin{array}{r}\text { January } \\
2007 \\
\end{array}$ & $\begin{array}{r}\text { May } \\
2007 \\
\end{array}$ & $\begin{array}{r}\text { May } \\
2008 \\
\end{array}$ & $\begin{array}{r}\text { November } \\
2008 \\
\end{array}$ \\
\hline 1 & 2 & 3 & 4 & 5 & 6 & 7 & 8 \\
\hline Commercial Real Estate & 125 & 150 & 150 & 150 & 150 & 150 & 100 \\
\hline Capital Market Exposure & 125 & 125 & 125 & 125 & 125 & 125 & 125 \\
\hline $\begin{array}{l}\text { Investment in Venture } \\
\text { capital funds }\end{array}$ & 100 & 150 & 150 & 150 & 150 & 150 & 150 \\
\hline Exposures to NBFC-ND-SI & 100 & 100 & 100 & 125 & 125 & 125 & 100 \\
\hline $\begin{array}{l}\text { Residential housing loans } \\
\text { extended to individuals } \\
\text { against mortgage of housing } \\
\text { properties (For loans up to } \\
\text { Rs. } 2 \text { million only) }\end{array}$ & 75 & 75 & 75 & 75 & 50 & * & * \\
\hline $\begin{array}{l}\text { Investments in MBS of } \\
\text { HFCs, recognized and } \\
\text { supervised by NHB }\end{array}$ & 75 & 75 & 75 & 50 & 50 & 50 & 50 \\
\hline $\begin{array}{l}\text { Exposure of banks to } \\
\text { entities to set up } \\
\text { SEZ/acquisition of units in } \\
\text { SEZ }\end{array}$ & 100 & 100 & 150 & 150 & 150 & 150 & 150 \\
\hline
\end{tabular}

\section{Note:}

*: Risk weights linked to loan-to-value (LTV) ratios as below:

\begin{tabular}{|l|l|c|}
\hline \multicolumn{1}{|c|}{ LTV Ratio } & Sanctioned Amount of Loan & Risk Weight \\
\hline$=$ or $<75 \%$ & Up to Rs.3 million & $50 \%$ \\
\hline$=$ or $<75 \%$ & Above Rs.3 million & $75 \%$ \\
\hline$>75 \%$ & Irrespective of the amount & $100 \%$ \\
\hline
\end{tabular}

NBFC-ND-SI: Non-Banking Financial Company - Non-Deposit taking - Systemically Important MBS: Mortgage Backed Securities; HFCs: Housing Finance Companies; NHB: National Housing Bank; SEZ: Special Economic Zones

Source: Reserve Bank of India

These measures appear to have moderated credit growth to commercial real estate to a certain extent from the very high levels of around 150 per cent (year-on-year) in late 2005 to around 50 per cent by 2008 (Chart 11). Whereas these measures were taken in a judgemental ad hoc manner in India, a more systematic approach to dynamic provisioning is now being internationally accepted and recommended. 
Such an integrated approach combining monetary and prudential instruments in India was facilitated by the fact that both monetary policy and financial regulation responsibilities have been entrusted to a single agency (Reserve Bank of India) (Mohan, 2009a; 2009c).

\section{Chart 11}

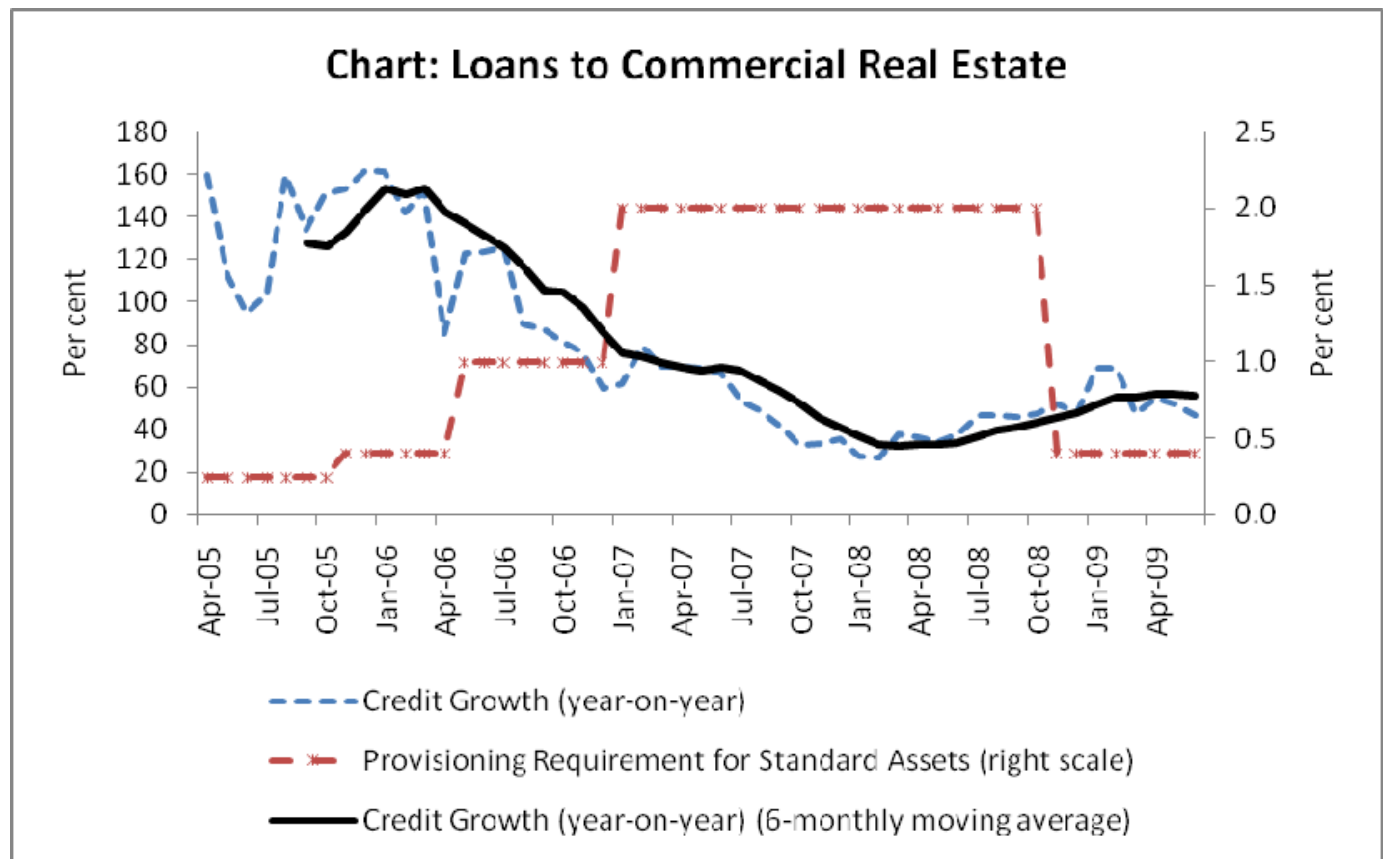

\section{Development and Regulation of Financial Markets}

In order to enhance monetary transmission as well as improve the efficiency in resource allocation, continuous actions have been taken by the Reserve Bank to deepen, widen and integrate various segments of financial market under its purview, while taking a cautious approach in regard to exotic instruments. Volatility in currency and bond markets can have significantly more adverse employment, output and distributional consequences compared to volatility in equity markets. Furthermore, interest rates and inflation rate in India remain higher that in major advanced economies and EMEs. Pre-mature liberalisation of money and 
bond markets can lead to large flows of hot money, which could exacerbate macroeconomic and monetary management. In recognition of these possible destabilising factors from cross-border developments, the liberalisation of domestic financial markets in India has been accompanied with prudential safeguards. Enhancing efficiency while at the same time, avoiding instability in the system, has been the challenge for the regulators in India. This approach to development and regulation of financial markets has imparted resilience to the financial markets, vividly reflected in their ability to withstand a series of financial crises including the latest global financial crisis.

Turnover in financial markets has seen a significant increase over the years. The bid-ask spread of Rupee/US\$ in the foreign exchange market has almost converged with that of other major currencies in the international market. On some occasions, in fact, the bid-ask spread of Rupee/US\$ market was lower than that of some major currencies (Mohan, 2007b). Currency futures were introduced in 2008, while interest rate futures were reintroduced in 2009. In contrast to developments in advanced economies, various segments of the financial market generally functioned normally in the aftermath of Lehman Brothers' failure.

Apart from banks, NBFCs and other financial institutions, RBI regulates the money market, the government securities market, the credit market and the foreign exchange market and the derivatives thereon. In respect of over-the-counter (OTC) derivatives, only those derivatives where one party to the transaction is an RBI regulated entity have legal validity. In respect of products traded on the exchanges, procedures for trade execution fall within the regulatory purview of Securities and Exchange Board of India (SEBI). Therefore, unlike many countries, India has had established procedures for regulation of OTC derivatives. 
The present arrangement of regulation of financial markets has demonstrated its efficacy over time, while it has also preserved financial stability. Nonetheless, there have been recommendations by two committees - High Powered Committee on Mumbai as an International Financial Centre (Chairman: Percy Mistry) (Government of India, 2007) and Committee on Financial Sector Reforms (Chairman: Raghuram Rajan) (Government of India, 2008) - that regulation of all trading of financial products and instruments be brought under SEBI. In this context, as noted earlier, unlike equity prices, interest rates and exchange rate are key macroeconomic variables with implications for monetary policy and overall macroeconomic stability. In addition, banks dominate the interest and exchange rate markets. By also being the regulator of these markets, the Reserve Bank is in a position to exercise oversight of institutions, markets and products, to monitor market developments, sense impending developments, take advance action, prevent excessive volatility and maintain financial stability at the systemic level (Subbarao, 2009). Similar arguments apply to calls for separation of banking regulation from monetary policy. Such recommendations were based on model that was prevalent in the UK and elsewhere. The crisis has questioned the merits of such a framework and these frameworks are being re-examined in these countries (Turner Review, 2009; Mohan, 2009c). In view of these factors, the advisability of entrusting regulation of all financial markets trading to an agency outside RBI needs to be revisited. In this context, it is relevant to note that globally banking supervision is mostly entrusted to central banks (Annex 5).

While changes in policy repo/reverse repo rates have emerged as a key instrument of monetary policy signalling, there are some impediments to their efficacy. First, financial markets are still not fully developed. Second, there are certain structural rigidities such as administered interest 
rates in respect of small savings (postal deposits and public provident fund etc) as well as for certain categories of borrowers (agriculture, export credit, and loans up to Rs.200,000). Third, although fiscal deficits had come down by 2007 , they were still high by international standards. Fiscal deficits and market borrowings have jumped substantially in the past couple of years under the impact of fiscal stimulus measures necessitated by the global financial crisis. Fiscal deficits are now at their highest levels. Finally, large and volatile capital flows have been a key driver of liquidity. In view of all these factors, along with policy rates, cash reserve ratio remains an important instrument of monetary and liquidity management. While the long-run policy objective continues to be to reduce it to 3 per cent, it is considered desirable and prudent to use CRR to reinforce the effectiveness of policy rates.

This review of Indian monetary policy operations and associated financial sector regulatory measures has illustrated the complexity in overall macro and financial management that has had to be practised in the face of volatile capital flows. How successful have these policy operations been in achieving the objective of ensuring an adequate growth momentum in the economy while preserving price and financial stability? It is to the documentation of these outcomes that we now turn. 


\section{OUTCOMES: WAS MONETARY POLICY INDEPENDENT?}

\section{Reserve Money, Credit and Money Supply}

A common concern with foreign exchange market interventions is that they can lead to excessive expansion in monetary aggregates, and turn out to be inflationary. What has been the Indian experience in this regard? While volatility in capital flows has posed continuous challenges to monetary policy, the flexible usage of various sterilisation and liquidity management instruments ensured that growth in monetary and credit aggregates was largely consistent with requirements of the real economy. There was, however, some acceleration in monetary and credit growth during 2004-08, the period of enhanced capital flows, particularly that in credit growth. While it partly reflected the impact of capital inflows, it was also the outcome of increased real demand arising from strong real activity: real GDP growth accelerated to an average of 9.0 per cent during the 5-year period 2003-08 from 5.7 per cent during the preceding 5-year period (1998-2003) (Table 16). 
Table 16: Capital Flows and Monetary Management

\begin{tabular}{|c|c|c|c|c|c|c|c|}
\hline \multirow[b]{2}{*}{ Year } & \multirow{2}{*}{$\begin{array}{r}\text { Capital } \\
\text { Inflows } \\
\text { (net) } \\
\text { (US \$ } \\
\text { billion) }\end{array}$} & \multirow{2}{*}{$\begin{array}{r}\text { RBI's } \\
\text { Purchase }(+) / \\
\text { Sale(-) of Foreign } \\
\text { Exchange (US \$ } \\
\text { billion) }\end{array}$} & \multicolumn{4}{|c|}{$\begin{array}{c}\text { Variation in Monetary and Credit } \\
\text { Aggregates (Per cent) }\end{array}$} & \multirow{2}{*}{$\begin{array}{l}\text { Real } \\
\text { GDP } \\
\text { Growth } \\
\text { (Per } \\
\text { cent) }\end{array}$} \\
\hline & & & $\begin{array}{r}\text { Reserve } \\
\text { Money }\end{array}$ & $\begin{array}{r}\text { Reserve } \\
\text { Money } \\
\text { (adjusted } \\
\text { for CRR) }\end{array}$ & $\begin{array}{r}\text { Money } \\
\text { supply } \\
\text { (M3) }\end{array}$ & $\begin{array}{c}\text { Bank } \\
\text { Credit } \\
\text { (Non- } \\
\text { food) } \\
\end{array}$ & \\
\hline 1 & 2 & 3 & 4 & 5 & 6 & 7 & 8 \\
\hline $1989-90$ & 7.0 & n.a & 23.2 & & 19.4 & 18.5 & 6.1 \\
\hline $1990-91$ & 7.2 & n.a & 13.1 & & 15.1 & 12.4 & 5.3 \\
\hline 1991-92 & 3.8 & n.a & 13.4 & & 19.3 & 8.2 & 1.4 \\
\hline $1992-93$ & 2.9 & n.a & 11.3 & & 14.8 & 20.1 & 5.4 \\
\hline $1993-94$ & 9.7 & n.a & 25.2 & & 18.4 & 5.7 & 5.7 \\
\hline 1994-95 & 9.2 & n.a & 22.1 & & 22.4 & 29.8 & 6.4 \\
\hline $1995-96$ & 4.7 & n.a & 14.9 & & 13.6 & 22.5 & 7.3 \\
\hline $1996-97$ & 11.4 & 7.8 & 2.8 & & 16.2 & 10.9 & 8.0 \\
\hline $1997-98$ & 10.0 & 3.8 & 13.2 & & 18.0 & 15.1 & 4.3 \\
\hline 1998-99 & 8.3 & 1.8 & 14.5 & & 19.4 & 13.0 & 6.7 \\
\hline $1999-2000$ & 11.1 & 3.2 & 8.2 & & 14.6 & 16.5 & 6.4 \\
\hline $2000-01$ & 8.5 & 2.4 & 8.1 & & 16.8 & 14.9 & 4.4 \\
\hline 2001-02 & 8.4 & 7.1 & 11.4 & & 14.1 & 13.6 & 5.8 \\
\hline $2002-03$ & 10.6 & 15.7 & 9.2 & & 14.7 & 26.9 & 3.8 \\
\hline $2003-04$ & 17.3 & 30.5 & 18.3 & 19.2 & 16.7 & 18.4 & 8.5 \\
\hline 2004-05 & 28.6 & 20.8 & 12.1 & 10.0 & 11.8 & 27.5 & 7.5 \\
\hline $2005-06$ & 30.5 & 8.1 & 16.9 & 16.9 & 16.9 & 31.8 & 9.5 \\
\hline $2006-07$ & 46.4 & 26.8 & 23.9 & 19.1 & 21.7 & 28.5 & 9.7 \\
\hline 2007-08 & 108.0 & 78.2 & 31.0 & 25.3 & 21.4 & 23.0 & 9.0 \\
\hline 2008-09 & 8.0 & -34.9 & 6.4 & 19.0 & 18.6 & 17.8 & 6.7 \\
\hline
\end{tabular}

n.a: not available

Source: Reserve Bank of India

The higher acceleration in credit growth relative to that of broad money supply (M3) was enabled by the drawdown of excess initial stocks of government securities in banks' balance sheets. During the period of the cyclical economic slowdown (1998-2003), the banks had exhibited a preference for investing in risk free government security assets rather than doing commercial lending, thereby accumulating stocks of government securities far in excess of the required SLR of 25 per cent. 
As credit growth accelerated beginning 2002-03 onwards, banks divested their excess SLR investments to meet credit demand. Accordingly, growth in credit was higher than that in money supply. Thus, higher credit growth was also due to leeway provided by excess SLR holdings (Chart 12).

Chart 12

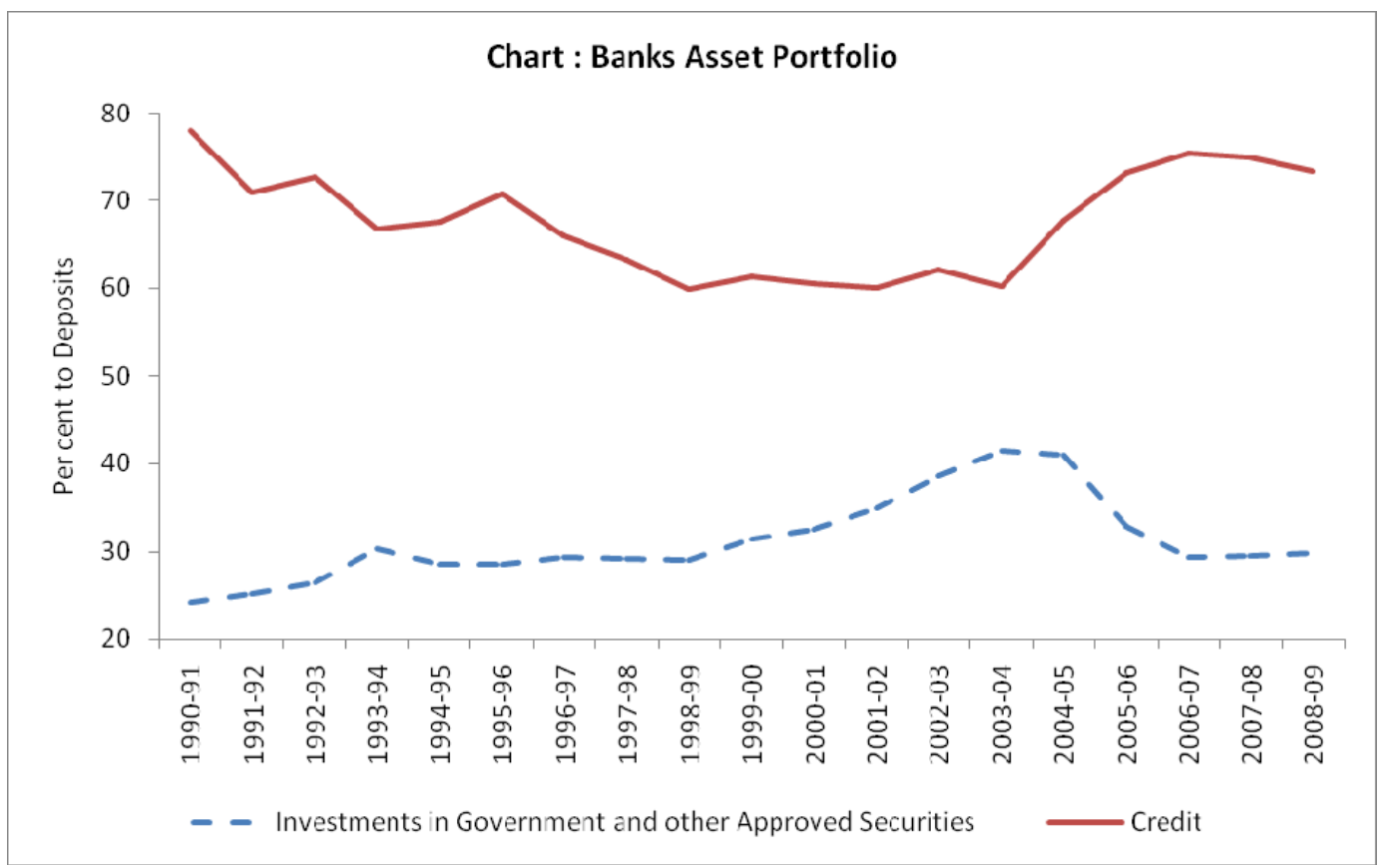

It is important to stress that unlike many other central banks, where monetary and credit aggregates have seen benign neglect, these variables remain important information variables in RBI's conduct of monetary policy. During the episode of high growth in monetary and credit aggregates, the Reserve Bank in its monetary policy statements opined that that high growth in such aggregates, in conjunction with other demand indicators, was indicative of possible overheating of the economy. Accordingly, at the aggregate level, credit and monetary growth was restrained through tightening of policy rates and absorption of liquidity 
through CRR, MSS and OMOs. In addition, sectoral concerns over high credit growth in specific sectors such as real estate, as noted earlier, were addressed through tightening of prudential norms.

Although there was strong growth in credit and monetary aggregates during 2004-08, managing such aggregates at the appropriate rate of

growth poses challenges for monetary authorities in EMEs such as India. During a period of rapid growth, change in traditional estimates of money multipliers is difficult to predict in the presence of financial deepening. For example, the credit GDP ratio should be expected to rise, as new entities get financed and hitherto excluded segments of the population get access to and start using banking services. Therefore, as the growth process strengthens and becomes more inclusive, it is expected that demand for financial products would continue to witness high growth in the coming years. If so, growth in bank credit and monetary aggregates could be higher than what might be expected from historical relationships and estimated elasticities in view of ongoing structural changes. This raises critical issues for the central bank such as the appropriate order of monetary/credit expansion. Thus, the Reserve Bank will have to face ongoing challenges to provide appropriate liquidity to the system so as to ensure growth in non-inflationary environment. This raises the critical issues of clarity in reading signs of inflation, asset prices and systemic liquidity from monetary/credit expansion (Mohan 2008 b).

\section{Reserve Money and CRR: Analytics}

In analysing the growth in reserve (bank) money $\left(\mathrm{M}_{0}\right)$, it is misleading to draw conclusions from the headline numbers. During the periods of large capital inflows that led to large forex interventions by the RBI, as part of the sterilization strategy, liquidity was impounded, inter alia, through increases in the Cash Reserve Ratio (CRR) mandating banks to maintain 
higher proportions of their liabilities as reserves (unremunerated since 2007) with the Reserve Bank. Increases in CRR, even as they impound excess liquidity from the banking system, end up showing a higher expansion in reserve money and the Reserve Bank's balance sheet. Broad money expansion is constrained since this results in reduction of the money multiplier, with CRR balances being impounded and not being available for credit expansion with the banks. Furthermore, since CRR balances are no longer remunerated, banks do not maintain large excess reserves ${ }^{10}$. Banks prefer to park excess funds in reverse repos under the LAF (see Chart). Thus, CRR balances almost fully reflect impounded reserves. Nonetheless, as CRR is raised, reserve money growth is observed to be higher. The reverse happens when the CRR is cut. During 2004-08, reserve money growth was overstated because of CRR. The situation has reversed since October 2008: due to reduction in CRR, growth in headline reserve money is lower, even though banks have been provided with greater liquidity that can be used for lending or investment.

It is, therefore, important to analyse variations in reserve money adjusted for the impact of policy-induced changes in CRR. It is because of the accounting conventions that the Reserve Bank reports data for increase in reserve money, net of the CRR impact. Such an analysis shows that growth in reserve money has been relatively stable even as net foreign assets had shown large increase/decrease (Table 16). In view of the above, the observations of various analysts [e.g. Shah and Patnaik (2008); Grenville (2008)] that incomplete sterilisation in the post-2004 period led to acceleration in reserve money growth is mistaken. Moreover, Grenville uses variation in net foreign assets and not actual market interventions data to reach conclusions on growth of base money.

\footnotetext{
${ }^{10}$ Prior to the 2007 amendment to the RBI Act, only required reserves were remunerated. Excess reserves were not remunerated even at that time.
} 
Variation in net foreign assets includes both market sale/purchase of foreign exchange and also changes due to valuation which can be sizable. There are periods when net foreign assets vary even though there have been no market interventions. It is only the variation in market purchases of foreign exchange by the central bank that have implications for reserve money, not the variation in the stock of foreign assets. At times, net foreign assets and market purchases can move in opposite directions; for example, during 2008-09, net foreign assets of the Reserve Bank increased by Rs.440 billion, while the Reserve Bank actually sold foreign exchange worth Rs. 1,786 billion during the year. More generally, data nuances need to be understood carefully. Many other countries also use cash reserve ratios. Cross-country studies typically take headline reserve money growth in their analysis and run the risk of reaching wrong conclusions.

\section{Financial Sector Development: Growth with Enhanced Efficiency and Stability}

Strong export growth, jump in domestic savings and investment, strengthening of the financial sector, deepening and widening of financial markets have also been witnessed in the recent years. Domestic savings jumped from 24.8 per cent of GDP in 1999-2000 to 37.7 per cent in 200708, while investment rate rose from 25.9 per cent of GDP to 39.1 per cent over the same period. Non-performing assets fell from 6.8 per cent of net advances (March 2000) to 1.1 per cent (March 2009), despite tightening of recognition norms towards the international standard of 90 days. Capital to risk-weighted assets ratio (CRAR) improved from 11.3 per cent (March 2000) to 13.2 per cent (March 2009) (Table 17). All commercial banks, as noted earlier, are Basel II compliant as of April 2009. Reflecting the strength of the banking system, confidence in the Indian banking system has been maintained since the early 1990s, even in the current episode of 
severe financial turmoil. Unlike other major advanced economies and also economies in the Asian region, no need was felt for enhancing deposit insurance or guaranteeing deposits and liabilities. Overall, financial stability could be maintained.

Table 17: Key Indicators of Scheduled Commercial Banks in India

\begin{tabular}{lrrrrr}
\hline Item & 2004-05 & 2005-06 & 2006-07 & 2007-08 & 2008-09 \\
\hline 1 & 2 & 3 & 4 & 5 & 6 \\
\hline $\begin{array}{l}\text { Capital to Risk-weighted Assets } \\
\text { Ratio (CRAR) (per cent) }\end{array}$ & 12.8 & 12.3 & 12.3 & 13.0 & 13.2 \\
$\begin{array}{l}\text { Of which: Tier I CRAR (per cent) } \\
\text { Net Non-Performing Assets (per }\end{array}$ & 8.4 & 9.3 & 8.3 & 9.1 & n.a. \\
cent to net advances) & 1.9 & 1.2 & 1.0 & 1.1 & 1.1 \\
$\begin{array}{l}\text { Net Non-Performing Assets (per } \\
\text { cent to assets) }\end{array}$ & 0.9 & 0.7 & 0.6 & 0.6 & n.a. \\
Net profits (per cent to assets) & 0.9 & 0.9 & 0.9 & 1.0 & 1.0 \\
Net interest margin (per cent to & 2.8 & 2.8 & 2.6 & 2.3 & 2.4 \\
assets) & & & & & \\
\hline
\end{tabular}

Source: Report on Trend and Progress, 2007-08, Reserve Bank of India; Annual Report, 2008-09.

There has been an all-round improvement in the productivity/efficiency of the banking sector since 2001-02 (RBI, 2008). Various efficiency/productivity and soundness parameters have moved closer to the global levels. The most significant improvement has taken place in the performance of public sector banks, as a result of which the performance of various bank groups has now converged with that of foreign banks and new private sector banks in respect of most of the parameters. The intermediation cost as also the net interest margin declined across the bank groups. Despite this, however, the profitability of the banking sector improved. Thus, it is not the higher interest rate spreads but rather 
increased efficiency that led to higher profitability. Efficiency and productivity based on economic measures corroborate the findings of the accounting measures or financial ratios. Efficiency has improved across all bank groups when measured from a grand frontier for all banks for the period 1991-92 to 2006-07 and most of these efficiency gains have emanated after few years of reforms, i.e., from 1997-98 onwards.

Overall, the Indian financial sector has transformed into a reasonably sophisticated, diverse and resilient system delivering a wide variety of financial services efficiently and profitably, with a spectrum of financial market segments in which financial institutions are able to participate with operational and functional autonomy in an environment of increasing deregulation and international competition. The financial system has served well the overall needs of the economy while containing risk and entrenching financial stability. The process of "Schumpeterian creative destruction" (Mistry Committee Report, Government of India, 2007), although appropriate for non-financial firms, is not strictly applicable to the banking sector, as again forcefully shown by the global financial crisis. The mechanical application of "Schumpeterian creative destruction" principle to the banking industry can lead to systemic instability with severe consequences for the real economy.

\section{Money Supply, Credit and Inflation: Cross-Country Comparisons}

In the context of sterilisation operations, it is often argued that it leads to loss of control over monetary aggregates. Recent cross-country experience does not seem to support such a hypothesis. Countries which reportedly do not intervene in the foreign exchange markets - such as Australia, UK, US - as well as those which have adopted an inflation targeting framework - such as Chile, Colombia, Czech Republic, Indonesia, Peru, Poland and South Africa - all witnessed acceleration in 
growth in broad money during this decade (Table 18) ${ }^{11}$. Similar trends can be observed in the case of credit growth (Table 19). In fact there was an all round significant increase in broad money and credit growth in most advanced economies from around 2005, which should have served as early warning signals of the problems that emerged later.

${ }^{11}$ Classification of countries into emerging market economies and advanced economies in Tables 18-21 is based on the classification adopted by the IMF in its World Economic Outlook. 
Table 18: Broad Money: Cross-Country Comparison

\begin{tabular}{|c|c|c|c|c|c|c|c|}
\hline \multirow[b]{2}{*}{ Country } & \multirow[b]{2}{*}{2002} & \multirow[b]{2}{*}{2003} & \multirow[b]{2}{*}{2004} & \multirow[b]{2}{*}{2005} & \multicolumn{3}{|c|}{ (Annual growth in per cent) } \\
\hline & & & & & \multirow{2}{*}{$\begin{array}{r}2006 \\
6 \\
\end{array}$} & \multirow{2}{*}{$\begin{array}{r}2007 \\
7\end{array}$} & \multirow{2}{*}{$\begin{array}{r}2008 \\
8 \\
\end{array}$} \\
\hline 1 & 2 & 3 & 4 & 5 & & & \\
\hline \multicolumn{8}{|c|}{ Emerging Market Economies } \\
\hline Argentina & 19.7 & 29.6 & 21.4 & 21.5 & 20.3 & 24.5 & 8.0 \\
\hline Brazil (1999) & 9.9 & 20.5 & 16.6 & 19.2 & 18.6 & 18.4 & 18.0 \\
\hline Chile (1999) & 6.1 & -0.5 & 9.6 & 9.9 & 20.6 & 18.8 & 10.8 \\
\hline China,P.R.: Mainland & 13.1 & 19.2 & 14.9 & 16.7 & 22.1 & 16.7 & 17.8 \\
\hline Colombia (1999) & 4.6 & 10.6 & 19.2 & 17.6 & 18.0 & 17.4 & 18.5 \\
\hline Guatemala (1991) & 7.5 & 43.0 & 10.9 & 13.8 & 13.4 & 9.8 & 5.9 \\
\hline Hungary (2001) & 14.1 & 12.5 & 8.9 & 13.5 & 14.1 & 9.5 & 9.4 \\
\hline India & 14.7 & 16.7 & 11.8 & 16.9 & 21.7 & 21.4 & 18.6 \\
\hline Indonesia (2005) & 4.8 & 8.4 & 8.7 & 16.3 & 14.9 & 19.3 & 14.9 \\
\hline Latvia & 19.9 & 22.1 & 26.7 & 38.3 & 38.7 & 13.5 & -4.0 \\
\hline Malaysia & 4.8 & 8.6 & 12.7 & 8.8 & 13.6 & 7.9 & 10.5 \\
\hline Mexico (2001) & 5.1 & 9.3 & 13.0 & 10.0 & 6.7 & 10.1 & 8.9 \\
\hline Peru (2002) & 5.1 & -2.4 & 3.1 & 16.8 & 11.8 & 23.0 & 23.2 \\
\hline Philippines (2002) & 10.4 & 3.6 & 9.9 & 6.4 & 19.6 & 5.4 & n.a. \\
\hline Poland (1998) & -2.0 & 5.4 & 7.7 & 12.8 & 14.8 & 13.0 & 19.1 \\
\hline Romania (2005) & 46.6 & 21.1 & 48.4 & 20.0 & 14.1 & 33.7 & 17.6 \\
\hline Russia & 33.8 & 38.5 & 33.7 & 36.3 & 40.5 & 44.2 & 14.6 \\
\hline South Africa (2000) & 7.6 & 13.4 & 13.2 & 20.7 & 22.6 & 23.4 & 15.7 \\
\hline Thailand (2000) & 3.8 & 4.8 & 5.6 & 6.1 & 8.1 & 6.2 & 9.2 \\
\hline Turkey (2006) & 28.6 & 14.4 & 20.8 & 35.8 & 22.2 & 15.2 & 24.9 \\
\hline \multicolumn{8}{|c|}{ Advanced Economies } \\
\hline Australia (1993) & 5.6 & 12.8 & 11.4 & 8.6 & 15.0 & 29.9 & 14.9 \\
\hline Canada (1991) & 2.7 & 0.5 & 5.5 & 9.8 & 12.6 & -25.3 & 15.1 \\
\hline China,P.R.:Hong Kong & 0.5 & 6.3 & 7.3 & 3.5 & 16.2 & 18.8 & 4.2 \\
\hline Czech Republic (1997) & -2.1 & 7.4 & 4.4 & 8.4 & 9.9 & 12.8 & 8.5 \\
\hline Euro area & 6.8 & 6.9 & 6.6 & 7.5 & 10.0 & 11.4 & 7.4 \\
\hline Iceland & 15.0 & 22.4 & 13.5 & 29.3 & 60.1 & n.a. & n.a. \\
\hline Israel (1997) & 6.9 & -0.1 & 3.6 & 11.2 & 5.1 & 8.0 & n.a. \\
\hline Korea (1998) & 11.0 & 6.7 & -0.6 & 3.1 & 4.4 & 0.3 & 15.9 \\
\hline Japan & 0.9 & 0.5 & 0.6 & 0.5 & -0.7 & 0.7 & 0.7 \\
\hline New Zealand (1989) & 7.7 & 10.6 & 5.6 & 11.4 & 7.8 & 10.9 & 12.4 \\
\hline Switzerland & 5.7 & 8.4 & 2.9 & 6.8 & 4.9 & 3.3 & 3.0 \\
\hline United Kingdom (1992) & 5.0 & 9.8 & 9.8 & 13.8 & 14.1 & 15.8 & 17.3 \\
\hline United States & 4.5 & 4.4 & 5.6 & 8.2 & 9.4 & 12.1 & 8.4 \\
\hline
\end{tabular}

Source: International Financial Statistics (June 2009 CD-ROM), IMF; Reserve Bank of India; European Central Bank.

Note: For inflation targeting (IT) countries, the year of adoption of IT is given in parenthesis (Source: Hammond (2009).

n.a.: not available. 
Table 19: Bank Credit: Cross-Country Comparison

\begin{tabular}{|c|c|c|c|c|c|c|c|}
\hline \multirow[b]{2}{*}{ Country } & \multirow[b]{2}{*}{2002} & \multirow[b]{2}{*}{2003} & \multirow[b]{2}{*}{2004} & \multicolumn{4}{|c|}{ (Annual growth in per cent) } \\
\hline & & & & 2005 & 2006 & 2007 & 2008 \\
\hline 1 & 2 & 3 & 4 & 5 & 6 & 7 & 8 \\
\hline \multicolumn{8}{|c|}{ Emerging Market Economies } \\
\hline Argentina & -12.8 & -15.5 & 15.4 & 31.7 & 36.1 & 37.0 & 20.1 \\
\hline Brazil (1999) & 15.7 & 7.8 & 14.9 & 19.3 & 25.7 & 36.6 & 30.1 \\
\hline Chile (1999) & 8.2 & 6.2 & 15.2 & 16.0 & 15.8 & 21.0 & 18.6 \\
\hline China,P.R.: Mainland & 17.2 & 20.8 & 11.2 & 9.1 & 14.3 & 19.3 & 14.0 \\
\hline Colombia (1999) & 6.2 & 8.8 & 29.8 & 11.3 & 38.5 & 23.5 & 15.9 \\
\hline Guatemala (1991) & 4.6 & 33.3 & 9.2 & 25.0 & 18.0 & 26.3 & -12.6 \\
\hline Hungary (2001) & 19.2 & 33.6 & 18.6 & 18.9 & 16.7 & 18.8 & 18.5 \\
\hline India & 26.9 & 18.4 & 27.5 & 31.8 & 28.5 & 23.0 & 17.8 \\
\hline Indonesia (2005) & 16.0 & 19.2 & 31.1 & 21.0 & 12.1 & 22.4 & 30.7 \\
\hline Latvia & 36.5 & 37.3 & 46.8 & 63.6 & 58.3 & 34.0 & 11.8 \\
\hline Malaysia & 2.6 & 6.7 & 6.5 & 9.1 & 6.8 & 9.2 & 10.4 \\
\hline Mexico (2001) & 19.8 & 7.4 & 7.0 & 17.8 & 30.8 & 18.0 & 1.9 \\
\hline Peru (2002) & -0.5 & -4.7 & -0.3 & 16.5 & 6.3 & 31.3 & 32.8 \\
\hline Philippines (2002) & 0.8 & 1.1 & 9.3 & -2.2 & 7.4 & 4.8 & n.a. \\
\hline Poland (1998) & 4.3 & 6.7 & 10.0 & 9.3 & 24.0 & 31.5 & 36.4 \\
\hline Romania (2005) & 51.2 & 76.6 & 42.4 & 49.0 & 54.9 & 62.4 & 34.0 \\
\hline Russia & 30.1 & 44.7 & 48.2 & 35.2 & 49.5 & 50.9 & 36.4 \\
\hline South Africa (2000) & -12.4 & 18.1 & 14.6 & 17.0 & 25.4 & 22.0 & 10.0 \\
\hline Thailand (2000) & 12.3 & 6.4 & 11.3 & 8.0 & 4.5 & 4.8 & 8.8 \\
\hline Turkey (2006) & 38.0 & 30.0 & 46.0 & 49.5 & 36.3 & 26.4 & 24.6 \\
\hline \multicolumn{8}{|c|}{ Advanced Economies } \\
\hline Australia (1993) & 10.4 & 15.4 & 11.4 & 13.2 & 13.2 & 17.4 & 12.8 \\
\hline Canada (1991) & 1.3 & 1.0 & 8.5 & 12.2 & 16.1 & -2.9 & 5.5 \\
\hline China,P.R.:Hong Kong & -4.0 & -2.8 & 3.7 & 6.0 & 1.8 & 9.7 & 6.2 \\
\hline Czech Republic (1997) & -20.7 & 7.9 & 12.0 & 20.1 & 19.9 & 28.3 & 14.8 \\
\hline Euro area & 4.7 & 5.8 & 7.1 & 9.5 & 11.5 & 12.8 & 7.1 \\
\hline Iceland & 11.2 & 27.7 & 39.6 & 66.1 & 46.8 & n.a. & n.a. \\
\hline Israel (1997) & 9.4 & -3.6 & 4.3 & 11.9 & 3.8 & 8.3 & 7.6 \\
\hline Korea (1998) & 19.6 & 8.7 & 1.3 & 7.4 & 14.7 & 12.4 & 14.9 \\
\hline Japan & -7.8 & -3.9 & -2.3 & 3.8 & -0.1 & -0.2 & 1.1 \\
\hline New Zealand (1989) & 7.2 & 10.0 & -4.7 & 16.2 & 15.4 & 15.1 & 13.4 \\
\hline Switzerland & 0.3 & 3.6 & 4.3 & 6.4 & 9.1 & 8.8 & -1.0 \\
\hline United Kingdom (1992) & 8.4 & 9.7 & 11.2 & 10.4 & 13.3 & 16.0 & 15.8 \\
\hline United States & 3.6 & 7.2 & 10.6 & 10.6 & 9.5 & 9.2 & 2.1 \\
\hline
\end{tabular}

Source: International Financial Statistics (June 2009 CD-ROM), IMF; Reserve Bank of India; European Central Bank.

Note: For inflation targeting (IT) countries, the year of adoption of IT is given in parenthesis (Source: Hammond (2009).

For India, data pertain to non-food credit by scheduled commercial banks.

n.a.: not available. 
Analytically, it is not clear as to why money supply and credit will not accelerate in countries that do not intervene. If such countries face large capital inflows, then in the absence of central bank intervention, such flows will get intermediated by the banking system. These will then get reflected in credit and monetary aggregates. On the contrary, sterilisation can help contain excessive growth in monetary aggregates. If sterilisation is ineffective, it could be the result of the absence of adequate instruments with the central bank. Of course, sterilisation should not be seen as the sole instrument of capital account management. Rather, it is most effective when it is deployed in conjunction with the use of other instruments, including for capital account management, a flexible exchange rate, financial market development and fiscal prudence.

\section{Inflation}

Active management of capital flows, effective sterilisation of foreign exchange market interventions and judicious use of the menu of monetary instruments is reflected in final objectives of inflation and growth. Inflation in India since the mid-1990s has been significantly lower than in the preceding three decades. Inflation has averaged around 5 per cent since mid-1990s as compared with around 8 per cent during the preceding three decades (Chart 13). Inflation in India over the recent years has been comparable to those in other emerging market economies. Inflation did rise, however, in 2007 and 2008 because of higher food and fuel prices as in many other economies (Table 20). Thus, there is no evidence that multiple objectives hampered pursuit of price stability. In this context, India monetary policy performed about as well as inflation targeting EMEs. 
Chart 13

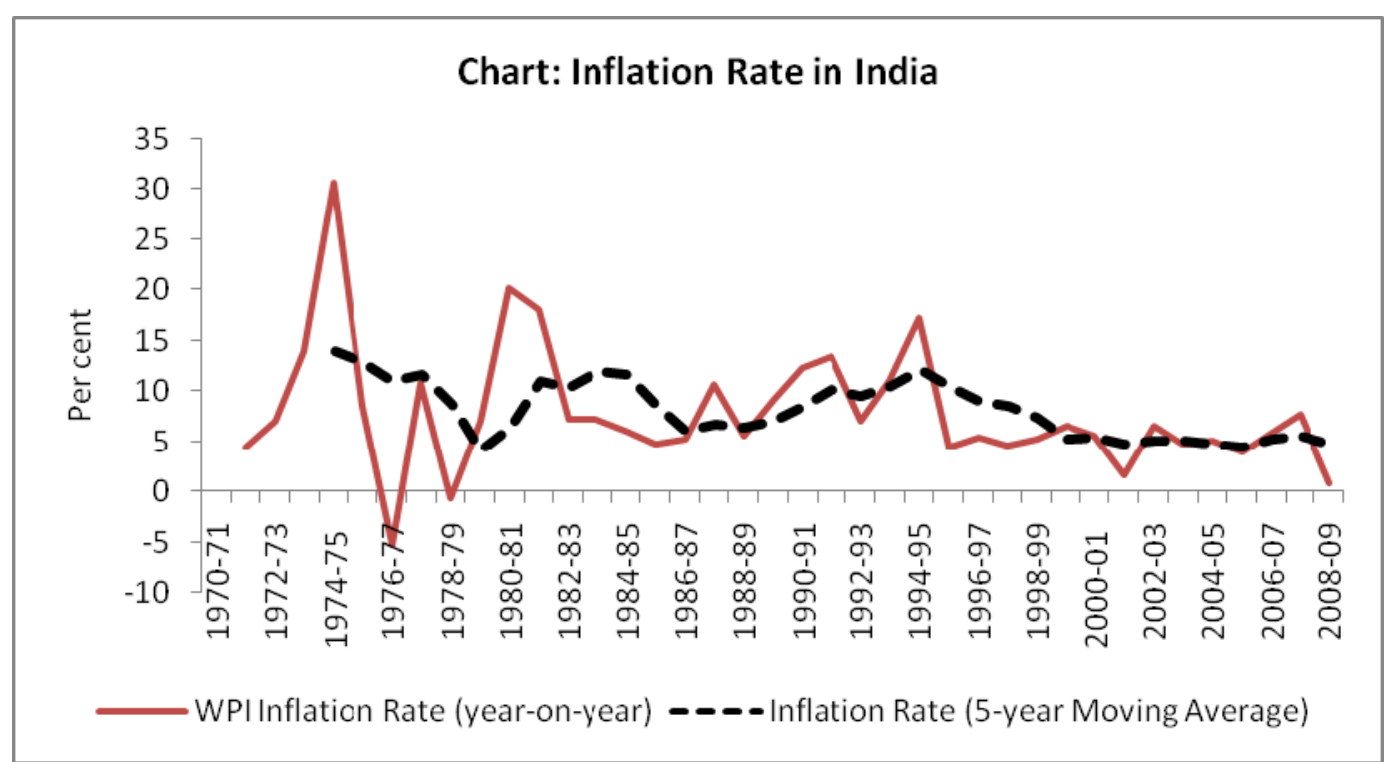


Table 20: Consumer Price Inflation: Cross-Country Comparison

\begin{tabular}{|c|c|c|c|c|c|c|c|}
\hline Country & 2002 & 2003 & 2004 & 2005 & 2006 & 2007 & 2008 \\
\hline 1 & 2 & 3 & 4 & 5 & 6 & 7 & 8 \\
\hline \multicolumn{8}{|c|}{ Emerging Market Economies } \\
\hline Argentina & 25.9 & 13.4 & 4.4 & 9.6 & 10.9 & 8.8 & 8.6 \\
\hline Brazil (1999) & 8.5 & 14.7 & 6.6 & 6.9 & 4.2 & 3.6 & 9.8 \\
\hline Chile (1999) & 2.5 & 2.8 & 1.1 & 3.1 & 3.4 & 4.4 & 8.7 \\
\hline China,P.R.: Mainland & -0.8 & 1.2 & 3.9 & 1.8 & 1.5 & 4.8 & 5.9 \\
\hline Colombia (1999) & 6.4 & 7.1 & 5.9 & 5.0 & 4.3 & 5.5 & 7.0 \\
\hline Guatemala (1991) & 6.3 & 5.9 & 9.2 & 8.6 & 5.8 & 8.7 & 6.7 \\
\hline Hungary (2001) & 5.3 & 4.6 & 6.8 & 3.6 & 3.9 & 7.9 & 6.1 \\
\hline India & 4.4 & 3.8 & 3.8 & 4.2 & 5.8 & 6.4 & 8.4 \\
\hline Indonesia (2005) & 11.9 & 6.6 & 6.2 & 10.5 & 13.1 & 6.3 & 10.1 \\
\hline Latvia & 1.9 & 3.0 & 6.2 & 6.7 & 6.5 & 10.1 & 15.4 \\
\hline Malaysia & 1.8 & 1.0 & 1.5 & 3.0 & 3.6 & 2.0 & 5.4 \\
\hline Mexico (2001) & 5.0 & 4.5 & 4.7 & 4.0 & 3.6 & 4.0 & 5.1 \\
\hline Peru (2002) & 0.2 & 2.3 & 3.7 & 1.6 & 2.0 & 1.8 & 6.6 \\
\hline Philippines (2002) & 10.0 & 3.5 & 6.0 & 7.6 & 6.2 & 2.8 & 9.3 \\
\hline Poland (1998) & 1.9 & 0.8 & 3.6 & 2.1 & 1.1 & 2.4 & 4.3 \\
\hline Romania (2005) & 22.5 & 15.3 & 11.9 & 9.0 & 6.6 & 4.8 & 7.8 \\
\hline Russia & 15.8 & 13.7 & 10.9 & 12.7 & 9.7 & 9.0 & 14.1 \\
\hline South Africa (2000) & 9.2 & 5.6 & -0.9 & 2.1 & 3.2 & 6.1 & 9.8 \\
\hline Thailand (2000) & 0.7 & 1.8 & 2.8 & 4.5 & 4.6 & 2.2 & 5.5 \\
\hline Turkey (2006) & 45.0 & 25.3 & 10.6 & 10.1 & 10.5 & 8.8 & 10.4 \\
\hline \multicolumn{8}{|c|}{ Advanced Economies } \\
\hline Australia (1993) & 3.0 & 2.8 & 2.3 & 2.7 & 3.5 & 2.3 & 4.4 \\
\hline Canada (1991) & 2.3 & 2.8 & 1.9 & 2.2 & 2.0 & 2.1 & 2.4 \\
\hline China,P.R.:Hong Kong & -3.1 & -2.5 & -0.4 & 0.9 & 2.0 & 2.0 & 4.3 \\
\hline Czech Republic (1997) & 1.8 & 0.1 & 2.8 & 1.8 & 2.5 & 2.9 & 6.4 \\
\hline Euro area & 2.3 & 2.1 & 2.1 & 2.2 & 2.2 & 2.1 & 3.3 \\
\hline Iceland & 5.2 & 2.1 & 2.8 & 4.2 & 6.7 & 5.1 & 12.7 \\
\hline Israel (1997) & 5.7 & 0.7 & -0.4 & 1.3 & 2.1 & 0.5 & 4.6 \\
\hline Korea (1998) & 2.8 & 3.5 & 3.6 & 2.8 & 2.3 & 2.5 & 4.7 \\
\hline Japan & -0.9 & -0.2 & 0.0 & -0.3 & 0.2 & 0.1 & 1.4 \\
\hline New Zealand (1989) & 2.7 & 1.8 & 2.3 & 3.0 & 3.4 & 2.4 & 4.0 \\
\hline Switzerland & 0.6 & 0.6 & 0.8 & 1.2 & 1.1 & 0.7 & 2.4 \\
\hline United Kingdom (1992) & 1.6 & 2.9 & 3.0 & 2.8 & 3.2 & 4.3 & 4.0 \\
\hline United States & 1.6 & 2.3 & 2.7 & 3.4 & 3.2 & 2.9 & 3.8 \\
\hline \multicolumn{8}{|l|}{ Memo: } \\
\hline World & 3.5 & 3.8 & 3.7 & 3.8 & 3.6 & 3.9 & 5.9 \\
\hline Advanced Economies & 1.5 & 1.9 & 2.1 & 2.3 & 2.3 & 2.3 & 3.4 \\
\hline Developing Asia & 2.3 & 2.7 & 4.2 & 3.8 & 4.1 & 5.4 & 7.8 \\
\hline Western Hemisphere & 8.8 & 10.6 & 6.7 & 6.3 & 5.2 & 5.3 & 7.8 \\
\hline
\end{tabular}

Source: International Financial Statistics (June 2009 CD).

Note: For inflation targeting (IT) countries, the year of adoption of IT is given in parenthesis (Source: Hammond (2009). 


\section{Output Growth}

Even as inflation was contained, growth witnessed acceleration, especially in the current decade (Chart 14). Real GDP growth averaged almost 9 per cent during the four year period 2004-08. Under the impact of the global financial crisis, growth moderated to 6.7 per cent in 2008-09 in contrast to outright contraction of activity in most economies.

Chart 14

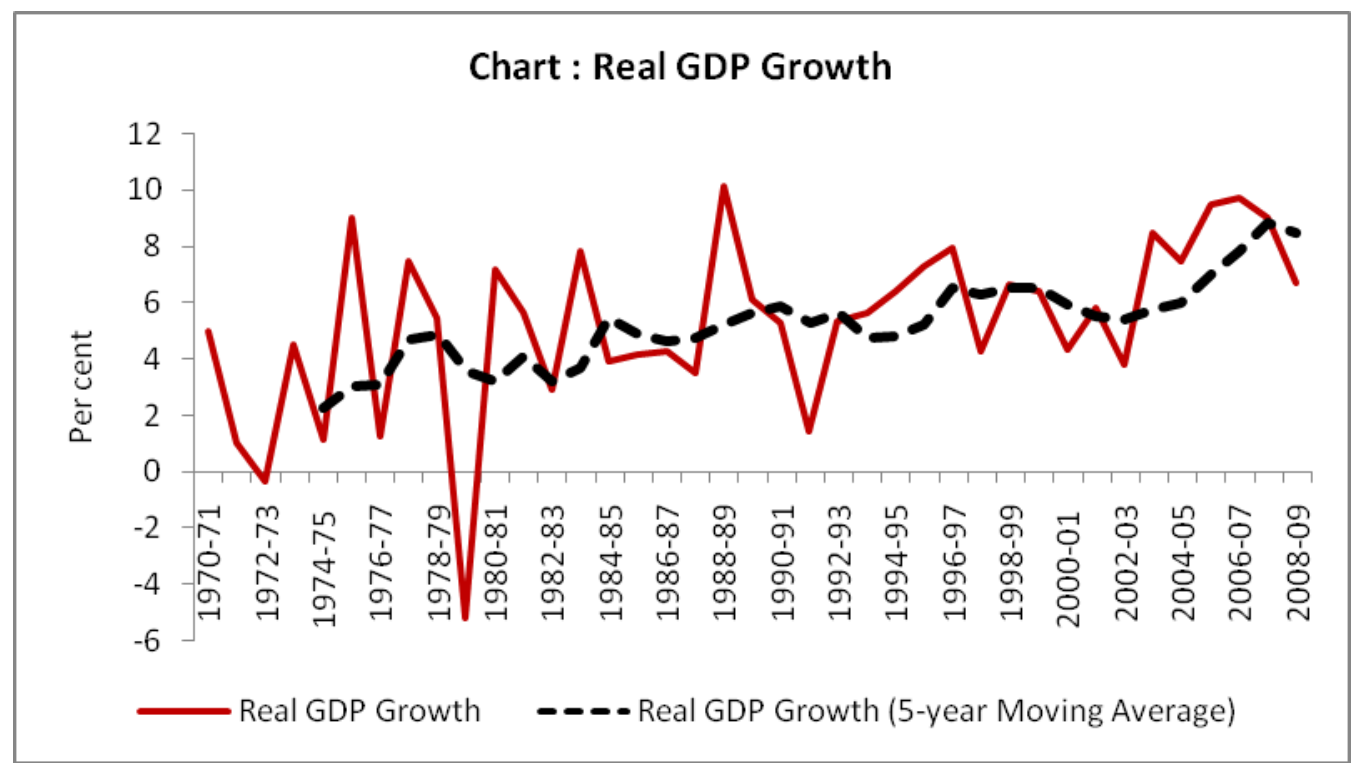

Amongst the major EMEs, India was the second fastest growing economy after China during 2002-09 (Table 21 and Chart 15) ${ }^{12}$. Along with China, India is one of the few countries that would record positive growth during 2009.

\footnotetext{
${ }^{12}$ While during 2002-07 (period taken in Chart 17) growth of Latvia was higher than India, the Latvian economy contracted by 5 per cent in 2008 and is projected to contract by another 12 per cent in 2009. Thus, during 2002-09, India's growth is higher than Latvia.
} 
Table 21: Real GDP Growth: Cross-Country Comparison

\begin{tabular}{|c|c|c|c|c|c|c|c|c|}
\hline \multirow[b]{2}{*}{ Country } & \multirow[b]{2}{*}{2002} & \multirow{2}{*}{2003} & \multirow{2}{*}{2004} & \multirow{2}{*}{2005} & \multirow{2}{*}{2006} & \multirow{2}{*}{2007} & \multicolumn{2}{|c|}{ (Per cent) } \\
\hline & & & & & & & 2008 & $2009 \mathrm{P}$ \\
\hline 1 & 2 & 3 & 4 & 5 & 6 & 7 & 8 & 9 \\
\hline \multicolumn{9}{|c|}{ Emerging Market Economies } \\
\hline Argentina & -10.9 & 8.8 & 9.0 & 9.2 & 8.5 & 8.7 & 7.0 & -1.5 \\
\hline Brazil (1999) & 2.7 & 1.1 & 5.7 & 3.2 & 4.0 & 5.7 & 5.1 & -1.3 \\
\hline Chile (1999) & 2.2 & 4.0 & 6.0 & 5.6 & 4.6 & 4.7 & 3.2 & 0.1 \\
\hline China,P.R.: Mainland & 9.1 & 10.0 & 10.1 & 10.4 & 11.6 & 13.0 & 9.0 & 7.5 \\
\hline Colombia (1999) & 2.5 & 4.6 & 4.7 & 5.7 & 6.9 & 7.5 & 2.5 & 0.0 \\
\hline Guatemala (1991) & 3.9 & 2.5 & 3.2 & 3.3 & 5.4 & 6.3 & 4.0 & 1.0 \\
\hline Hungary (2001) & 4.1 & 4.2 & 4.8 & 4.0 & 4.0 & 1.1 & 0.6 & -3.3 \\
\hline Iceland & 0.1 & 2.4 & 7.7 & 7.5 & 4.5 & 5.5 & 0.3 & -10.6 \\
\hline India & 4.6 & 6.9 & 7.9 & 9.2 & 9.8 & 9.3 & 7.3 & 5.4 \\
\hline Indonesia (2005) & 4.5 & 4.8 & 5.0 & 5.7 & 5.5 & 6.3 & 6.1 & 2.5 \\
\hline Latvia & 6.5 & 7.2 & 8.7 & 10.6 & 12.2 & 10.0 & -4.6 & -12.0 \\
\hline Malaysia & 5.4 & 5.8 & 6.8 & 5.3 & 5.8 & 6.3 & 4.6 & -3.5 \\
\hline Mexico (2001) & 0.8 & 1.7 & 4.0 & 3.2 & 5.1 & 3.3 & 1.3 & -7.3 \\
\hline Peru (2002) & 5.0 & 4.0 & 5.0 & 6.8 & 7.7 & 8.9 & 9.8 & 3.5 \\
\hline Philippines (2002) & 4.4 & 4.9 & 6.4 & 5.0 & 5.4 & 7.2 & 4.6 & 0.0 \\
\hline Poland (1998) & 1.4 & 3.9 & 5.3 & 3.6 & 6.2 & 6.7 & 4.8 & -0.7 \\
\hline Romania (2005) & 5.0 & 5.3 & 8.5 & 4.1 & 7.9 & 6.2 & 7.1 & -4.1 \\
\hline Russia & 4.7 & 7.3 & 7.2 & 6.4 & 7.7 & 8.1 & 5.6 & -6.5 \\
\hline South Africa (2000) & 3.7 & 3.1 & 4.9 & 5.0 & 5.3 & 5.1 & 3.1 & -0.3 \\
\hline Thailand (2000) & 5.3 & 7.1 & 6.3 & 4.6 & 5.2 & 4.9 & 2.6 & -3.0 \\
\hline Turkey (2006) & 6.2 & 5.3 & 9.4 & 8.4 & 6.9 & 4.7 & 1.1 & -5.1 \\
\hline \multicolumn{9}{|c|}{ Advanced Economies } \\
\hline Australia (1993) & 4.3 & 3.0 & 3.8 & 2.8 & 2.8 & 4.0 & 2.1 & -1.4 \\
\hline Canada (1991) & 2.9 & 1.9 & 3.1 & 2.9 & 3.1 & 2.7 & 0.5 & -2.3 \\
\hline China,P.R.:Hong Kong & 1.8 & 3.0 & 8.5 & 7.1 & 7.0 & 6.4 & 2.5 & -4.5 \\
\hline Czech Republic (1997) & 1.9 & 3.6 & 4.5 & 6.3 & 6.8 & 6.0 & 3.2 & -3.5 \\
\hline Euro area & 0.9 & 0.8 & 2.2 & 1.7 & 2.9 & 2.7 & 0.9 & -4.8 \\
\hline Israel (1997) & -0.6 & 1.8 & 5.0 & 5.1 & 5.2 & 5.4 & 3.9 & -1.7 \\
\hline Korea (1998) & 7.2 & 2.8 & 4.6 & 4.0 & 5.2 & 5.1 & 2.2 & -4.0 \\
\hline Japan & 0.3 & 1.4 & 2.7 & 1.9 & 2.0 & 2.4 & -0.6 & -6.0 \\
\hline New Zealand (1989) & 4.9 & 4.1 & 4.5 & 2.8 & 1.9 & 3.2 & 0.3 & -2.0 \\
\hline Switzerland & 0.4 & -0.2 & 2.5 & 2.5 & 3.4 & 3.3 & 1.6 & -3.0 \\
\hline United Kingdom (1992) & 2.1 & 2.8 & 2.8 & 2.1 & 2.8 & 3.0 & 0.7 & -4.2 \\
\hline United States & 1.6 & 2.5 & 3.6 & 2.9 & 2.8 & 2.0 & 1.1 & -2.6 \\
\hline
\end{tabular}

Source: World Economic Outlook (WEO) Database (April 2009) and WEO Update (July 2009), IMF. Note:

1. Data for 2009 are IMF projections.

2. For inflation targeting (IT) countries, the year of adoption of IT is given in parenthesis (Source: Hammond (2009). 


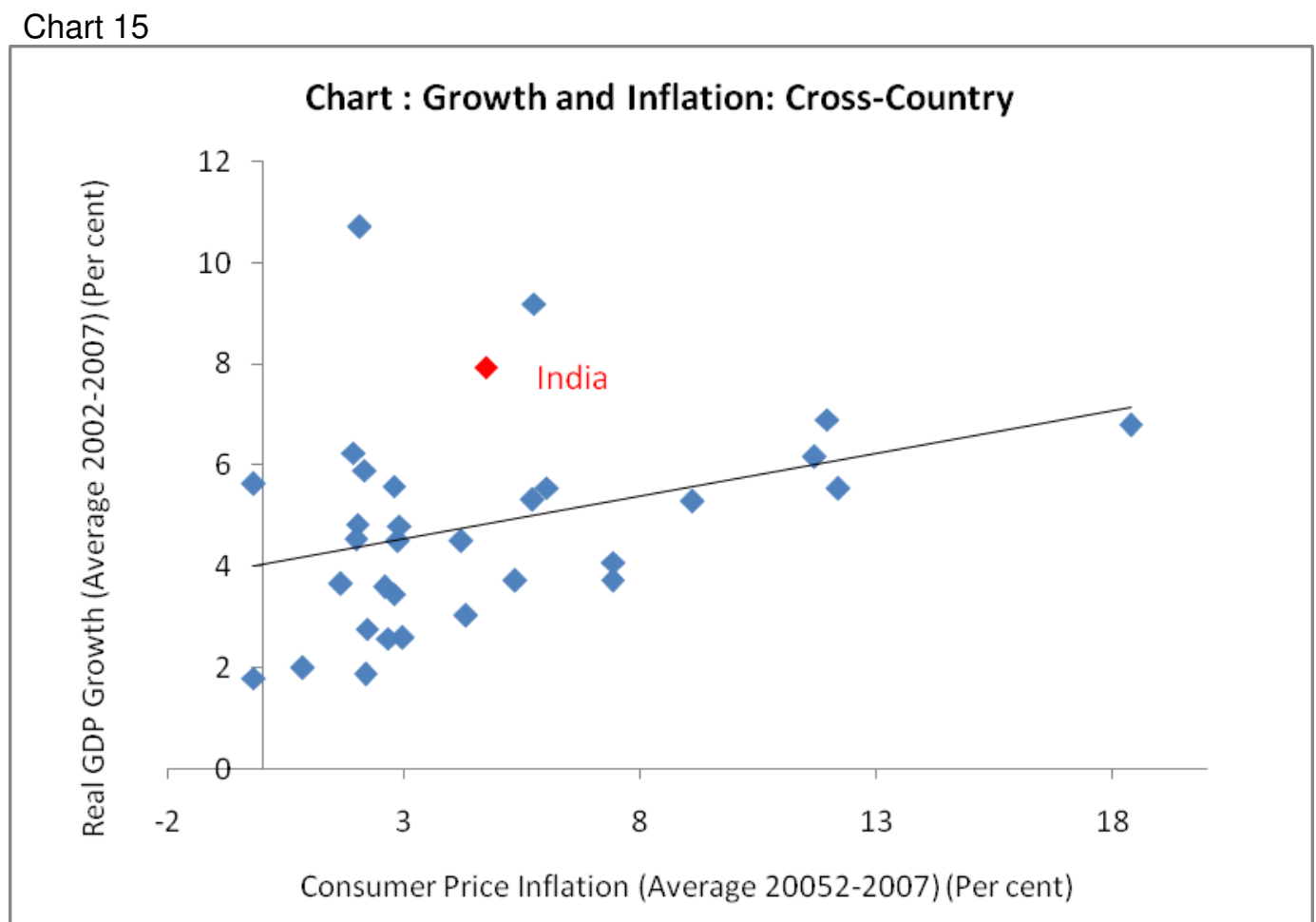

Thus, Indian growth since the early 1990 s has been quite creditable. It has been achieved in an environment of financial stability. Despite this record of high growth, low inflation, rapid credit expansion, substantial external opening and financial deepening while maintaining financial stability, an influential body of opinion has forcefully argued for a faster pace of liberalisation in both the domestic financial and external sectors. It is important to recognise that a banking crisis has output losses not only in the short-run, but these losses are persistent and, in many cases, such losses are not recouped even in the medium-to-long term. Thus, even if the growth rate returns to its pre-crisis rate - which is not necessarily the case - the level of output may remain well below its pre-crisis level. IMF (2009c) has attempted to quantify the impact of banking crises on output 
in the medium term. The key findings of the IMF study ${ }^{13}$ are: first, following a banking crisis, the path of output tends to be depressed substantially and persistently, with no rebound on average to the pre-crisis trend over the medium-term. Second, on average, in the sample events, output is found to fall steadily below its pre-crisis trend until the third year after the crisis. Third, seven years after the crisis, output in these episodes was 10 per cent below the trend on average. The output losses in specific cases can be very high - for instance, per capita output in Thailand seven years after the East Asian crisis is estimated to be only 44 per cent of the level had it continued to grow at its pre-crisis trend (Annex 6). Finally, the depressed output path tends to result from long-lasting reductions of roughly equal proportion in the employment rate, the capital-to-labour ratio, and total factor productivity. If so, the potential output growth rate of the economy also suffers. Against this backdrop, Indian growth acceleration, while ensuring financial stability, stands out and is reflective of the adroit macroeconomic and monetary management and a cautious approach to financial globalisation.

\section{Monetary Policy Independence}

It is usually argued that if a central bank attempts to manage the impossible trinity, monetary policy may not be independent. What has been the Indian experience in this regard? In a globalised economy, business cycles are getting increasingly synchronised. To that extent, monetary policy actions also seem to be synchronised. However, while India's external openness has increased significantly since the early

\footnotetext{
${ }^{13}$ The IMF study is based on financial crisis events from the early 1970s to 2002. The sample includes 88 banking crises and 222 currency crises, distributed across high-, middle-, and lowincome economies.
} 
1990s, domestic demand remains the key driver of economic activity. Thus, the size of output gaps need not be same across countries. Accordingly, inflation dynamics also differ across countries. These developments came to the forefront during the second half of 2007-08 and the first half of 2008-09. Following the sub-prime crisis, monetary policy in the US was loosened from August 2007 onwards. In India, at the same time, aggregate demand was seen as running ahead of supply; inflation pressures were rising on the back of demand as well as supply shocks. In contrast to the trends in the US, monetary policy continued to be in tightening mode in India (Chart 16).

Chart 16

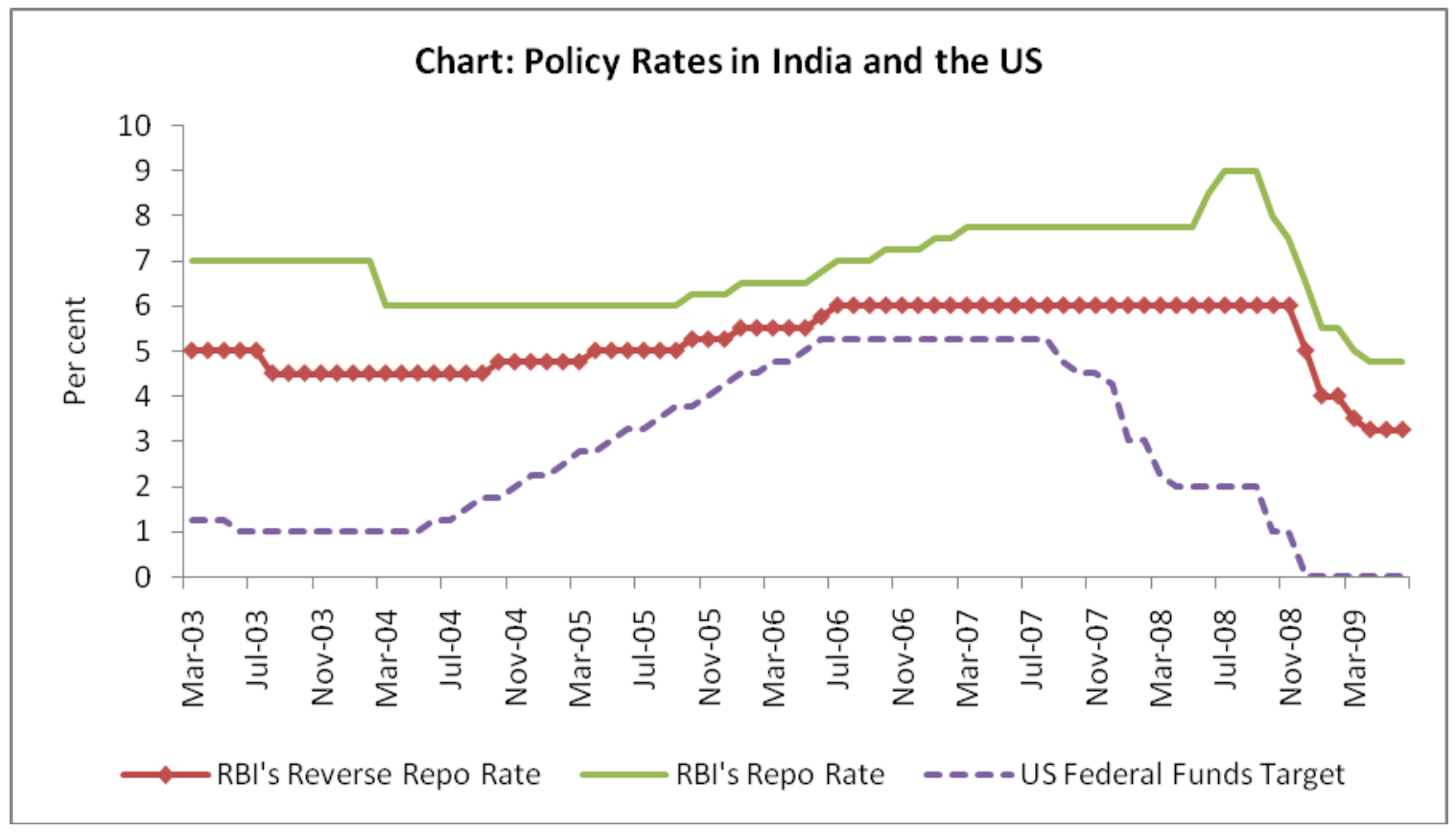

Following the failure of Lehman Brothers in September 2008, there was, however, sudden and severe weakening of the global economy. External demand witnessed a large collapse. There was also a substantial reversal in portfolio capital inflows and trade financing dried. Monetary policy, therefore, quickly reversed gear in the second half of 2008-09 and shifted into an accommodative mode. Liquidity was injected through cuts 
in cash reserve ratio and buyback/redemption of MSS securities as well as through some ad hoc measures. Thus, monetary policy actions have been largely driven by domestic macroeconomic and monetary conditions.

To summarise, "impossible trinity' was managed successfully in India despite massive capital inflows and volatility in such capital flows. Growth in monetary and credit aggregates was broadly in line with demands of the real economy. Inflation exhibited significant reduction from its levels prevailing during 1970s to mid-1990s, while real GDP growth recorded noticeable acceleration. These positive outcomes were made possible by using a variety of tools - policy preference for non-debt flows, active management of debt flows in the capital account, interventions in the foreign exchange market, sterilisation through multiple instruments, adequate reserves, continuous development of financial markets and the financial sector and use of prudential instruments. Such an integrated approach was, in turn, possible due to monetary policy which eschewed the narrow price stability/inflation targeting framework. Monetary policy was conducted with a view to ensuring not only price stability but also financial stability. In this endeavour, the fact that regulation of banks and key financial markets remains with the Reserve Bank permitted the Reserve Bank to use prudential instruments in addition to monetary instruments. More generally, policymakers also recognised that while financial markets, both domestic and global, provide useful signals, this is not always so. Financial markets are prone to herding and bubbles, which require pre-emptive policy measures to ensure price and financial stability. 


\section{CONCLUDING OBSERVATIONS}

There is now a growing consensus that a fully open capital account does not lead to higher growth. Rather, it increases vulnerabilities to financial crisis. As the current global financial crisis has shown, this is as true for EMEs as for advanced economies. Accordingly, capital account opening needs to be well-sequenced contingent upon developments in both the real sector and financial sector, and in fiscal policy. Greater caution is needed in liberalisation of debt flows. Among various resident entities, a more prudent regime for external borrowings is necessary for the banking sector and other financial intermediaries. Non-resident investments in risk-free sovereign debt instruments also need to be restricted since interest rate differentials favour EMEs and these differentials can encourage hot money.

In recent years, many EMEs have received capital flows much larger than their financing requirements. When capital flows are significantly in excess of a sustainable level of current account deficit, and the exchange rate is flexible, it is obvious that they cannot be absorbed domestically, howsoever efficient the financial system may be. Real exchange rate misalignment, current account imbalances, excesses in credit markets, asset price booms, overheating and inflation are the most likely outcomes. It would be question of time before financial fragility leads to crisis. Thus, surging capital flows should not be perceived as a sign of strength, but as a potential source of disequilibrium (UNCTAD, 2009). Capital flows, therefore, need to be managed actively. Capital controls can be effective, even though they may not be foolproof, and are in fact subject to leakage in the context of the current global financial market environment. Capital controls have to be a part of an overall package comprising exchange rate flexibility, the maintenance of adequate reserves, sterilisation and development of the financial sector. There is clearly need for the 
deployment of multiple instruments. The current fashion of single objective, single instrument monetary policy is undoubtedly inadequate to deal with capital flows.

Against this backdrop, the Indian experience holds important lessons. Monetary policy in India has faced growing challenges from large and volatile capital flows since 1993-94, especially during 2007-09. In response to these capital flows, a multi-pronged approach was adopted. Key elements of this framework have been: active management of the capital account, especially debt flows; tighter prudential restrictions on access of financial intermediaries to external borrowings; flexibility in exchange rate movements but with capacity to intervene in times of excessive volatility; treating capital flows as largely volatile unless proven otherwise; building up of adequate reserves; sterilisation of interventions in the foreign exchange market through multiple instruments, including cash reserve requirements; continuous development of financial markets in terms of participants and instruments, but with a cautious approach to risky instruments; strengthening of the financial sector through prudential regulation while also enhancing competition; pre-emptive tightening of prudential norms; and refinements in institutional framework for monetary policy. Policies operate symmetrically. During periods of heavy inflows, liquidity is absorbed through increases in the cash reserve ratio and issuances under the market stabilisation scheme. During periods of reversal, liquidity is injected through cuts in cash reserve ratio and unwinding of the market stabilisation scheme. Overall, rather than relying on a single instrument, many instruments have been used in coordination. This was enabled by the fact that both monetary policy and regulation of banks and other financial institutions and key financial markets are under the jurisdiction of the Reserve Bank, which permitted smooth use of various policy instruments. Unlike many EMEs, India has been running 
trade and current account deficits. While the current account deficit is modest and manageable, the trade deficit is high. Management of the capital account and exchange rate is also important from this perspective.

The outcomes have been satisfactory. Growth in monetary and credit aggregates was, by and large, contained within desired trajectories and consistent with the overall GDP growth objective. There has been significant financial deepening. Inflation has been reduced significantly from its levels prevailing during the forty year period until the late 1990s. Growth has witnessed significant acceleration on the back of productivity gains, which are also reflected in the growth of exports of goods and services. Domestic investment has increased substantially since the beginning of this decade and this is predominantly financed by domestic savings. The surge in investment and savings was made possible by efficient allocation of resources by the domestic banking system and financial markets, despite many constraints. Overall, financial stability has been maintained.

Capital flows volatility poses large challenges but these can be managed. Key lessons from the Indian experience are that monetary policy needs to move away from narrow price stability/inflation targeting objective. Central banks need to be concerned not only with monetary policy but also with development and regulation of banks and key financial markets -money, credit, bond and currency markets. Depending on the institutional legacy within different countries, if these additional functions are not vested within the central bank, adequate coordination mechanisms need to be put in place to enable the central bank to interact with the other agencies and act on needed prudential measures. Given the volatility and the need to ensure broader stability of the financial system, central banks need multiple instruments. Capital account management has to be countercyclical, just as is the case monetary and fiscal policies. 
Judgements in capital account management are no more complex than those made in monetary management.

Looking ahead, as the Indian economy recovers from the drag imposed by the global financial crisis and returns to its pre-crisis growth trajectory of 9 per cent or above, the current cautious approach towards capital account liberalisation, continuous development of financial markets and further strengthening of the financial sector will need to continue. However, the return to the high growth path would also be contingent upon progress in a number of other areas: strengthening of agriculture, improvement in physical, social and urban infrastructure; and reversing the deterioration in public finances. 


\section{References}

Aghion, Philippe, Philippe Bacchetta, Romain Ranciere and Kenneth Rogoff, 2009, "Exchange Rate Volatility and Productivity Growth: The Role of Financial Development", Journal of Monetary Economics, 56, pages 494-513.

Asian Development Bank (2009), Asian Development Outlook 2009.

Cecchetti, Stephen, Marion Kohler and Christian Upper, 2009, "Financial Crisis and Economic Activity", Paper Presented at Federal Reserve Bank of Kansas City's Symposium at Jackson Hole.

Chinn, Menzie and Hiro Ito, 2008, "A New Measure of Financial Openness", Journal of Comparative Policy Analysis, Vol. 10, Issue 3 September, pp. 309 - 322.

Committee on the Global Financial System, 2009, Report of the Working Group on Capital flows to Emerging Market Economies (Chairman: Rakesh Mohan), Bank for International Settlements, Basel.

Goodhart, Charles, 2009, "Liquidity Management", Remarks at Federal Reserve Bank of Kansas City's Symposium at Jackson Hole.

Gordon, James and Poonam Gupta, 2004, "Nonresident Deposits in India: In Search of Return?", Working Paper WP/049/48, International Monetary Fund.

Government of India, 2007, Report of the High Powered Expert Committee on Making Mumbai an International Financial Centre (Chairman: Percy Mistry), New Delhi: Sage India, 2007

Government of India, 2008, Report of the Committee on Financial Sector Reforms (Chairman: Raghuram Rajan), New Delhi:

Grenville, Stephen, 2008, "Central Banks and Capital Flows", Discussion Paper 87, Asian Development Bank Institute.

Hammond, Gill, 2009, "State of the Art of Inflation Targeting", Handbook No. 29, Centre for Central Banking Studies, Bank of England.

International Monetary Fund, 2009a, "India: Staff Report for the 2008 Article IV Consultation", January.

---- ,2009b, World Economic Outlook Database, April. 
---- (2009c) "What's the Damage? Medium-term Output Dynamics After Financial Crises", World Economic Outlook (Chapter 4), October 2009.

Krugman, Paul, 2009, "How did Economists Get it so Wrong?", The New York Times, September 6, 2009.

Mohan, Rakesh, 2004, "Challenges to Monetary Policy in a Globalising Context", Reserve Bank of India Bulletin, January [Published in Mohan, Rakesh (2009), "Monetary Policy in a Globalised World: A Practitioner's View", Oxford University Press, New Delhi].

--- , 2007a, "Capital Account Liberalisation and Conduct of Monetary Policy: The Indian Experience", Reserve Bank of India Bulletin, July.

--- , 2007b, "India's Financial Sector Reforms: Fostering Growth While Containing Risk", Reserve Bank of India Bulletin, December.

--- , 2008a, "Capital Flows to India", Reserve Bank of India Bulletin, December.

---- 2008b, "The Growth Record of the Indian Economy 1950-2008 : A Story of Sustained Savings and Investment", Reserve Bank of India Bulletin, March.

----, 2008c, "The Role of Fiscal and Monetary Policies in Sustaining Growth With Stability in India", Asian Economic Policy Review, Vol. 3, pages 209-236

--- , 2009a, "Monetary Policy in a Globalised World: A Practitioner's View", Oxford University Press, New Delhi.

--- ,2009b, "Global Financial Crisis: Causes, Impact, Policy Responses and Lessons", Reserve Bank of India Bulletin, May

--- ,2009c, "Emerging Contours of Financial Regulation: Challenges and Dynamics", Financial Stability Review, September 2009, Banque de France, pp.103-116.

Mohan, Rakesh and Muneesh Kapur, 2009, Capital Account Liberalisation and Regulation: Lessons for Emerging Market Economies, Working Paper, Asian Development Bank Institute (forthcoming).

Obstfeld, Maurice, 2009, "International Finance and Growth in Developing Countries: What Have We Learned?", Staff Papers 56(1), International Monetary Fund.

Reddy, Y.V., 2008, "Management of the Capital Account in India: Some Perspectives", Reserve Bank of India Bulletin, February. 
-----, 2009, "India and the Global Financial Crisis: Managing Money and Finance", Orient BlackSwan, New Delhi.

Reinhart, Carmen M. and Kenneth S. Rogoff, 2008, "This Time is Different: A Panoramic View of Eight Centuries of Financial Crises", Working Paper 13882, National Bureau of Economic Research.

Reserve Bank of India, 2008, Report on Currency and Finance 2006-08.

Seelig, Steven and Alicia Novoa (2009), "Governance Practices at Financial Regulatory and Supervisory Agencies", Working Paper WP/09/135, July, International Monetary Fund.

Shah, Ajay and Ila Patnaik, 2008, "Managing Capital Flows: The Case of India", Discussion Paper 98, Asian Development Bank Institute.

Shirakawa, Masaaki, 2009, "International Policy Response to Financial Crisis", Remarks at Federal Reserve Bank of Kansas City's Symposium at Jackson Hole.

Singh, Bhupal, 2007, "Corporate Choice for Overseas Borrowings: The Indian Evidence", Reserve Bank of India Occasional Papers, Vol.28, No.3, Winter, pp.1-33.

Stiglitz, Joseph E., 2003, "Globalization and Its Discontents", Norton: New York.

Subbarao, D., 2009, "Global Financial Crisis: Questioning the Questions", Reserve Bank of India Bulletin, July.

-----“Financial Stability: Issues and Challenges", Reserve Bank of India Bulletin, October.

Taylor, John, 2008, "The Impacts of Globalisation on Monetary Policy" in "International Symposium: Globalisation, Inflation and Monetary Policy", Banque de France, March.

Thorat, Usha, 2009, "Global Agenda for Regulatory and Supervisory Reforms: The Stock Taking and Way Forward", Reserve Bank of India Bulletin, October. 
Turner Review (2009), The Turner Review: A Regulatory Response to the Global Banking Crisis, by Lord Turner, Chairman, Financial Services Authority, UK.

United Nations Conference on Trade and Development, 2009, "Trade and Development Report, 2009", United Nations. 
Annex 1

\section{Exchange Rates and Current Account Balance: Cross-Country Analysis}

According to Taylor (2008), in the state of the art monetary models, an increase in the trade deficit will tend to lead to a depreciation of the currency. Is this assumption supported by data?

In order to examine this assumption, an analysis of current account balance and exchange rate (both nominal and real) is attempted for the recent period 2002 to 2007 (i.e., for the period prior the crisis). The analysis is attempted for a sample of 36 countries (including the euro area $)^{14}$. The variables are defined as follows. Current account balance is taken as per cent to GDP, averaged for the period 2002-2007. As regards exchange rate, variation between December 2001 and December 2007 is considered for nominal effective exchange rate and real effective exchange rate.

The analysis shows a negative relationship, i.e., current account deficits are associated with not only real appreciation but even nominal appreciation (Annex Chart 1). As many as 14 out of 36 sample countries had current account deficits but still experienced real appreciation; another 9 countries recorded real depreciation despite current account surpluses. In regressions of variations in nominal and real effective exchange rates on current account balance (per cent to GDP), the coefficients are significant (Annex Table 1).Thus, at least in the current decade, countries with large current account deficits have surprisingly experienced a

\footnotetext{
${ }^{14}$ The countries included are: Argentina, Australia, Brazil, Canada, Chile, China, Taiwan, Croatia, Czech Republic, Euro area, Hong Kong, Hungary, Iceland, India, Indonesia, Israel, Japan, Korea, Latvia, Lithuania, Malaysia, Mexico, New Zealand, Peru, Philippines, Poland, Romania, Russia, Slovakia, Slovenia, South Africa, Switzerland, Thailand, Turkey, United Kingdom and United States.
} 
tendency for their exchange rates to appreciate, which can have significant deleterious effects on their real economies.

\section{Annex Chart 1: Current Account Balance and Exchange Rate}
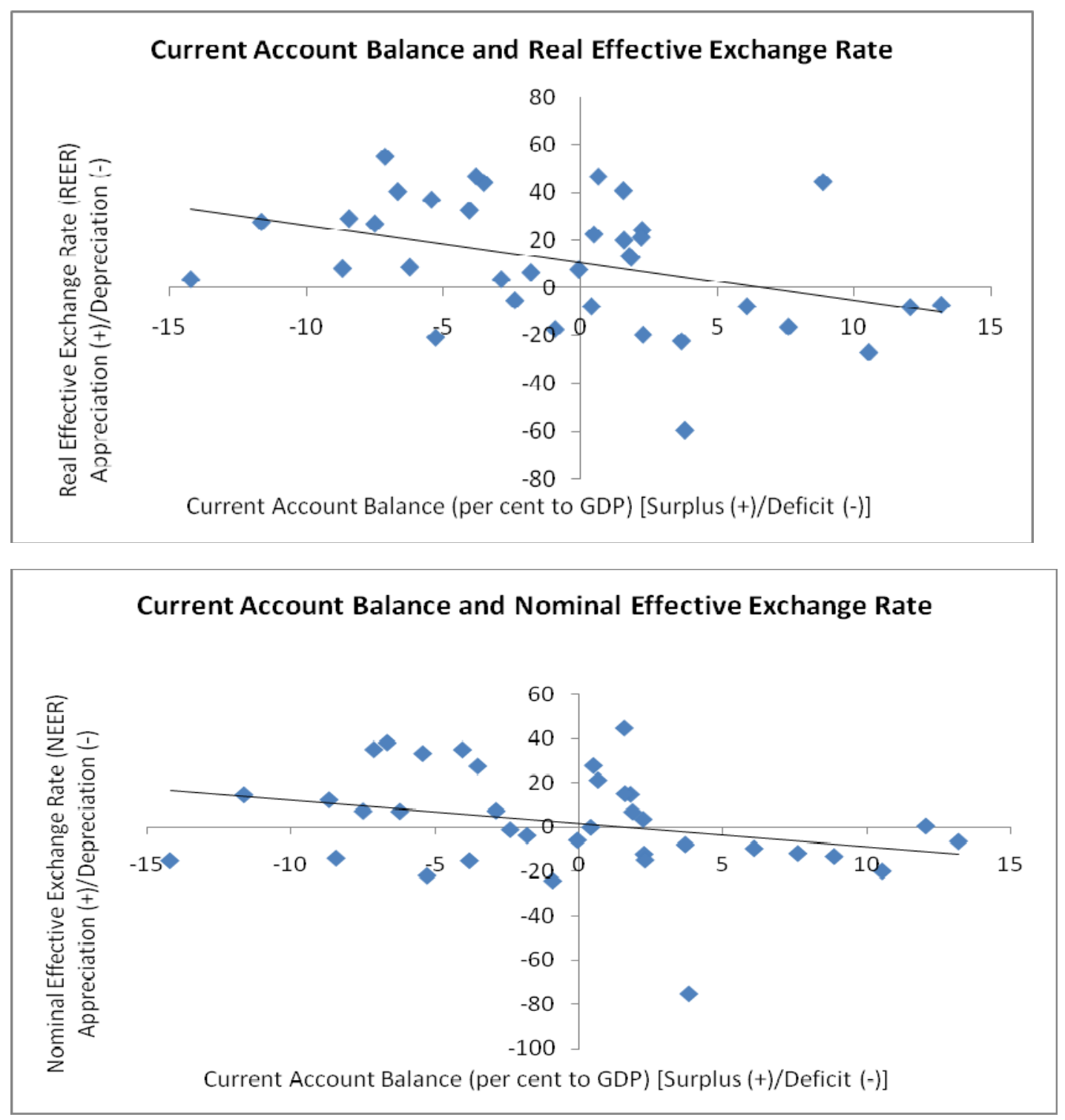

Note: See notes to Annex Table 1 for variable definitions, country coverage and sources. 


\section{Annex Table 1: Current Account Balance and Exchange Rate: Cross-Country Results}

$$
\begin{array}{rlr}
\text { NEER }= & 1.7-1.04 \text { CAB } & \text { R-bar^2 }=0.06 \\
& (0.5) \quad(1.8) & \\
\text { REER }= & 10.4-1.57 \text { CAB } & \text { R-bar^2 }=0.12 \\
& (2.5) \quad(2.4)
\end{array}
$$

Note:

Figures in parentheses are t-statistics.

NEER = variation in nominal effective exchange rate between December 2007 and December 2001

REER = variation in real effective exchange rate between December 2007 and December 2001

CAB = Current account balance (per cent to GDP) (average for 2002-2007)

NEER and REER data are from Bank for International Settlements and CAB from World Economic Outlook Database (April 2009), IMF.

The analysis is conducted for 36 countries. See footnote 14 for the list of countries. 


\section{Determinants of Non-Resident Deposit Inflows}

Following the extant literature (for instance, Gordon and Gupta, 2004), inflows under NRI deposits schemes are postulated to depend upon relative interest rates on these deposit schemes ${ }^{15}$, exchange rate of the rupee, and economic conditions in the source countries (which are proxied by world exports). Since the factors impacting the rupee and foreign currency denominated deposits can be different, inflows under the two deposits schemes - NRERA and FCNRB - are modelled separately. Exchange rate movements can be expected to be amongst the determinants of rupee denominated deposits (NRERA) where the exchange rate risk is borne by the depositor. As regards foreign currency denominated deposits (FCNRB), depositors do not bear any exchange rate risk and the exchange rate, a priori, need not be a determinant of such deposits. Dummy is included to capture flows into these deposits from the bullet redemption of India Millennium Deposits (IMDs) in December 2005. Another dummy is included to capture the impact of the collapse of Lehman Brothers.

The estimated equations for NRERA and FCNRB deposits are set out in Annex Table 2. All the variables are significant and have the expected signs.

Estimates suggest that, over the sample period, an increase of 100 basis points in interest rates on NRERA deposits is associated with an increase of US \$114 million in inflows under these deposits with a lag of one month; the long-run impact is higher at US \$ 146 million. For FCNRB deposits, the corresponding short- and long-run impact is estimated at US

\footnotetext{
${ }^{15}$ Since interest rate ceilings on spreads are specified with respect to LIBOR/swap rates, these spreads can be interpreted as relative interest rates (relative to interest rates in foreign countries).
} 
\$213 million and US \$ 270 million, respectively. The combined impact of an increase of 100 basis points in interest rate ceilings on both the schemes is, therefore, estimated to be an increase of around US $\$ 350$ million per month in these deposits in the short-run and around US \$ 415 million in the long-run. The annual impact is, therefore, estimated to be US \$ 4.2-5.0 billion.

Amongst other determinants, an increase of US $\$ 1$ billion in world exports (a proxy for economic conditions in the source countries and, in turn, that of income of non-residents) leads to an increase of US $\$ 142$ million and US \$87 million, respectively, per month in inflows under NRERA and FCNRB deposits in the short-run. The long-run impact is around US $\$ 182$ billion and US $\$ 110$ billion, respectively.

Exchange rate movements are not found to have impact on FCNRB deposits, as expected. However, in the case of NRERA deposits, a depreciation of Rs. 1 (per US dollar) is followed by an outflow of around US $\$ 50$ million.

Redemption of IMDs had a positive one-time impact on FCNRB deposits, since both the deposits are in foreign currency. However, IMD redemption did not have any impact on the rupee deposits.

Finally, the collapse of Lehman Brothers had a huge negative impact on FCNRB inflows, but surprisingly, a positive impact on NRERA deposits. The negative impact on FCNRB deposits is almost offset by higher inflows under NRERA deposits. 
Annex Table 2: Determinants of Non-Resident Deposit Inflows

\begin{tabular}{|c|c|c|c|c|}
\hline \multirow{4}{*}{$\begin{array}{l}\text { Explanatory } \\
\text { Variables }\end{array}$} & $\begin{array}{l}\text { Non-Residen } \\
\text { Rupee } \\
\text { (NRERA) }\end{array}$ & $\begin{array}{r}\text { External } \\
\text { Accounts }\end{array}$ & \multicolumn{2}{|c|}{$\begin{array}{l}\text { Foreign Currency Non- } \\
\text { Resident Bank (FCNRB) }\end{array}$} \\
\hline & $\begin{array}{l}\text { Sample Perioc } \\
\text { August } \\
2009\end{array}$ & 3_-February & \multicolumn{2}{|c|}{$\begin{array}{l}\text { Sample Period: } \\
\text { May 2001-February } 2009\end{array}$} \\
\hline & \multicolumn{2}{|c|}{$\begin{array}{l}\text { Dependent Variable: } \\
\text { NRERA }\end{array}$} & \multicolumn{2}{|c|}{$\begin{array}{l}\text { Dependent Variable: } \\
\text { FCNRB }\end{array}$} \\
\hline & Coefficient & t-statistic & Coefficient & t-statistic \\
\hline Constant & -0.8 & 0.0 & 81.1 & 4.6 \\
\hline NREINT $\{1\}$ & 1.15 & 2.2 & & \\
\hline FCNRINT $\{1\}$ & & & 2.13 & 4.2 \\
\hline DWEXP & 1.42 & 3.0 & 0.87 & 3.2 \\
\hline NRERA $\{4\}$ & 0.22 & 2.3 & & \\
\hline FCNRB $\{2\}$ & & & 0.21 & 4.0 \\
\hline DINR $\{3\}$ & -51.1 & 1.7 & & \\
\hline DUMIMD & & & 759.5 & 37.8 \\
\hline DUMLEH & 662.9 & 15.3 & -710.6 & 22.6 \\
\hline R-bar ${ }^{2}$ & 0.30 & & 0.52 & \\
\hline Durbin's h & 1.56 & & 0.71 & \\
\hline
\end{tabular}

\section{Note:}

Equations have been estimated using monthly data. Variables are as following:

NRERA = monthly inflows/outflows (net) under Non-Resident External Rupee Accounts scheme (measured in US \$ million)

$\mathrm{FCNRB}=$ monthly inflows/outflows (net) under Foreign Currency Non-Resident Bank (FCNRB) Deposits scheme (measured in US \$ million)

NREINT = interest rate ceiling spread (basis points) over LIBOR for deposits under NonResident External Rupee Accounts scheme

FCNRINT = interest rate ceiling spread (basis points) over LIBOR for deposits under Foreign Currency Non-Resident Bank (FCNRB) Deposits scheme

DINR = month-on-month variation in exchange rate of Rupee vis-a-vis US dollar.

DWEXP = month-on-month variation in world exports (measured in US \$ billion) (Source: IFS, IMF)

DUMIMD = dummy for redemption of India Millennium Deposits (IMDs) deposits in December 2005 (December 2005=1; 0 otherwise)

DUMLEH = dummy for Lehman Brothers failure (October 2008=1; 0 otherwise) 


\section{Chinn-Ito Indices of Financial Openness}

Annex 3

\begin{tabular}{|c|c|c|c|c|c|c|c|c|c|c|}
\hline Year & India & Indonesia & Korea & Malaysia & Philippines & Thailand & Argentina & Brazil & US & UK \\
\hline 1 & 2 & 3 & 4 & 5 & 6 & 7 & 8 & 9 & 10 & 11 \\
\hline 1970 & -1.13 & 0.45 & -1.13 & -0.09 & -0.32 & -0.09 & 0.72 & -1.81 & 2.53 & -1.81 \\
\hline 1971 & -1.13 & 0.72 & -1.13 & -0.09 & -0.59 & -0.09 & -1.00 & -1.81 & 2.53 & -0.77 \\
\hline 1972 & -1.13 & 0.99 & -1.13 & -0.09 & -0.86 & -0.09 & -1.27 & -1.81 & 2.53 & -0.77 \\
\hline 1973 & -1.13 & 1.26 & -1.13 & 0.18 & -1.13 & -0.09 & -1.54 & -1.81 & 2.53 & -0.77 \\
\hline 1974 & -1.13 & 1.26 & -1.13 & 0.45 & -1.13 & -0.09 & -1.81 & -1.81 & 2.53 & -0.77 \\
\hline 1975 & -1.13 & 1.26 & -1.13 & 0.72 & -1.13 & -0.09 & -1.81 & -1.81 & 2.53 & -0.77 \\
\hline 1976 & -1.13 & 1.26 & -1.13 & 0.99 & -1.13 & -0.09 & -1.81 & -1.81 & 2.53 & -0.77 \\
\hline 1977 & -1.13 & 0.22 & -1.13 & 1.26 & -1.13 & -0.09 & -0.09 & -1.81 & 2.53 & -0.77 \\
\hline 1978 & -1.13 & 1.26 & -0.09 & 1.26 & -1.13 & -0.09 & -0.09 & -1.81 & 2.53 & -0.77 \\
\hline 1979 & -1.13 & 1.26 & -0.09 & 1.26 & -1.13 & -0.09 & -0.09 & -1.81 & 2.53 & 1.45 \\
\hline 1980 & -1.13 & 1.26 & -0.09 & 1.26 & -1.13 & -0.09 & -0.09 & -1.81 & 2.53 & 1.72 \\
\hline 1981 & -1.13 & 1.26 & -0.09 & 1.26 & -1.13 & -0.09 & -0.09 & -1.81 & 2.53 & 1.99 \\
\hline 1982 & -1.13 & 2.53 & -1.13 & 2.53 & -1.13 & -0.09 & -1.13 & -1.81 & 2.53 & 2.26 \\
\hline 1983 & -1.13 & 2.53 & -1.13 & 2.53 & -1.13 & -0.09 & -1.13 & -1.81 & 2.53 & 2.53 \\
\hline 1984 & -1.13 & 2.53 & -1.13 & 2.53 & -1.13 & -0.09 & -1.13 & -1.81 & 2.53 & 2.53 \\
\hline 1985 & -1.13 & 2.53 & -1.13 & 2.53 & -0.09 & -0.09 & -1.13 & -1.81 & 2.53 & 2.53 \\
\hline 1986 & -1.13 & 2.53 & -1.13 & 2.53 & -1.13 & -0.09 & -1.13 & -1.81 & 2.53 & 2.53 \\
\hline 1987 & -1.13 & 2.53 & -1.13 & 2.53 & -1.13 & -0.09 & -1.13 & -1.81 & 2.53 & 2.53 \\
\hline 1988 & -1.13 & 2.53 & -0.09 & 2.53 & -1.13 & -0.09 & -1.13 & -1.81 & 2.53 & 2.53 \\
\hline 1989 & -1.13 & 2.53 & -0.09 & 2.53 & -1.13 & -0.09 & -1.13 & -1.81 & 2.53 & 2.53 \\
\hline 1990 & -1.13 & 2.53 & -0.09 & 2.53 & -1.13 & -0.09 & -1.13 & -1.81 & 2.53 & 2.53 \\
\hline 1991 & -1.13 & 2.53 & -0.09 & 2.53 & -1.13 & -0.09 & -1.13 & -1.81 & 2.53 & 2.53 \\
\hline 1992 & -1.13 & 2.53 & -0.09 & 2.53 & 0.14 & -0.09 & -1.13 & -1.81 & 2.53 & 2.53 \\
\hline 1993 & -1.13 & 2.53 & -0.09 & 1.26 & 0.14 & -0.09 & 1.45 & -1.81 & 2.53 & 2.53 \\
\hline 1994 & -1.13 & 2.53 & -0.09 & 1.26 & 0.14 & -0.09 & 1.72 & -1.81 & 2.53 & 2.53 \\
\hline 1995 & -1.13 & 2.53 & -0.09 & 1.26 & 1.18 & -0.09 & 1.99 & -1.81 & 2.53 & 2.53 \\
\hline 1996 & -1.13 & 2.26 & -1.13 & 0.99 & 0.14 & -0.09 & 1.22 & -1.81 & 2.53 & 2.53 \\
\hline 1997 & -1.13 & 1.99 & -1.13 & 0.72 & 0.14 & -0.09 & 2.53 & -1.81 & 2.53 & 2.53 \\
\hline 1998 & -1.13 & 1.04 & -1.13 & 0.45 & 0.14 & -0.09 & 2.26 & -1.13 & 2.53 & 2.53 \\
\hline 1999 & -1.13 & 1.45 & -1.13 & 0.18 & 0.14 & -0.09 & 1.99 & -1.13 & 2.53 & 2.53 \\
\hline 2000 & -0.09 & 1.18 & -1.13 & -0.09 & 0.14 & -0.09 & 1.72 & -1.13 & 2.53 & 2.53 \\
\hline 2001 & -1.13 & 1.18 & -0.09 & -0.09 & 0.14 & -0.09 & -0.86 & -1.13 & 2.53 & 2.53 \\
\hline 2002 & -1.13 & 1.18 & -0.09 & -0.09 & 0.14 & -0.09 & -1.13 & 0.18 & 2.53 & 2.53 \\
\hline 2003 & -1.13 & 1.18 & -0.09 & -0.09 & 0.14 & -0.09 & -0.09 & 0.45 & 2.53 & 2.53 \\
\hline 2004 & -1.13 & 1.18 & -0.09 & -0.09 & 0.14 & -0.09 & -0.09 & 0.72 & 2.53 & 2.53 \\
\hline 2005 & -1.13 & 1.18 & -0.09 & -0.09 & 0.14 & -0.09 & -0.09 & 0.99 & 2.53 & 2.53 \\
\hline 2006 & -1.13 & 1.18 & -0.09 & -0.09 & 0.14 & -0.09 & -0.77 & 1.26 & 2.53 & 2.53 \\
\hline 2007 & -1.13 & 1.18 & 0.18 & -0.09 & 0.14 & -1.13 & -0.77 & 0.99 & 2.53 & 2.53 \\
\hline
\end{tabular}

Source: Hiro Ito's website http:/web.pdx.edu/ ito 
Annex 4

Capital Flows (net): Country-wise

\begin{tabular}{|c|c|c|c|c|c|}
\hline \\
\hline Country & $1990-96$ & $1997-2002$ & $2003-06$ & 2007 & 2008 \\
\hline 1 & 2 & 3 & 4 & 5 & 6 \\
\hline United States & 87 & 318 & 639 & 664 & 510 \\
\hline Spain & 11 & 6 & 56 & 139 & 142 \\
\hline India & 7 & 10 & 25 & 98 & 40 \\
\hline Russia & -19 & -10 & 0 & 96 & -136 \\
\hline Brazil & 11 & 16 & 6 & 88 & 28 \\
\hline China,P.R.: Mainland & 21 & 15 & 56 & 70 & 16 \\
\hline United Kingdom & 11 & 26 & 53 & 66 & 28 \\
\hline Turkey & 3 & 1 & 28 & 49 & 34 \\
\hline Euro Area & n.a. & n.a. & 12 & 43 & 446 \\
\hline Poland & -1 & 9 & 11 & 40 & 42 \\
\hline Greece & 5 & 6 & 14 & 38 & 44 \\
\hline Italy & 8 & -5 & 21 & 38 & 82 \\
\hline Romania & 1 & 2 & 12 & 29 & 26 \\
\hline France & -3 & -32 & 24 & 27 & 143 \\
\hline Australia & 13 & 16 & 43 & 21 & 45 \\
\hline Mexico & 16 & 23 & 11 & 21 & 25 \\
\hline South Africa & 1 & 2 & 8 & 21 & 13 \\
\hline Bulgaria & 0 & 1 & 5 & 19 & 17 \\
\hline Vietnam & 3 & 1 & 3 & 18 & n.a. \\
\hline Colombia & 2 & 2 & 2 & 10 & 9 \\
\hline Hungary & 2 & 4 & 11 & 10 & 19 \\
\hline Peru & 2 & 2 & 1 & 9 & 8 \\
\hline Korea & 10 & 3 & 13 & 9 & -51 \\
\hline Argentina & 7 & 4 & -5 & 4 & -13 \\
\hline Philippines & 5 & 3 & 0 & 4 & -5 \\
\hline Indonesia & 7 & -5 & 0 & 3 & -2 \\
\hline Israel & 1 & 3 & -8 & -2 & 10 \\
\hline Thailand & 13 & -8 & 4 & -2 & 13 \\
\hline Chile & 3 & 2 & -1 & -9 & 12 \\
\hline Malaysia & 6 & -3 & -5 & -11 & n.a. \\
\hline Canada & 8 & -6 & -24 & -18 & -11 \\
\hline Singapore & -2 & -11 & -13 & -18 & n.a. \\
\hline China,P.R.:Hong Kong & n.a. & -6 & -21 & -20 & 4 \\
\hline Venezuela, Rep. Bol. & -1 & -2 & -13 & -23 & -26 \\
\hline Netherlands & -9 & -9 & -42 & -29 & -34 \\
\hline Switzerland & -16 & -30 & -61 & -30 & -45 \\
\hline Norway & -1 & -10 & -30 & -31 & -88 \\
\hline Kuwait & 7 & -7 & -28 & -38 & -59 \\
\hline Saudi Arabia & 11 & -3 & -66 & -89 & n.a. \\
\hline Japan & -68 & -77 & -33 & -187 & -173 \\
\hline Germany & 15 & -6 & -153 & -325 & -299 \\
\hline
\end{tabular}

Note: Countries have been arranged in descending order on the basis of net capital flows received during 2007. Data in columns 2 to 4 are annual averages for the respective periods.

Source: International Financial Statistics Online, IMF (Downloaded September 16, 2009). 
Annex 5

\section{Supervisory Responsibilities: Cross-Country Practices}

According to an IMF survey which covered 140 supervisory agencies in 103 countries, the majority of the participants (85 agencies or 60 per cent of total) are unitary agencies (i.e., agencies dedicated solely to the supervision of a single segment of the financial sector, not combined with any other agency and not responsible for supervising multiple types of financial entities) (Seelig and Novoa, 2009). The second largest group is represented by 'integrated supervisors' with a share of 23 per cent. (Integrated supervisors supervise combinations of any two-types of financial intermediaries, i.e., banks and insurance companies, banks and security firms, and insurance and security firms). Only 13 percent of the participants are single, fully consolidated supervisors (e.g., FSA in the UK), who oversee the entire financial sector (banks, insurance and security firms. In this context, a recent IMF survey finds that central banks dominate other agencies in terms of responsibility for banking supervision. Other supervisors (insurance and securities) typically tend to be standalone agencies. Out of 18 cases of consolidated supervision, four are with the central bank (Annex Table 3) 
Annex Table 3: Location of Supervisory Agencies: Cross-Country Survey

\begin{tabular}{|c|c|c|c|c|c|}
\hline \multirow{3}{*}{$\begin{array}{l}\text { Nature of } \\
\text { Supervisory } \\
\text { Responsibility }\end{array}$} & \multirow{2}{*}{\multicolumn{5}{|c|}{$\begin{array}{l}\text { (Number of Agencies) } \\
\text { Sunervisorv Agency Lated in }\end{array}$}} \\
\hline & \multicolumn{3}{|c|}{ Supervisory Agency Located in } & & \\
\hline & $\begin{array}{r}\text { Department } \\
\text { in Central } \\
\text { Bank }\end{array}$ & $\begin{array}{r}\text { Department } \\
\text { in Ministry } \\
\text { of Finance }\end{array}$ & $\begin{array}{r}\text { Separate } \\
\text { Agency }\end{array}$ & Others & Total \\
\hline 1 & 2 & 3 & 4 & 5 & 6 \\
\hline $\begin{array}{l}\text { Only Banking } \\
\text { Supervision }\end{array}$ & 25 & 2 & 10 & 7 & 44 \\
\hline $\begin{array}{l}\text { Only Insurance } \\
\text { Supervision }\end{array}$ & 2 & 3 & 9 & 2 & 16 \\
\hline Only Securities & 1 & 1 & 23 & 0 & 25 \\
\hline Supervision & & & & & \\
\hline $\begin{array}{l}\text { Consolidated } \\
\text { Supervision }\end{array}$ & 4 & 0 & 13 & 1 & 18 \\
\hline $\begin{array}{l}\text { Integrated } \\
\text { Supervision }\end{array}$ & 10 & 3 & 17 & 2 & 32 \\
\hline Others & & & & 5 & 5 \\
\hline Total & 42 & 9 & 72 & 17 & 140 \\
\hline
\end{tabular}

Source: Seelig and Novoa (2009). 
Annex 6

\section{Financial Crisis and Impact on Growth}

Financial crises have not only a short-term but also persistent and long-lasting adverse impact on output levels. In this context, the experience of the East Asian economies following the financial crisis is illustrative of such losses. In all these economies, the level of real output today is significantly lower than the case had there been no crisis. In Korea and Thailand, the levels of per capita real output in 2004 (seven years after the crisis) were 22 per cent and 56 per cent, respectively, below the levels had these economies continued to grow at the rate they had been growing in the decade prior to the crisis (Annex Chart 2) (IMF, 2009c).

In the case of all the East Asian economies, investment rates as well real growth rates remain substantially below their pre-crisis levels. For instance, real GDP growth in Korea and Thailand during 2003-07 averaged 4.3 per cent and 5.6 per cent, respectively, as compared with averages of 7.9 per cent and 8.6 per cent during the pre-crisis period (1990-96). Investment rates in these two economies fell from 38.9 per cent (of GDP) and 41.8 per cent in 1996, just before the crisis, 29.4 per cent and 26.8 per cent in 2007. Thus, significant declines in investment and growth rates can be a consequence of a financial crisis, which accumulate to large losses in output levels. 


\section{Annex Chart 2: Impact of East Asian Crisis on Growth}
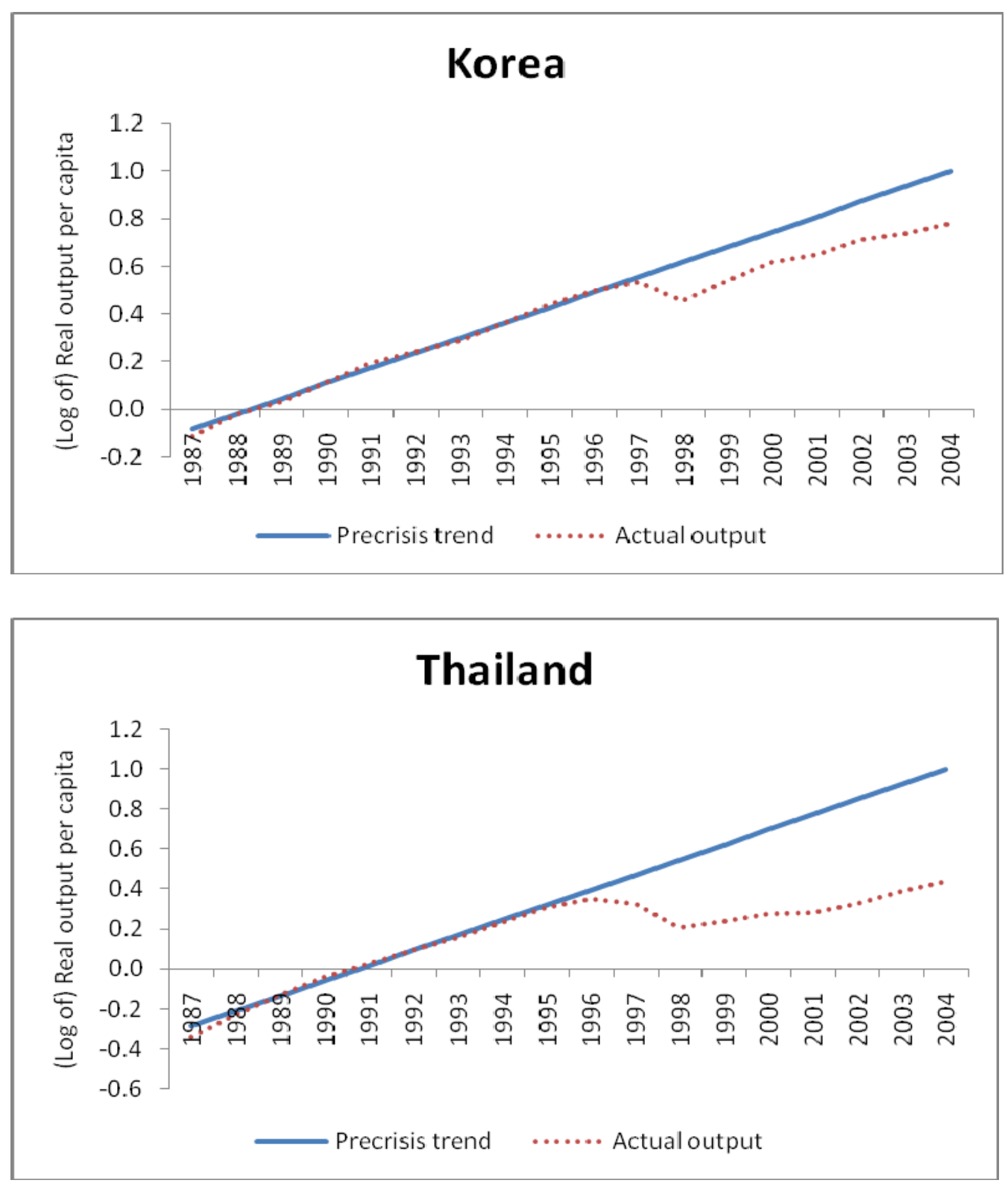

Source: IMF (2009c). 